\title{
Encontros Provisórios: Exercícios de Autoria Colaborativa com Base na Imagem Fotográfica
}

Dissertação apresentada ao Programa de PósGraduação em Artes Visuais, Área de Concentração Poéticas Visuais, Linha de Pesquisa Multimeios, da Escola de Comunicações e Artes da Universidade de São Paulo, como exigência parcial para obtenção do Título de Mestre em Artes, sob a orientação da Prof. Dra. Silvia Laurentiz.

Apoio FAPESP

São Paulo

2010 


\title{
CLAUDIA SANDOVAL ROMERO
}

\section{Encontros Provisórios: Exercícios de Autoria Colaborativa com Base na Imagem Fotográfica}

\author{
Dissertação apresentada ao Programa de Pós- \\ Graduação em Artes Visuais, Área de Concentração \\ Poéticas Visuais, Linha de Pesquisa Multimeios, da \\ Escola de Comunicações e Artes da Universidade de \\ São Paulo, como exigência parcial para obtenção do \\ Título de Mestre em Artes, sob a orientação da Prof. \\ Dra. Silvia Laurentiz.
}

Apoio FAPESP

São Paulo

2010 
Agradeço muito à Professora Doutora Silvia Laurentiz, minha orientadora, por ter me permitido crescer de seu lado.

À FAPESP porque foi o apoio desta instituição que potenciou a pesquisa.

Sou muito grata igualmente aos meus professores Gilbertto Prado, Julia Scher, Susanna Schoenberg, Martina Mrongovius, Mischa Kuball, Mônica Tavares, Antoni Muntadas, Ana Tavares, Martin Grossman, Artur Matuck e Arlindo Machado, assim como à Stella e a Regina da secretaria.

À minha família na Colômbia, à minha nova pequena família de seres muito queridos no Brasil e principalmente ao meu marido, porque todos eles e elas me dão a força para fazer as coisas com mais amor e alegria. 
Encontros Provisórios: Exercícios de Autoria Colaborativa com Base na Imagem Fotográfica questiona a figura do autor nos trabalhos de arte colaborativa para a internet. A proposta analisa o caso da imagem fotográfica como base para este tipo de criação virtual. Faz igualmente uma aproximação crítica à figura do autor da internet em relação ao contexto e apresenta finalmente uma série de trabalhos práticos como conclusões do percurso teórico.

Palavras-chave: Web arte, Net.art, Fotografia, Criação Colaborativa, Internet, Arte e contexto, Autoria. 
Provisory Encounters: Collaborative Authorship Exercises Based on the Photographic Image inquires the author's role in collaborative art pieces for the internet. The proposal examines the case of photographic image as a base for this type of virtual creation. Makes at the same time a critical approach to internet's author role in relation to the context and finally presents a series of practical works as conclusions of the theoretical one.

Key words: Web art, Net.art, Photography, Collaborative Creation, Internet, Art and Context, Authorship. 
Capítulo I: Algumas problemáticas da autoria, a rede e a arte da Internet

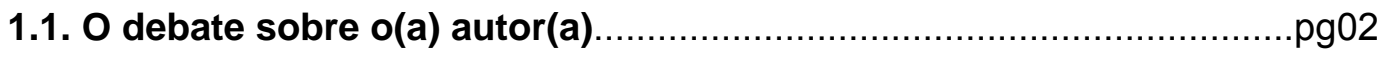

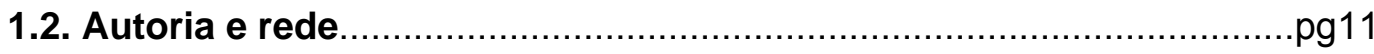

1.3. Algumas problemáticas da arte da web......................................pg18

1.4. Algumas referências críticas sobre a arte das NTC e as

fronteiras .$p g 23$

Capítulo II: Algumas questões da imagem fotográfica digital

2.1. Algumas questões da imagem fotográfica....................................pg29

2.2. Aproximação aos usos sociais da fotografia digital .......................pg33

2.3. Criação colaborativa da imagem fotográfica: alguns casos brasileiros

2.3.1. Fernando Tacca, Big Brother (2001) ........................................pg 36

2.3.2. Nardo Germano, Doe seu Rosto (2001-2006) e Andromaquia (20042006) .pg39

2.3.3. Fernando Velásquez, O Colecionador de Espíritos (2003) .............pg42

2.3.4. Kiko Goifman e Jurandir Muller, Cronofagia (2002) ......................pg 44

Capítulo III: Work in Progress

3.1. Propostas colaborativas desenvolvidas com base na fotografia: Cicatrizando (2006-2009), Living Cemetery (2008-2009) e Desaparecidos (2009) .pg47

3.2. Propostas ao redor da fotografia. Passport (2008) Ovo (2009)..........pg56

3.3. Propostas ao limite da fotografia. Coyote (2009), Caloto (2009) e Sammlung (2010).

3.4. Propostas locais em ambientes internacionais. Lost Memories (2010) e Holograms of Deportation (2010). .pg69

\section{Considerações Finais}

I Desconstrução da autoria e desautorização do(a) autor(a)...................pg77

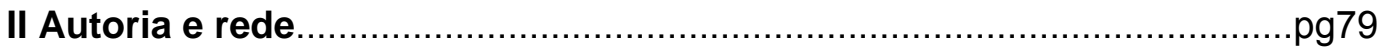

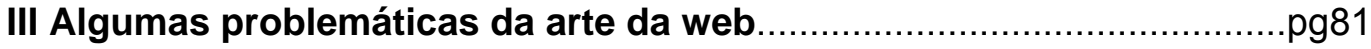

IV Algumas referências críticas sobre a arte das NTC e as fronteiras.....pg83 


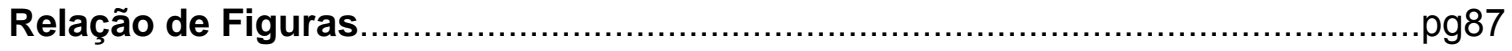

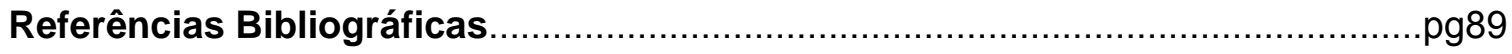

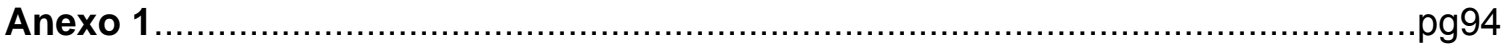




\section{Introdução}

Em Encontros Provisórios: Exercícios de Autoria Colaborativa com Base na Imagem Fotográfica indagamos sobre a autoria no ambiente comunicacional da Internet.

Desenvolvemos um primeiro capítulo sobre algumas problemáticas da autoria, a rede e a arte da Internet. Fizemos assim, uma compilação sucinta de diversas posições que compõem o debate sobre a autoria. A aproximação à noção de "autoria" compreendeu posições sobre a desaparição de tal figura nas criações colaborativas, assim como também abrangeu outras noções em que o autor é ainda imprescindível para a criação artística em coletivos. Da mesma maneira, incluímos a discussão de algumas problemáticas da arte para a Internet, dando ênfase a uma posição autoral por nós defendida que considera a América Latina e suas particularidades no momento da criação em ambientes homogenizantes como a Internet.

Algumas das questões da imagem fotográfica digital foram apresentadas no segundo capítulo, pois a fotografia digital é a base para nossas experimentações. $O$ trabalho aqui apresentado levanta igualmente questões sobre as mudanças sofridas pela imagem fotográfica quando usada como base na criação de peças para a Internet.

No terceiro capítulo, apresentamos questões relacionadas ao processo criativo em si, a partir dos trabalhos experimentais artísticos desenvolvidos durante este período que retroalimentavam as reflexões envolvidas nesta dissertação. Em Encontros Provisórios nos propusemos desenvolver uma série de exercícios práticos tendo como objetivo estabelecer um contato com o outro, isto é, quisemos criar pontos de encontro com um 'outro' tão necessário na criação colaborativa. Queríamos partir da premissa de Antoni Muntadas, para quem "os trabalhos são sempre autobiográficos" (2007:122) para criarmos nossas próprias "revoluções moleculares" (GATTARI apud MACHADO, 2007:57). Micro-revoluções estas que aqui apresentamos com a esperança de que sejam de valor para outros autores e autoras deste e de outros contextos.

Por último, apresentamos algumas considerações finais. 


\section{Capítulo I: Algumas problemáticas da autoria, a rede e a arte da Internet}

\subsection{O debate sobre o(a) autor(a)}

O debate sobre o lugar que ocupa o autor nos produtos culturais tem sido assunto de discussão em diversos momentos da história desde a produção literária até o momento atual da criação para a Internet. Faremos aqui uma breve análise sobre a atividade da autoria a partir de alguns autores, apoiados em textos impressos e/ou em hipertexto/multimídia criados em comunidades virtuais com o uso da Internet. Procuraremos assim pelas implicações da questão da figura do autor hoje, questionando se devemos ou não retomar a ideia da (des)aparição do autor e quais as consequências sócio-políticas da figura autoral no contexto atual.

Antoine Compagnon (2001:49-50) já demonstrou como uma das controvérsias da literatura tem sido a posição do autor em relação ao significado de sua obra, refletindo sobre a célebre conferência ministrada por Michel Foucault em 1969, intitulada "O que é um autor?", que teria acontecido aparentemente como resposta a Roland Barthes, que tinha publicado um artigo em 1968 cujo título era "A morte do autor". A questão da morte do autor de Barthes referia-se à perda de importância do mesmo na interpretação do texto, isto é, o autor como um indivíduo com certo prestígio e de cuja produção se desprende o sentido, não podendo significar outra coisa que não o que este autor produziu: "a explicação da obra é sempre procurada do lado de quem a produziu como se, através da alegoria mais ou menos transparente da ficção, fosse sempre afinal a voz de uma só e mesma pessoa, o autor, que nos entregasse a sua «confidência»" (BARTHES apud COMPAGNON, 2001:50).

Compagnon (2001:50-51) esclarece que para Barthes o autor era sinônimo de burguês, o produto por excelência da ideologia capitalista e que, por este motivo, teve de ser liquidado para dar novos sentidos à interpretação. Deste modo, Barthes desligou a explicação do texto da biografia e da intenção do autor, já que a intenção do autor, segundo Barthes, não podia restringir a riqueza do texto.

Barthes substitui o autor como princípio produtor e explicativo da literatura pela linguagem impessoal e anônima, cedendo o lugar principal à escritura, ao texto: "O autor alimenta o livro, quer dizer que existe antes dele, pensa, sofre, vive com ele; tem

\footnotetext{
${ }^{1}$ Com fins práticos ao longo do texto, quando se fale de termos como "Autor" e "Artista" de maneira geral, estaremos fazendo referência tanto ao gênero masculino quanto ao feminino "Autora" e "a Artista".
} 
com ele a mesma relação de antecedência que um pai mantém com o seu filho" (BARTHES apud COMPAGNON, 2001:50).

Já Foucault em "O que é um autor?" (1969) define a função do autor como critério da interpretação: sem o autor o texto ficaria sem as referências iniciais para que o leitor conseguisse interpretá-lo.

Foucault se pergunta por esse autor e por sua "função", apresentando, tal como Barthes, a crise da figura do autor em relação ao contexto político da época (a Europa de finais da década de sessenta). Para Foucault o autor é uma construção histórica e ideológica que serve no tratamento "psicologizante" que se dá ao texto, questão que redundou numa polissemia mesma do texto. O teórico então se questionava se essa morte do autor não consistia numa troca - o leitor como substituto do autor (apud COMPAGNON, 2001:52) - enfatizando a importância não da discussão sobre a morte ou não da figura autoral, mas da procura das lacunas que a ausência de uma forte presença autoral deixou, e, assim, as funções livres que surgiram dessa desaparição (FOUCAULT, 1969:92-93).

Décadas depois, o lugar reservado ao autor nas criações artísticas é ainda alvo de debate, apontando novas maneiras em que o autor parece novamente desaparecer, agora dentro do contexto da criação hipertextual. Neste contexto as funções escritorleitor tornam-se mais profundamente entrelaçadas e como nunca antes, fazendo com que o papel do emissor se desvaneça, espalhando-se na inter-relação com os receptores. Esta transformação de fusão máxima é o último estágio na convergência do que alguma vez foram duas atividades muito diferentes. Para George P. Landow (1992) "a posição do autor se acha tão disseminada na atualidade, que podemos imaginar facilmente uma cultura na qual o discurso circule livremente sem que se necessite da existência de autor algum" (LANDOW, 1992:80).

Ideias fundamentais para o teórico são as mudanças que a figura do autor tem sofrido a partir dos novos modos de aproximação textual. Essa nova textualidade carece de um centro. Isso faz com que se disperse o autor, demolindo o que conhecemos como autoria única, "removendo assim a autonomia do texto, descentrando-o e transformando-o em uma rede" (LANDOW, 1992:71). Deste modo, para Landow, a nova autoria dos ambientes hipertextuais é ao mesmo tempo dispersa e colaborativa e aparece ao comparar os papéis escritor-leitor. Nas dinâmicas cada vez mais ativas de participação do leitor através de propostas aos autores do hipertexto, as 
quais consistem nas escolhas que o leitor ou leitora faz, a desaparição da fronteira dos papéis autor-leitor permite que se fortifique a autoria colaborativa (LANDOW, 1992:88).

Para Landow os sistemas hipertextuais oferecem ao leitor e ao escritor o mesmo ambiente compartilhado. No momento da publicação do texto citado (1992) o teórico reconhecia que sistemas como "Hypercard" e "Guide" ofereciam as primeiras aproximações à hipertextualidade em maior grau comparado ao livro impresso (LANDOW, 1992:7). Cabe perguntar se a Internet hoje constituiria o ambiente que Landow previa como completamente hipertextual, isto é, o local em que autor e leitor compartilham as mesmas condições e entram em contato, aproximando-se da desaparição das figuras autor-leitor.

Landow atualiza a ideia do entrelaçamento das figuras escritor-leitor em mídias de comunicação atuais, sendo que Barthes, entre outros autores, tratou em 1970 da questão do desvio da função escritor-leitor, apontando para a importância do leitor como figura que dá sentido na literatura: "no texto, fala apenas o leitor" (1970:173).

A escritura é ativa, pois age em benefício do leitor: procede, não de um autor, mas de um escritor público, notário encarregado pela instituição, não de agradar seu cliente, mas de consignar, mediante ditado desse cliente, a lista de seus interesses, as operações pelas quais, no interior de uma economia da revelação, administra esta mercadoria: a narrativa (BARTHES, 1970:174)

A pluralidade de sentidos atualizada para os ambientes hipertextuais por Landow (1992) já fora também pensada por Barthes, em 1970, na impossibilidade de atribuir à enunciação uma origem, fazendo mais plural o texto moderno ao compará-lo com o texto clássico em que na maior parte dos enunciados pode lhes identificar "o pai e proprietário" (BARTHES, 1970:73)².

Em Barthes, o alvo do trabalho literário é fazer o leitor não mais um consumidor com a pobre liberdade de aceitar ou rejeitar o texto, mas um produtor do texto. Landow (1992:4) reconhece que Barthes e Foucault, como quase todos os estruturalistas e pósestruturalistas, descrevem no texto, isto é, no mundo das letras, uma discussão que será radicalmente potencializada pelos ambientes hipertextuais posteriormente.

A análise de Landow (1992) parte do fato de que nas décadas anteriores à publicação de Hypertext, a teoria literária e o hipertexto computacional, aparentemente

2 Quem fala na frase "A primeira vez que apareceu na mansão foi durante um concerto e parecia ter sido atraído para o salão pela encantadora voz de Marianina"? (BARTHES, 1970:74). Na literatura moderna desaparece o enunciador, fazendo com que, segundo Barthes, o texto ganhe em pluralidade. 
duas áreas com questionamentos isolados, aumentaram sua convergência. Assim, sua teoria baseia-se nos paradigmas sugeridos por Jacques Derrida e Theodor Nelson, assim como Roland Barthes e Andries van Dam. Esses quatro autores, como tantos outros vindos da computação e da teoria e crítica cultural e literária, argumentam que devemos abandonar os sistemas edificados em ideias de centro, margem, hierarquia e linearidade, substituindo-os pelos de multilinearidade, nós, links e redes (LANDOW, 1992:1-2).

Como Landow, Janet Murray, em 1997, faz uma análise do momento presente de criação hipertextual, expondo como o futuro da narrativa no ciberespaço será encarregada por um autor procedimental, isto é, como aquele que "trata de antecipar todas as reviravoltas do caleidoscópio, todas as ações do interator, e especificar não apenas os acontecimentos do enredo, mas também as regras sob as quais esses eventos ocorrerão" (MURRAY, 2001:178). Para Murray, os autores do ciberespaço, assim como os escritores, "precisarão de um método concreto para estruturar uma história coerente, não como uma sequência isolada de eventos, mas como um enredo multiforme aberto à participação colaborativa do interator" (MURRAY, 2001:179).

Para a autora, o computador é essencialmente uma ferramenta procedimental já que não observa ou descreve padrões de comportamento, mas os incorpora e executa: "como meio participativo que é, ele permite que colaboremos com a performance" (MURRAY, 2001:178-175). Desta maneira, a autoria procedimental significa tanto escrever as regras pelas quais os textos aparecem nos ambientes virtuais, quanto escrever os próprios textos (MURRAY, 2001:149). Tais regras são mecanismos de envolvimento do interator; são condições de resposta às ações dos participantes. São ao mesmo tempo propriedades dos objetos e seus potenciais, assim como suas fórmulas de relação: "O autor procedimental não cria simplesmente um conjunto de cenas, mas um mundo de possibilidades narrativas" (MURRAY, 2001:149).

Diferente de Landow (1993) com os estruturalistas, pós-estruturalistas e teóricos do mundo da computação por ele citados, Murray dá ênfase ao fato de que o interator não é o autor da narrativa digital, "isso não é autoria, mas agência" (MURRAY, 2001:149), ainda que existam outros níveis de autoria no interior das propostas participativas:

O interator é o autor de uma performance em particular dentro de um sistema de história eletrônico, ou o arquiteto de uma parte específica do mundo virtual, mas precisamos 
distinguir essa autoria derivativa da autoria original do próprio sistema. (MURRAY, 2001:149-150)

Para Claudia Giannetti, as novas tecnologias promovem a emergência de comunidades que tendem cada vez mais à auto-organização e dentro das quais o artista sofre uma consciente perda de controle sobre a obra, já que concede a responsabilidade de ação ao usuário que intervém no sistema (GIANNETTI, 2006:94).

Alguns autores como Pierre Lévy (1993) não vêem grandes mudanças na figura do autor no contexto da criação contemporânea, apontando o fato de que:

O autor é a condição de possibilidade de qualquer horizonte de sentido estável. Mas tornou-se banal dizer que a cibercultura coloca muito em questão a importância e a função do signatário. O engenheiro de mundos não assina uma obra acabada, mas um ambiente por essência inacabado, cabendo aos exploradores construir não apenas o sentido variável, múltiplo, inesperado, mas também a ordem de leitura às formas sensíveis (LÉVY, 1993:147-148).

Para Lévy, as mudanças das obras nos meios virtuais modificam a posição do autor como produtor de sentido, sendo que intérpretes - ou performers -, exploradores e engenheiros, isto é, os membros da equipe de produção, são cada vez mais importantes na constituição do sentido de tais obras, do que propriamente o autor. Esse autor se faz então, um autor cada vez menos discernível.

Ao mesmo tempo, considerando-se o novo sentido como aberto ou polissêmico, devemos continuar a acreditar na existência de um autor se queremos extrair dos trabalhos virtuais intenções, isto é, "interpretar um projeto, uma expressão social ou mesmo um inconsciente" (LÉVY, 1993:148). No entanto, a importância do autor como gênio, isto é, como criador absoluto, dono da estrutura comunicativa dentro da cibercultura, se transforma em um item a mais e com menor importância em relação à produção em si.

Não creio que, após ter passado por um estado de civilização no qual o arquivo memorável e o gênio criador sejam tão presentes, possamos imaginar (salvo em caso de catástrofe cultural) uma situação na qual o autor tenha desaparecido totalmente. Em contrapartida, devemos antever um estado futuro da civilização no qual esse ferrolho da totalização em declínio teria apenas um pequeno lugar nas preocupações daqueles que produzem, transformam e apreciam as obras do espírito (LÉVY, 1993:151). 
Em contraposição às mensuradas ideias de Pierre Lévy sobre a não-morte do autor, mas sobre a perda de sua importância, Roy Ascott (2003) não teme, por sua vez, decretar uma morte do autor nos ambientes telemáticos.

O processo telemático, juntando por satélite, cabo, e fios de fibra ótica, uma vasta diversidade de entradas mundiais, celebra a morte do autor de imagens e textos "individuais" e "originais"; e traz à vida, em troco, um novo "autor disperso" - e interconectado, distribuído - gerando uma variedade massiva de autores, ao interior da "imaterialidade" virtual das redes. O desvanecimento da ideia de um autor só e original cede seu lugar à ideia da autoria múltipla [...] que se dá através das interações ou colaborações de múltiplos usuários dispersos pelos sistemas em rede (ASCOTT, 2003:209).

Segundo Ascott (2003:81) o momento atual da produção da arte, com seu relativismo de realidades que se misturam se sobrepondo, somado às mudanças nos códigos de pertencimento social, prepararam-nos para mudanças em torno das noções de autoridade, autoria e propriedade de ideias. A figura do autor é substituída pela da Consciência Global, onde não existem indivíduos juntando seus saberes, mas uma rede que fusiona ideias e imagens em fluxo constante e dentro das quais não é possível atribuir uma autoria. A impossibilidade de estabelecer uma autoria se desprende da participação daquele que interage numa estrutura sem centro nem hierarquia. A impossibilidade de atribuir a um autor às criações das novas propostas comunicacionais denota outra dificuldade: a da propriedade individual (ASCOTT, 2003:81).

Temos até aqui caracterizada a complexidade do debate da figura autoral do ponto de vista da criação. Outras propostas, como a Estética da Recepção (JAUSS, 1993), partem em direção contrária da que analisamos até o momento. Hans Robert Jauss (1993) fala de um autor que não tem se desvanecido, mas cuja sua função se desprende da relação com o interator. Na sua Estética da Recepção uma obra de arte só se concretiza quando um leitor a legitima como tal. O trabalho do autor é então relegado a um plano secundário e o que interessa é o produto criado após o convite, o resultado da criação em rede, a forma final plural. O importante para esse tipo de autoria depende do ato comunicativo com o outro através das propostas.

A posição de Jauss (1993) da Estética da Recepção é considerar que o autor prioriza a resposta do espectador e assim lhe oferece o estatuto mais importante da criação. Esse autor encontra eco nas ideias de Murray (2001) que se refere ao autor procedimental ou aquele que se vale das performances individuais dos interatores, já que sem elas sua obra não acontece. Assim como Giannetti (2006:94) reconhece que a 
obra dentro de ambientes interativos concede a responsabilidade de ação ao usuário que intervém no sistema, e concorda também com Barthes (1970:174) ao declarar o escritor como um funcionário público consignando ao leitor o quer que seja escrito.

A partir de outra perspectiva, André Lemos (2002) faz referência a Marshall McLuhan, asseverando que Gutenberg nos fez leitores, já a máquina Xerox, os editores, e os computadores em rede nos fazem autores. Assim, na construção hipertextual do ciberespaço um dos perigos consiste em todos sermos autores, o que equivale a dizer que ninguém é um autor, fato este advindo das diferenças inexistentes entre as figuras de autor e leitor (WOLLEY apud LEMOS, 2002). A esse respeito, ao se tratarem de fenômenos de negação do autor, manifestações como os blogs libertam a autoria em prol de uma comunicação mais abrangente, reflete Lemos (2002):

O "meu nome é ninguém" é uma forma de escapar dos cânones da arte e da ciência. Esta banalidade permite que "ninguém" (ou seja "todo mundo") possa ser ouvido (e) faz dessas experiências algo interessante sob o ponto de vista social, político e comunicacional (LEMOS, 2002).

A crise sofrida pelos acadêmicos gregos que em 1930, segundo a história citada por Janet Murray (2001:150), descobriram um Homero não original que reunia frases feitas e unidades narrativas predefinidas, subsiste hoje nas criações coletivas. Queremos um 'Autor' e ainda estamos à procura de sua genialidade e caráter único no contexto contemporâneo da arte feita em redes virtuais como a Internet. Precisamos do 'Autor' porque insistimos em acreditar na 'Arte', as duas em maiúsculo, assim como demandamos sua existência quando procuramos pelos responsáveis dos conteúdos, segundo confirma Giselle Beiguelman (BEIGUELMAN, 2008).

A discussão sobre a posição do autor no momento contemporâneo remete ao debate da pertinência do debate mesmo. Por ter sido este um assunto amplamente discutido, a teórica Silvia Laurentiz menciona outra perspectiva:

Estamos atolados de referências sobre o tema da subjetividade e as novas tecnologias de comunicação e informação. Roy Ascott denomina um eu "individual distribuído"; Zielinski acredita no "particular e heterogêneo", e para ele a subjetividade da rede traria a possibilidade de uma "ação em fronteiras"; Lévy nos fala de uma "subjetividade plural" e em "categorias de sujeitos"; Mario Costa desenvolve a noção de um "hipersujeito planetário"; e Couchot nos fala ainda de um "sujeito interfaceado" (LAURENTIZ, 2006).

Mesmo que a questão da autoria tenha sido amplamente tratada, parece que é necessário voltarmos ao debate para assumir uma nova perspectiva em relação ao 
labor do artista da rede virtual Internet. Voltarmos então ao debate sobre a figura autoral, não para que essa desapareça, mas para retomá-la de maneira que se efetive através de outro olhar. $O$ autor de que falamos não acaba, mas é um autor diferente. Ele é parte constitutiva da proposta artística. É um autor procedimental (MURRAY, 2001) que fala de perspectivas locais e pessoais, ainda que suas propostas sejam pensadas para serem construídas em coletivo. Sua proposta é uma mistura com outras autorias como a que emerge da "consciência global" (ASCOTT, 2003), ou da "inteligência coletiva” (LÉVY, 1993) na qual o autor é uma comunidade. É como se neste tipo de autoria tal "consciência global" tivesse tomado forma no mundo.

Esta perda de importância chamada "morte do autor" (ASCOTT, 2003 e LANDOW, 1992), tanto como a discussão sobre o assunto, está ultrapassadas por se comprovar que não existe uma geração espontânea de produtos culturais, e sim a existência de um autor que dirige as propostas, mesmo que seja sutilmente. Não obstante, pede-se a volta ao debate da figura autoral para que se amplie a problematização de seu labor nas criações colaborativas contemporâneas na Internet. Levando sua atitude compromissada ao limite de se tornar cada vez menos importante, em prol da comunidade que convida a participar de seus projetos, propõe-se um autor que se desautorize a si mesmo, que desconstrua sua própria figura autoral. Procura-se, assim, obter os benefícios da criação de propostas coletivas feitas na rede Internet que sejam cada vez mais horizontais. Benefícios estes que provêm da criação colaborativa nas redes virtuais, e que se torna possível se os autores deste contexto assumem a importância da diluição de sua figura no grupal e colaborativo, na aproximação crítica a seu próprio trabalho.

Pede-se a volta ao debate sobre a figura do autor, mesmo parecendo desgastado (LAURENTIZ, 2006) para ressaltar que o autor dos sistemas colaborativos carrega a responsabilidade da negação de si próprio, para permitir a participação de uma comunidade. Isto repercute na emergência de aproximações aos modos como se faz arte, saindo também da base do sensível individual e focando-se num compromisso com a representação do sensível coletivo.

Um autor "disperso", "enfraquecido" e até "morto" (ASCOTT, 2003 e LANDOW, 1992) soa mais como uma utopia intelectual do que como uma prática de hierarquia horizontal facilmente acessível e implementável. $\mathrm{Na}$ prática, em criações contemporâneas o autor ainda continua latente e forte, não só pelas limitações da proposta de interatividade, limites existentes a despeito da sofisticação do modelo de 
resposta, como também porque é só e tão somente por este autor que a obra acontece. O autor que propõe o trabalho, mesmo estando presente só no momento inicial, coordena assim o trabalho. Este autor é responsável até pela autonomia mesma do trabalho. É esta a posição com a que experimentamos nos projetos práticos que apresentaremos no terceiro capítulo. 


\subsection{Autoria e rede}

Faremos uma aproximação, neste momento, do conceito de rede trazendo anotações da teoria literária ao hipertexto ou criação colaborativa nas redes sociais virtuais como a Internet. A partir desta análise procuraremos aprofundar a relação redepráxis do trabalho coletivo, apontando para os cuidados com que o conceito de rede deve ser construído.

No livro S/Z (Barthes,1970) se descreve uma textualidade ideal que encaixa no que se chamou posteriormente de hipertexto computacional ou texto composto de blocos de palavras ou imagens, segundo analisa posteriormente Landow (1992:3). Estes blocos se conectam eletronicamente hoje por múltiplas rotas, cadeias, e pistas, em uma textualidade aberta e perpetuamente inacabada, descrita em termos de link, nó, rede, web, e caminho.

Nesse texto ideal, as redes são múltiplas e se entrelaçam, sem que nenhuma possa dominar as outras; este texto é uma galáxia de significantes, não uma estrutura de significados; não tem início; é reversível; nele penetramos por diversas entradas, em que nenhuma possa ser considerada principal; os códigos que mobiliza perfilam-se a perder a vista, eles não são dedutíveis...; os sistemas de sentido podem apoderar-se desse texto absolutamente plural, mas seu número nunca é limitado, sua medida é o infinito da linguagem (BARTHES, 1970:39-40).

Landow (1992) relaciona as ideias de Barthes com as de Foucault, já que Foucault também concebe o texto em termos de rede e links. Na Arqueologia do Conhecimento, Foucault pontua que as fronteiras do livro nunca são cortes claros porque "é capturada em um sistema de referências a outros livros, outros textos, outras frases: é um nó numa rede... uma rede de referências" (LANDOW, 1992:4).

Uma contextualização histórica do termo "hipertexto" feita por Landow explica que o termo foi acunhado por Theodor $\mathrm{H}$. Nelson em 1960 e que faz referência a forma do texto eletrônico, a uma tecnologia de informação radicalmente nova e a um modo de publicação. Por hipertexto, explica Nelson, "quero dizer escrita não-seqüencial; texto que se ramifica e permite escolhas ao leitor e com melhor leitura numa tela interativa. Como é popularmente conhecido, é um texto que oferece diversos caminhos ao leitor" (apud LANDOW, 1992:4). Hipertexto denota um texto composto por blocos de texto, blocos que eram denominados como "lexia" em Barthes, que se juntam eletronicamente a um texto maior. Hipertexto e hipermídia são então termos equivalentes para o teórico, que não faz diferencia entre o tipo de material que pode se misturar para compor um 
texto final, seja tal material escrito ou que contenha informação não verbal (LANDOW, 1992:4).

Autores como Derrida, assim como Barthes, Foucault e Mikhail Bakhtin, usam continuamente os termos link, web, rede e entretecido. Mas em contraste com Barthes, que foca no legível do texto e sua não-linearidade, Derrida enfatiza a abertura do texto, a intertextualidade e a irrelevante distinção entre dentro e fora de um texto particular. Derrida em sua "metodologia de decomposição" concebe o texto como constituído por unidades de leitura discretas que se relacionam, assim como Barthes (apud LANDOW,1992:4) o fez nos "lexia".

O texto como rede aparece na ênfase na descontinuidade proposta por Derrida que concebe o hipertexto como um amplo "ensamble". A mesma ideia aparece em Landow nomeada como "metatexto", em Nelson chamada de "docuverso" e em Ulmer definida como a colagem/montagem linguística. O termo "ensamble" sugere que a junção tem a estrutura de uma rede coesa que possibilitaria uma leitura geral, produzida pelas diversas linhas interligadas umas às outras, mas que permitiria também as leituras isoladas de cada uma das diversas linhas que a compõem (LANDOW, 1992:8).

Landow aplica pontualmente as faculdades de leitura do texto descritas por Barthes às do hipertexto do cenário tecnológico de 1992: você tem a oportunidade de colocar textos, uns junto aos outros, num monitor de duas páginas gráficas, desta maneira você ativa o hipertexto, trazendo para a vista o equivalente a uma referência de fim de texto. O documento posto do lado ao texto lido aparece como independente e não como um texto secundário dele. A multiplicidade do hipertexto, que aparece como múltiples links de blocos individuais de texto, chama à leitura a um leitor ativo. No futuro, sistemas completamente hipertextuais oferecem a possibilidade de tomar notas ou escrever em contra do texto, ainda que não se possa mudar ele. Esta hipertextualidade permite fazer outras leituras diferentes às propostas pelo texto, como produto dos diferentes caminhos tomados pelo leitor (LANDOW, 1992:6-7).

Com as Novas Tecnologias Comunicacionais (NTC) como a Internet, o modo linear de criação que dirigia a informação a partir do artista ou de sua obra até o receptor é substituída pela distribuição do código em forma de agente, transformando os usuários em nós (nodes) de inter-relações e em agentes que multiplicam as ações (GIANNETTI, 2006). A existência dos agentes e dos usuários, enquanto nós, depende exclusivamente da comunicação de uns com os outros. Isso permite que se assuma de uma maneira nova e peculiar questões sobre o network e o sistema, assim como sobre 
sua estética, uma vez que as inscreve na reestruturação do modelo de sociabilidade até agora baseado, principalmente, no individualismo em rede (GIANNETTI, 2006:94).

A continuidade da obra, o que equivale a dizer a obra mesma dentro de ambientes interativos, depende da intercomunicação dos usuários e a geração mutável de uma "arquitetura flexível de contatos que expande a plataforma e cria sempre novas comunidades" (GIANNETTI, 2006:94).

De outra perspectiva, autores como Ascott (2003) declaram a importância da rede após reconhecer a "morte do autor". Colocando em questão as novas marcas e tendências de nosso ser em sociedade, aquele autor "morto" renasce, produto de sua fusão com o todo, sendo ele doravante não um sujeito em particular, mas as dinâmicas comunicativas da nova comunidade. O autor é assim uma "Consciência Global" que emerge a partir da apropriação globalizada das NTC.

O sentido está sendo criado na interação entre pessoas, mais do que sendo "algo" que se envia de um para outro. Se existe um autor deste "sentido", então ele deve ser o sistema de interação e devemos falar de uma "autoria dispersa", que abrange todos aqueles envolvidos na negociação de um sentido em um contexto determinado (ASCOTT, 2003:213).

A rede, desde a perspectiva positivista de Ascott (2003), é um sistema horizontal ${ }^{3}$ e holístico em que a agressão, a competição e o domínio ficam por fora na medida em que todas as partes se interconectam (ASCOTT, 2003:236).

Pierre Lévy (1993) esboça, por sua vez, uma teoria similar sobre a Inteligência Coletiva, descrevendo-a como uma consequência otimista da criação colaborativa, a partir do fato de que um grupo humano se constitui como comunidade virtual na procura de um coletivo que seja "mais inteligente, rápido e imaginativo" que não esteja organizado horizontalmente, mas "inteligentemente gerenciado" com o propósito de juntar saberes, e também "as energias espirituais daqueles que estão conectados a ele" (LÉVY, 1993:131).

Em relação à criação em rede, tal parece que não temos solucionado posições contraditórias sobre a maneira como estão empregando-se as capacidades dessa "Inteligência Coletiva". Derivadas de sua utilização, podemos intuir tanto a potência das faculdades humanas quanto, pelo contrário, predizer a paulatina implementação de cruas estratégias de exercício do poder, dominação sobre emergentes classes de

\footnotetext{
${ }^{3}$ O horizontal é a metáfora para o olhar que inclui tudo ao redor, para o inclusivo e a capacidade de abraçar tudo o que alcance o olhar (ASCOTT, 2003:236).
} 
marginados tecnológicos, e abusos na utilização do saber coletivo (MACHADO, 2007, TRIVINHO, 2007 e GARCIA DOS SANTOS, 2003).

Sobre a produção intelectual em rede, as perguntas têm sido postuladas sem que tenham sido respondidas cabalmente:

Trata-se de construir colmeias ou formigueiros humanos? Desejamos que cada rede dê à luz um grande animal coletivo? Ou o objetivo é ao contrário, valorizar as contribuições pessoais de um e colocar os recursos dos grupos a serviço dos indivíduos? A inteligência coletiva é um modo de coordenação eficaz na qual cada um pode considerar-se como um centro? Ou, então, desejamos subordinar os indivíduos a um organismo que os ultrapassa? O coletivo inteligente é dinâmico, autônomo, emergente, fractal? Ou é definido e controlado por uma instância que se sobrepõe a ele? (LÉVY, 1993:131).

Ascott (2003) e Lévy (1993) são essencialmente otimistas a respeito do uso das tecnologias como a Internet e posterior surgimento da "Inteligência Coletiva". Mas Lévy evidencia dúvidas sobre a criação coletiva, contrapondo-se ao constante positivismo de Ascott.

Steven Johnson (2003) por sua vez verá mais valor na comunicação entre indivíduos do que na produção de produtos específicos. O teórico interpreta a formação de uma inteligência emergente, coletiva, baseada nas "interações de diferentes indivíduos, muito mais do que por suas ações causais no contexto social" (apud LAURENTIZ, 2004).

Historicamente as origens desses entes aglutinantes foram analisadas por pensadores como Teilhard de Chardin nos anos 1920 com o advento do rádio e da televisão (apud COSTA, 1995). Para Mario Costa (1995) a importância antropológica das neotecnologias comunicacionais foi intuída por Chardin que falava já de um organismo humano planetário ao qual fazia referência como "ultra-humano" e que consistia num prolongamento do corpo humano individual.

$\mathrm{Na}$ atualidade o trabalho em rede permite a continuidade da obra, o que equivale dizer que a obra, mesmo dentro de ambientes interativos depende da intercomunicação dos usuários e da geração mutável de uma "arquitetura flexível de contatos que expande a plataforma e cria sempre novas comunidades" (GIANNETTI, 2006:94).

Nessa comunidade em rede que cria através da junção de 'outros', Gilbertto Prado ressalta:

O outro é também um espelho, ou mais ainda: um olhar crítico, um obstáculo a ser superado e/ou a partilhar, ou seja, um regulador dos intercâmbios. É a presença dos 
outros, vendo o que vemos, escutando o que escutamos, que nos assegura da realidade do mundo e de nós mesmos (PRADO, 1997).

Olhares distintos, coisas diversas e posições diferentes conformam nosso próprio universo dinâmico vivenciado no interior da rede, este é um universo possível construído nas trocas interativas. Um universo a mais dentre muitos outros (PRADO, 1997).

Silvia Laurentiz propõe o sentido de "nós mesmos (self)" relacionado à rede, já que existimos "porque possuímos a capacidade de 'interfacear' com o mundo. Eu estou 'em/para' interações que faço com o mundo, além das que realizo em mim mesmo. A proposta é que ambientes de rede passam por um processo similar" (LAURENTIZ, 2006).

Cabe aqui nos perguntar se podemos falar realmente de trabalho em coletivo potenciado pela rede ou se estamos dando muita importância ao estado em bruto da rede e às ações não calculadas dentro dela, como assegura Laurentiz:

Poderemos falar realmente do surgimento de uma "consciência planetária", evocada por Roy Ascott, considerando que esta consciência criada deve ter autocontrole, autolimitação, autoreferencialidade, que "seja capaz de dominar a si mesma"? Ou se trata de um estado bruto de consciência, uma "quase-consciência", que está sendo gerada pelo sistema e que pode através de uma ínfima brecha, "provocar coisas" que dela não se é esperada causar? (LAURENTIZ, 2006).

Um dos desafios mais importantes do trabalho nas redes telemáticas consiste em levar um número abrangente de indivíduos a constatar sua qualidade de seres que habitam um universo que os ultrapassa. Pertencer à rede, no interior das NTC, ratifica nossa minúscula posição de sermos partes constitutivas de um todo, e somos assim liberados para que sejamos "cidadãos do universo". Segundo Pierre Lévy "Nós vivemos um desses raros momentos onde a partir de uma nova configuração técnica, quer dizer de uma nova relação com o Cosmos, se inventa um estilo de humanidade" (LÉVY apud PRADO, 1997). Mas é importante ressaltar que nesse trabalho coletivo "ninguém fica de fora, nem mesmo quem é excluído do processo por não querer ou não poder participar", segundo o teórico Laymert Garça dos Santos (GARCIA DOS SANTOS, 2003:10). No trabalho em rede somos 'um' mas ao mesmo tempo somos 'um' conformado pelas diferenças que precisam umas das outras. A relação orgânica que nos constitui como ente humano é um conceito já indiscutível, que vem se radicalizando desde os anos vinte (CHARDIN apud COSTA, 1995) com a sucessão de tecnologias que nos ligam e 
intercomunicam como comunidade 'humana'. Só cabe tomar cuidado com a importância de ressaltar que as mudanças nos acontecem, mesmo sem termos concordado.

O mundo alternativo da realidade virtual está se instalando no mundo, e se infiltrando entre nós e o mundo. Mas em vez de ele aterrissar em nosso espaço, como imagens de televisão, muito ao contrário, parece que somos nós que mudamos de dimensão e, ao mudarmos, mutamos.

Por enquanto são só uns poucos privilegiados, como os usuários da Internet que se encontram para partir em "viagem" virtual a bordo de seus visores; mas quando milhões de consumidores do mundo inteiro tiverem acesso a essa tecnologia, a mutação deixará de se constituir como exceção, para tornar-se norma. E a realidade virtual vai tornar-se uma realidade para muita gente (GARCIA DOS SANTOS, 2003:113).

Assim, o trabalho em rede hoje é uma efetivação das ideias sugeridas pelo texto escrito. O conceito de rede existia já antes da Internet no texto escrito (BARTHES, 1970, DERRIDA, (apud LANDOW, 1992) e FOUCAULT, 1969), mas é no computador que se dão as soluções práticas a essas noções, aportando também características novas à criação colaborativa que não tinham sido pensadas pelo texto. Da mesma maneira, na criação em rede é a tecnologia como a Internet a que junta pessoas e saberes para a criação conjunta (ASCOTT, 2003, LÉVY, 1993, LANDOW, 1992, LAURENTIZ, 2004 e 2006, PRADO, 1997 e GIANNETTI, 2006). Mas parece que tal diversidade só acontece como uma ilusão na rede virtual da Internet e, assim, a Internet carece da pluralidade de pontos de vista realmente diferentes que se espera que acolha. A "multivocalidade" (LEÃO, 2001) que se espera que a Internet contenha ainda pode ser amplamente explorada.

A criação coletiva na Internet só está considerando a junção das partes que têm acesso às ferramentas tecnológicas comunicativas o que produz um primeiro movimento de desconsideração do diferente. Ressaltemos que no Brasil só $33 \%$ da população tem acesso à Internet (IBOPE e IBGE, 2009) e se os favorecidos apontam à web como a definição do que é 'ser humano' hoje, faz sentido contar com uma comunidade virtual que seja realmente representativa e heterogênea, isto é, que inclusive encontre freios no seu desenvolvimento pela complexidade das diferenças daqueles que constituem o universo virtual.

Em segundo lugar, ao contrário de posições como as de Roy Ascott (2003) e Lévy (1993), o trabalho numa rede que aglutine verdadeiramente as diferenças mostraria dificuldades na sua elaboração. A partir desta premissa, parece que o trabalho em rede da "Consciência Global" não está realmente aberto ao acesso da 
maioria da humanidade e, pelo contrário, depara-nos com a ilusão da junção dos opostos que deviam compor a "Inteligência Coletiva".

Devemos cuidar então para que a definição do que é ser humano hoje, nascida a partir do trabalho em rede, considere a complexidade do trabalho coletivo. Para definir a nova humanidade que nasce da criação em rede devemos politizar a discussão sobre os coletivos virtuais para considerar dentro do "novo ser humano" de que trata Lévy, até os que não acompanham necessariamente esta evolução (TRIVINHO, 2007, MACHADO, 2007, GARCIA DOS SANTOS, 2003).

O debate sobre a criação em rede hoje deve conter de igual maneira, como menciona Edward Said (1999:93), uma consciência incômoda e aguda ante o inevitável contexto imperial, presente em tudo. Isto com o objetivo de manter uma comunidade acima da coerção, a crítica acima da mera solidariedade, a vigilância acima da concordância (SAID, 1999:90-91).

Nos termos de Laymert Garcia dos Santos (2003), aquela primeira época da aparição da Internet que falava da promessa de que o desenvolvimento tecnológico permitiria a inclusão de todos e todas, não existe mais, e só é mantida pela publicidade. Da ideia da troca entre "ou eu ou você" pelo "eu e você" (FULLER apud GARCIA DOS SANTOS, 2003:126) só fica a primeira categoria ainda mais radicalizada nas distâncias entre as classes e os países, intensificando a luta pela sobrevivência e pela competência tecnológica. A nova linha de evolução se fortalece com a nova "classe virtual" erigida em torno do consumo dentro do capitalismo que arranjou novas maneiras de imposição.

É frente a essa comunidade virtual ainda muito homogeneizada - leia-se desequilibrada - que se faz imprescindível convidar à diferença se quisermos falar de uma verdadeira "consciência global" (ASCOTT) ou de "inteligência coletiva" (LÉVY) que produz conhecimento e arte. 


\subsection{Algumas problemáticas da arte da web}

Analisaremos aqui o trabalho da arte, em especial o da net.arte ${ }^{4}$ para, a partir disso, aproximar a produção do artista das NTC a consideração de seu contexto tecnológico de maneira crítica, tirando assim este artista da esfera global da web e trazendo-o de volta para seu ambiente local.

Da mesma maneira que no início da época moderna de Hegel, hoje também temos a impressão de que as dificuldades da vida se agravaram. Parece-nos igualmente que esse agravamento resulta da "maior complexidade de nossa vida social e política" e interroga-se sobre a "função da arte e do seu lugar no conjunto de nossa vida" (JIMENEZ, 1999:186).

A partir do uso das NTC as mudanças na percepção estética estão sendo potencializadas pela arte como nunca antes. A arte contemporânea na web radicaliza o aspecto de compartilhamento e diálogo da experiência estética ao abarcar de maneira eficiente um maior grupo de participantes. O desafio da estética contemporânea, de acordo com o teórico Marc Jimenez, procura pelo 'como se faz' arte hoje, adaptando-se às novas condições, e para tanto examina como os artistas convidam a viver intensamente uma experiência de ruptura com o cotidiano (JIMENEZ, 1999:390).

Diante de propostas que podem intrigar, chocar, desorientar, irritar, as vezes também entusiasmar e deslumbrar, a tarefa da estética consiste em prestar atenção nas obras a fim de perceber as relações que elas estabelecem com o mundo, com a história, com a atividade de uma época. A experiência estética contemporânea oferecida pela net.arte ajuda, ainda mais do que nas manifestações artísticas anteriores, na exigência de Kant de ser uma vivência para sair da solidão, da experiência individual e subjetiva, levando a abrir essa experiência estética se não a todos, pelo menos ao maior número possível (JIMENEZ, 1999:390).

É nesse contexto que a arte continua propondo uma experiência estética que age de acordo com os grandes princípios sem finalidade particular, o que redunda em benefício da liberdade humana (KANT apud JIMENEZ, 1999). A arte feita no interior das dinâmicas de comunicação como a Internet devia sugerir ao ser humano novas liberdades em relação às experiências subjetivas vivenciadas, acessíveis e válidas universalmente (JIMENEZ, 1999:139).

Por outro lado, as noções das quais falava Kant da arte como "satisfação desinteressada" e "finalidade sem fim" parecem hoje fazer parte de utopias ingênuas

\footnotetext{
${ }^{4}$ Arte feita em rede. Arte ao interior da Internet.
} 
(JIMENEZ, 1999:142). De acordo com Marc Jimenez (1999) a atitude contemporânea diante da arte parece diametralmente oposta às exigências e esperanças de Kant na procura de um sentido transcendental para o ser humano. A arte, tanto em sua realização quanto em sua recepção, responde hoje a interesses múltiplos de distração, busca hedonista, autocelebração, promoção de uma política cultural e, naturalmente, proveito e rentabilidade. Nossa relação atual com a obra de arte não passa de um exercício racional na procura pelo seu lugar (JIMENEZ, 1999:180) e tal parece que se comprova também hoje que a arte está ultrapassada como o estava já na época de Hegel (HEGEL apud JIMENEZ, 1999:180).

A respeito disso já comprovava Mario Costa (1995:45) que: "o pensamento filosófico de Jochmann a Hegel, de Nietszche a Ortega, de Adorno a Gadamer, de Geiger a Sedlmayr, denunciou a progressiva perda de sentido e a banalização da arte". Ela deixou de desempenhar um papel vital e se dissolveu no consumo, na decoração e no entretenimento. Mas o autor propõe da mesma maneira uma saída para a estética e para os artistas contemporâneos podendo estes encarar o novo contexto como um âmbito adequado para as propostas além do puro entretenimento. Eles podem traduzir as novas forças do contexto tecnológico em prol da educação sobre tempos vindouros em relação ao que significa ser humano (COSTA, 1995: 45). Eles devem, segundo Costa (1995:42), tomar partido impessoalmente e pôr em obra a ideia da potência humana e da superioridade da razão.

As novas tecnologias prometem e tornam possível uma verdadeira evolução do espírito: pôr em obra uma objetividade sublime que, sem pertencer a ninguém, auxilie como acréscimo na vida espiritual de todos. É a isso que os artistas são realmente chamados. (COSTA, 1995:57)

A obra de arte no contexto particular da Internet pode ainda ser capaz de pôr em crise a civilização burguesa, na medida em que subtrai ao homem médio das formas e sistemas herdados como a "boa forma" que Ihes impedem vivenciar sua própria liberdade, tal como propunha Umberto Eco para a arte de 1962. Assim, a obra de arte cumpriria com a função pedagógica de ruptura de modelos e esquemas que permitindo uma possibilidade de recuperação da autonomia (ECO, 1962:148).

Todavia, autores como Arlindo Machado (2007:54-56) chamam a atenção para o fato de que a arte pouco se posiciona criticamente em relação ao contexto social hoje, deixando de lado sua perspectiva mais radical. No contexto da criação com tecnologias como a Internet, a discussão estética foi quase inteiramente substituída pelo discurso 
técnico e em vez de procurar por ideias criativas pela subversão das normas e a reivindicação da vida, discutem-se algoritmos, hardwares e softwares. As novas tecnologias eletrônicas parecem mais falar de perícia profissional e das habilidades técnicas arriscadas, que substituem as atitudes mais radicais da arte em relação às interrogações mais profundas e dramáticas de nosso tempo. Faz-se necessário, então, segundo o autor, restabelecer o link entre a atividade criativa e o inconformismo na arte contemporânea, o qual foi cortado por teses sem sentido sobre o momento pósmoderno (MACHADO, 2007:54-56).

Para Machado, as questões sociais deviam estar mais refletidas na arte feita a partir desses contextos. A arte devia, segundo o autor, servir de problematizadora das novas formas de dominação baseadas em gênero, classe, raça ou nacionalidade, assim como crítica às guerras imperialistas, aos genocídios, ao terrorismo, à migração internacional e à intolerância com relação aos estrangeiros entre outros. Também servir à crítica da vigilância universal, à globalização predatória, à espetacularização da vida e à degradação ambiental (MACHADO, 2007:54-57). O teórico propõe que a arte inclua, igualmente, o debate sobre as novas formas de engajamento social direto baseadas nas redes telemáticas, nas mídias táticas, na utilização de sistemas de distribuição multiusuários para a criação de obras colaborativas realmente coletivas, na busca de novas políticas do corpo e a expressão de identidades culturais diferenciadas (MACHADO, 2007:57).

Um novo sentido poderia surgir na arte contemporânea, procurando por aproximações próprias às novas tecnologias em contextos específicos como o nosso, o latino-americano. Essas obras podem convidar efetivamente, e cada vez mais ativamente, os participantes, podem nos juntar para vivenciar em coletivo, "salvandonos" da banalização da arte (COSTA, 1995). É por esse motivo que se faz necessária uma aproximação que considere o particular e local dos artistas das periferias, para que seu trabalho represente posições estéticas pertinentes à sociedade a qual pertencem e que, no global da arte da Internet, aparece silenciada.

Como anota Arlindo Machado:

O desafio da artemídia não está na mera apologia ingênua das atuais possibilidades de criação. A artemídia deve, pelo contrário, traçar uma diferença nítida entre o que é, de um lado a produção industrial de estímulos agradáveis para as mídias de massa, e de outro, a busca de uma ética e uma estética para a era eletrônica (MACHADO, 2007:17). 
Além do mais, o autor das propostas artísticas na rede que lida com coletivos em contextos periféricos deve ser crítico frente à técnica, já que considerar a máquina como autor faz parte do passado: "em um primeiro momento, impressionado e sem fôlego pela investida tecnológica, espanto suscitado pela radicalidade e pelo ineditismo das mudanças anunciadas" (GARCIA DOS SANTOS, 2003:12). O autor se submergiu na problemática da 'máquina' mesma, tal como acontece quando uma nova técnica é apropriada pela arte. O artista - ou ao menos muitos deles - falou então a partir da máquina, amalgamando-se com ela, virando máquina, tornando-se algoritmo e canal comunicante, o que trouxe um resultado precioso para um primeiro momento introdutório. Portanto, o artista do contexto tecnológico assumiu num primeiro momento, a responsabilidade de inserir a sociedade nas mudanças sensoriais que traziam as evoluções tecnológicas, prescrevendo para o coletivo fórmulas sensíveis de futuro e possibilidades estéticas abstratas que nos desvendaram isso tão novo que eram as NTC. Só que se passaram dezessete anos desde a aparição da Internet e se faz necessária uma aproximação crítica à arte e à sociedade desenvolvidas em torno e no interior da web. Uma tecnologia como a Internet que, mesmo sendo adolescente, já dirige maneiras de viver, pede que seja também encarada de maneira crítica. Pede-se assim do autor da net.arte que entre num segundo movimento, desta vez vindo de dentro do social:

O impulso de procurar entender e explorar os efeitos desestruturadores e/ou reestruturadores que a tecno-logia acarreta numa percepção política da realidade. Num espírito que recusa a admitir a supressão da política e acredita, muito ao contrário, que na situação contemporânea a política deveria considerar a tecnociência como seu objeto de crítica por excelência (GARCIA DOS SANTOS, 2003:12).

Tanto que os autores das NTC compartilhavam com a máquina comunicacional o status de autoria na premissa 'McLuhiana': "O meio é a mensagem" (MCLUHAN apud VALVERDE, 2007:91). Para a teórica Giselle Beiguelman (2008) cada leitor na Internet é um editor potencial e a validade da informação passa agora por instâncias como solidez da formação cultural, por fora da importância do nome próprio, "a logomarca de uma empresa ou o brasão de instituição". Como ressalta a teórica, o perigo é que no momento atual, o problema da autoria na rede equivaleria a do xerox (BEIGUELMAN, 2008) e o autor hoje deve olhar para as tecnologias como ferramentas a usar para se comunicar, e não mais como fim último de seu labor. Desta maneira 
afasta-se o perigo de tratar a autoria como se fosse um status compartilhado entre autor e máquina nas criações no interior das redes comunicativas virtuais.

Acreditamos que a arte possa demarcar, senão saídas e soluções, uma exposição crítica da sociedade. Na procura por alcançar um acréscimo na vida espiritual que seja igual para todos e todas, confiamos que os trabalhos de arte das redes telemáticas, mais ainda do artista que trabalha em contextos marginais das potências tecnoeconômicas, podem também considerar uma crítica da alienação aos produtos culturais. Frente ao paradoxo de estar alienados de algo que nós mesmos temos produzido, o artista pode gerar um estranhamento que nos separem, ainda que seja só um pouco, desta alienação (HEGEL e MARX apud ECO, 1962).

No contexto contemporâneo há uma glorificação dos produtos e dos benefícios do progresso tecnológico promovidos pelas estratégias de marketing, o que tenta se contrapor a uma crítica dos riscos na adoção da estratégia de aceleração tecnológica total. O trabalho com as novas tecnologias não têm sido discutido em toda sua complexidade: "as opções tecnológicas são sempre questões sociotécnicas, e devem ser encaradas pela sociedade como de interesse público" (GARCIA DOS SANTOS, 2003:11-12). É em relação a isso que a criação artística é também chamada a debater.

Faz-se necessária a discussão do deslocamento dos locais produtores de tecnologia, ainda mais se o acesso aos bens tecnológicos é ainda seletivo e discriminatório nos contextos periféricos. Acreditamos que essa aproximação às tecnologias, mesmo sendo diferente e marginal, amplificaria as experiências estéticas e as propostas artísticas independentes, problematizadoras e divergentes, que acontecem também em várias partes do mundo (MACHADO, 2007:31).

Também isso se espera da diversidade nas propostas dos artistas das NTC: que suas posturas sejam críticas em relação a seu contexto para problematizar a utilização das mídias técnicas contemporâneas nas obras de arte. Isso com o propósito de criar um debate mais rico em torno da generosidade expressiva oferecida pelas novas mídias. 


\subsection{Algumas referências críticas sobre a arte das NTC e as fronteiras}

Apresentaremos aqui algumas propostas artísticas que questionam os limites geopolíticos a partir da Internet, local virtual que tem sido oferecido como o lugar em que a diluição das fronteiras físicas acontece. É da virtualidade da mídia que se valem tais propostas para ir além dos limites legais a partir da arte.

Num mundo que acrescenta os controles das fronteiras, a Internet aparece como uma mídia que incorpora, não soluções reais, mas a ilusão de estarmos interconectados compartilhando uma experiência global do mundo. Afrontando o paradoxo entre margens virtuais e reais, alguns artistas têm desenvolvido propostas em que questionam o problema dos trânsitos do contexto político internacional contemporâneo. Nessas propostas a Internet é questionada sobre seus limites legais e políticos como mídia que transgride certo anonimato às normas vigentes. Tais propostas saem da metáfora da criação de uma nova realidade para examinar a maneira como habitamos a mesma realidade.

Que a arte seja sempre autobiográfica (MUNTADAS, 2007:122) é mais do que premissa para trabalhos como Passport de Andreja Kulunčić, Looking for a Husband with an EU Passport e Crossing de Tanja Ostojic. Nesses trabalhos o lugar de nascimento das artistas é um eixo sutil que permeia a experiência de mundo. As fronteiras e as relações internacionais são trazidas para a discussão, tanto que a intimidade ajuda a compor um espectro mais abrangente do assunto. Isso é mostrado no trabalho feito em 2000 por Tanja Ostojic.

Após tentar obter um visto europeu e desenvolver uma série de performances sobre o assunto, a artista deu um passo adiante e produziu Looking for a Husband with an EU Passport:

(<http://damp.nsk.hr/arhiva/vol1/1126/7327/artefact.mi2.hr/_a01/lang_en/art_ostojic_en. htm>). 


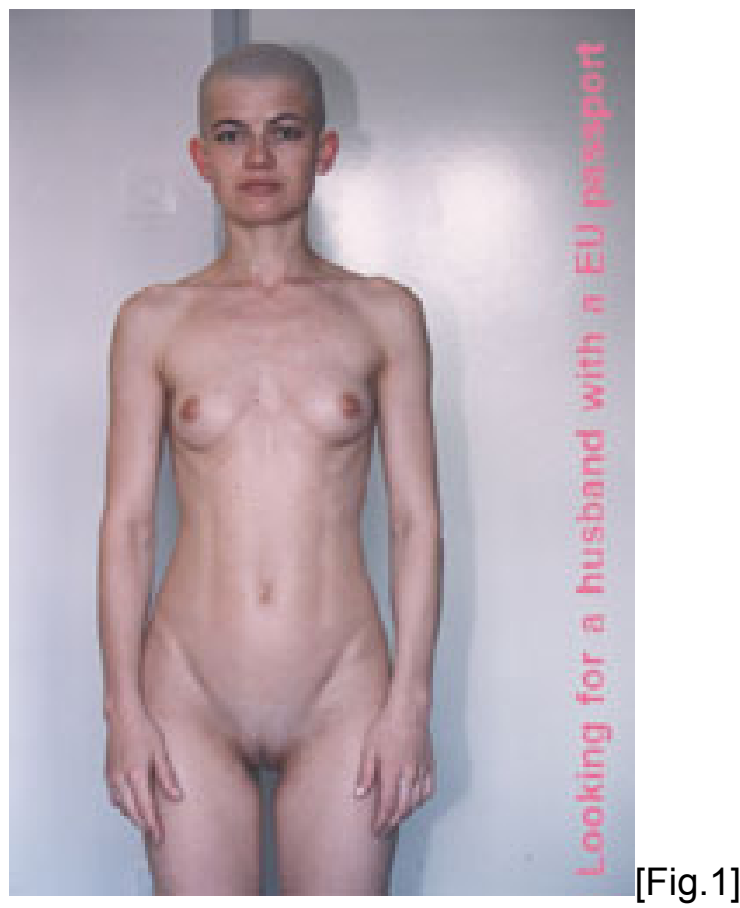

O trabalho traz necessidades reais para o cenário artístico, uma vez que a artista busca um visto europeu através de um casamento falso procurado publicamente pela Internet.

Sem dúvida a necessidade da artista trabalhando num país colapsado economicamente e destroçado pelas guerras foi definir sua própria posição, sua própria identidade e sua atitude frente à realidade social.

Em um segundo nível seu corpo nu em público foi deliberadamente apresentado sem caráter sedutor nem sensualidade, na pura fisicalidade de sua carne, toma a posição de um convite escrito, mas ao mesmo tempo de repulsa visual. Ele (seu corpo) estava então representando o papel da mensagem política ${ }^{5}$ (ZORAN, 2002).

Posteriormente teve lugar a performance Crossing (em 28 de novembro de 2001) em frente ao Museu de Arte Contemporânea de Belgrado.

\footnotetext{
${ }^{5}$ Neste caso o termo "política" refere-se às políticas do corpo feminino, divergindo do uso que temos feito do termo ao longo do texto, em que política corresponde à ciência de administração de nações ou Estados.
} 


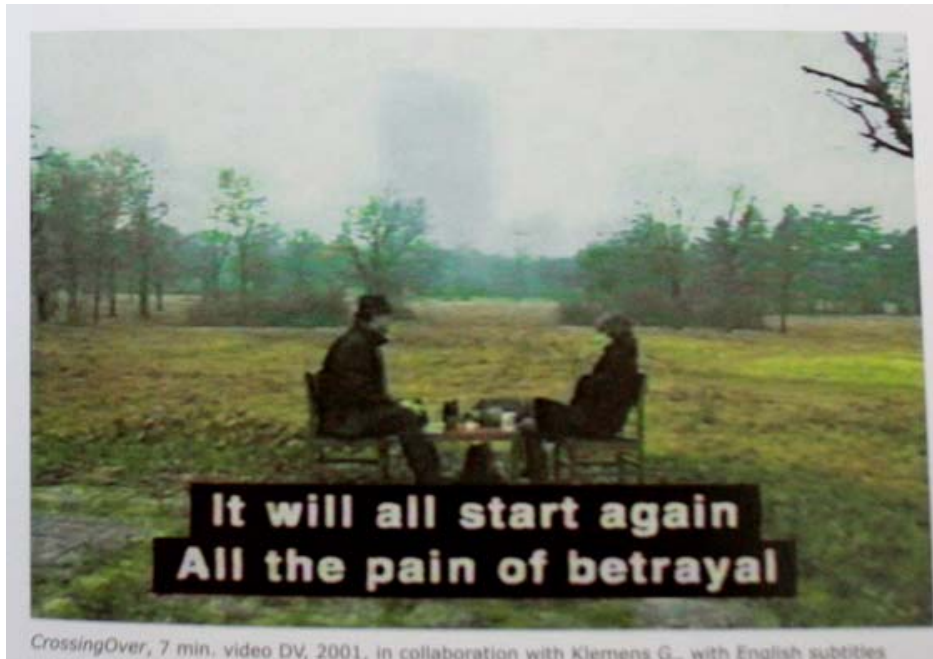

[Fig.2]

A peça consistiu no encontro com o artista Klemens Golf, que foi o escolhido entre muitos candidatos que responderam a um anúncio, publicado por ela, com quem a artista trocou correspondência por seis meses.

Esse primeiro encontro foi transmitido pela Internet e conduziu a um casamento secreto e privado em Belgrado, em nove de janeiro de 2002.

Sobre a série, a artista argumenta que fez os trabalhos "incorporando, com um pouco de ironia e humor (negro), a situação de lidar com o mundo quando se é uma portadora de um passaporte iugoslavo. Basicamente estes trabalhos mostram aproximações possíveis que refletem sobre tais situações humilhantes da vida cotidiana" (OSTOJIC, 2009). 
Outra proposta a respeito das permissões para atravessar as fronteiras é dada por Andreja Kulunčić no trabalho interativo e online Passport (<http://embryo.inet.hr/passport>), Abril 2001.

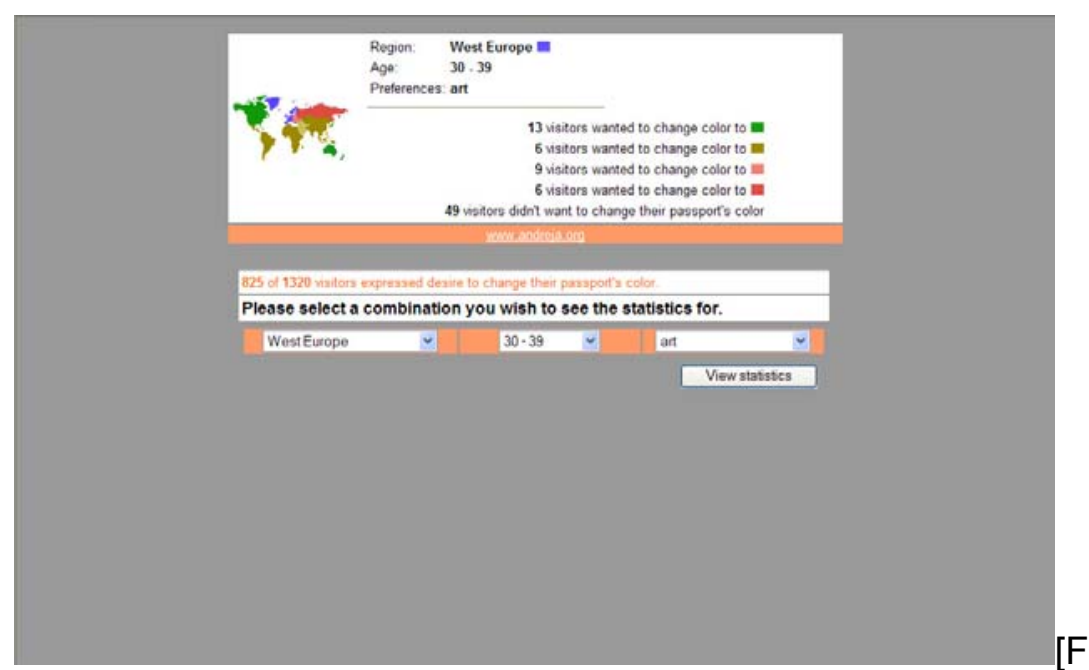

[Fig.3]

O trabalho consiste em selecionar a cor do passaporte de um filho(a) imaginário(a). O trabalho é uma espécie de questionário, arquivo estatístico e um tipo de jogo social. No mapa socioeconômico do mundo, pode-se clicar na cor da região de onde gostaria que seu filho(a) virtual fosse originário(a), como uma projeção dos próprios desejos (KALCIC).

O passaporte é o fetiche do mundo criado no século $X X$, trazendo segregação das pessoas nas fronteiras. Tal segregação é baseada na cor dos passaportes que se carregam, argumenta Jergovic (apud KALCIC).

Por outro lado, a respeito da mobilidade, cabe anotar que "só $4 \%$ da população viaja por ar, tanto que para muitos seus movimentos estão restritos de acordo com razões econômicas ou político-legais" (KALCIC).

A terceira obra é dos artistas ingleses Heath Bunting e Kayle Brandon que apresentam outra perspectiva em BorderXing (<http://www.irational.org/borderxing>), um guia para cruzar as fronteiras tanto para ativistas como para pessoas que não possuem documentos necessários na Europa. 

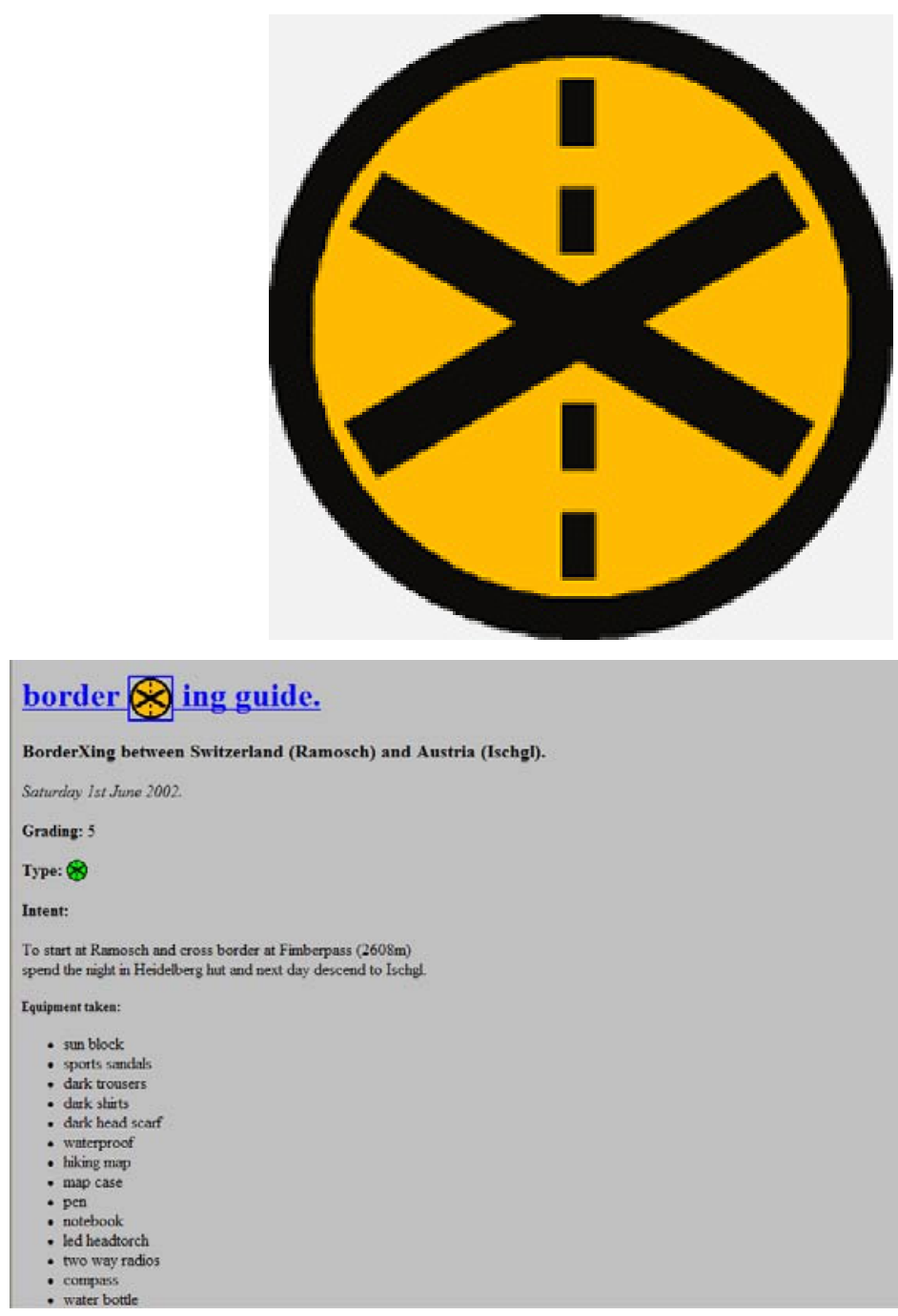

[Fig.4]

Os(as) interessados(as) em obter a informação devem ser usuários autorizados, o que evidencia o controle que o trabalho tem do uso dado da informação.

BorderXing subverte a integridade das fronteiras nacionais, assim como da nossa expectativa em relação a Internet como um espaço de acesso aberto a todos(as).

Sobre a problemática da criação para a Internet que pretende ser global, isto é, sem lugar, cabe lembrar que o lugar dá significado ao pertencimento (TUAN apud MOREIRA, 2007:6). Faz-se imprescindível, então, chamar a atenção para que se localizem os participantes do cenário global que se pretende incluir numa participação equitativa na rede virtual da Internet, segundo o teórico Ruy Moreira (MOREIRA, 2007:8). E isso deve ser também considerado para a criação artística. Contrário às ideias de perda do lugar que se pretende sofrer na Internet, torna-se relevante insistir na autoria que provém de um local em contraposição do global. Como uma nova maneira de ser autor no espaço das novas tecnologias comunicacionais, o autor do qual falamos 
representa mais equilibradamente uma comunidade, assim como é o crítico em relação ao seu contexto. É a execução dessa premissa sobre a autoria o que temos perseguido durante a pesquisa e os projetos práticos do mestrado. 


\section{Capítulo II: Algumas questões da imagem fotográfica digital}

A ferramenta que tem acompanhado o work in progress desenvolvido durante o período do mestrado é a fotografia. Detemos-nos nela para analisar as mudanças que tem sofrido com sua digitalização e seu posterior uso nas criações coletivas na rede Internet.

\subsection{Algumas questões da imagem fotográfica}

Com a aparição da fotografia digital a imagem fotográfica muda. Essa nova linguagem fez possível usar a fotografia nas criações coletivas.

Com o digital, isto é, o numérico, o ato fotográfico se vê transformado permitindo-nos compreender a evolução da arte fotográfica. A fotografia não é mais uma imagem da realidade, mas uma imagem da imagem. Isso faz com que, no ato fotográfico, o sujeito não se instale mais diante do real, mas num primeiro momento diante da imagem e em um segundo momento dentro da imagem. $\mathrm{O}$ que se olha no ato fotográfico contemporâneo é a máquina e a imagem simultaneamente. O homem que enfrenta a fotografia digital não tem mais o olho colocado no aparelho, assim, pode ter outra relação com a máquina e consequentemente com o próprio corpo (SOULAGES, 2008:86).

Como Couchot assevera (1993:42), na imagem numérica se alguma coisa preexiste ao pixel e à imagem é o programa, isto é, linguagem e números, e não mais o real. Isso faz com que a fotografia numérica não tenha mais relação com o real, ou sua relação com este fica cada vez mais distante, já que esta imagem não representa, mas simula o mundo real. O constrói, fragmento por fragmento, propondo dele uma visualização numérica sem nenhuma relação direta com um real, nem físico nem energético. A "imagem-matriz digital" não apresenta mais nenhuma aderência ao real: libera-se dele. Faz entrar a lógica da figuração na era da Simulação (COUCHOT, 1993:42).

Mario Costa (1995) nota como a partir de Benjamin assistimos à "emergência de um pensamento estético voltado para a reproduzibilidade eletrônica das formas", as quais, a partir da aparição das novas tecnologias têm feito que a imagem contemporânea seja sintética e auto-suficiente. Nesta nova imagem o sujeito começa a tornar-se não encontrável e a eclipsar-se (COSTA, 1995:63). Sendo a imagem sintética, na sua essência, estranha a toda forma de subjetividade, aparecendo como um real em si e por si, emanado de um labor puramente intelectual que é o numérico na construção 
dos algoritmos. Tal processo não tem mais nenhuma relação com o sujeito (COSTA, 1995:64).

Por outro lado, Soulages (2008:83-84) acrescenta à postura de Costa sobre a independência da imagem fotográfica do real fazendo referencia à ruptura com o real. Esta acontece em um grau infinitamente maior com a imagem numérica, que pode tornar-se totalmente autônoma em relação ao real que the deu origem, passando da esfera que em algum lugar tratava de uma lógica fotográfica para uma lógica puramente numérica. Aqui incluímos também as imagens calculadas realizadas sem nenhuma relação com um real já existente (SOULAGES, 2008:83-84).

Desanti, por sua vez, evidencia o fato de que com a imagem numérica passamos do mundo das experiências para o mundo das idealidades, ou seja, o mundo da matemática. Deixamos o mundo da experiência para ir ao mundo metamorfoseado pela Renascença no que se reza: "ninguém entra aqui se não for geômetra" (apud SOULAGES, 2008:85).

A aparição da matriz numérica como substituta do suporte material fotográfico faz com que a estética numérica seja uma estética da hibridação com potencialidades infinitas. Ela se abre para uma cultura da hibridação, sob uma ordem visual infinitamente rica, sobretudo para uma nova maneira de produzir, de comunicar e de receber imagens (SOULAGES, 2008:83). Nesse contexto contemporâneo, presenciamos a aparição de um novo tipo de imagem fotográfica, produto da fusão de várias linguagens, revelando-se como uma "Entre-imagem", termo proposto por Raymond Bellour.

As novas imagens são passagens das representações intersemióticas entre fotos, cinema e vídeo produzindo uma multiplicidade de sobreposições, de configurações pouco previsíveis entre a produção destas imagens. Entre-imagens é o espaço de todas essas passagens e refere-se à dissolução das fronteiras entre os suportes e as linguagens. As imagens são compostas agora a partir de fontes mais diversas: parte é fotografia ou cinema, parte é desenho, parte é vídeo, parte é texto produzido em geradores de caracteres e parte é modelo gerado por computador (BELLOUR, 1997:14).

Aquelas imagens que são tudo ao mesmo tempo, que estão "entre" todas as linguagens, são chamadas de "mestiças" por Arlindo Machado (2007:69). Para o autor o interessante são as passagens entre analógico e digital, figurativo e abstrato, atual e virtual. $E$ isso porque as fronteiras formais e materiais entre suportes e linguagens não são tão rígidas hoje. $\mathrm{Na}$ atualidade vemos a mudança de um meio a outro, de uma 
natureza a outra - seja ela pictórica, fotoquímica, eletrônica ou digital -. É o trânsito entre essas naturezas a característica mais importante do contexto contemporâneo (MACHADO, 2007).

Dentro do contexto brasileiro, Rubens Fernández Jr. (apud MACHADO, 2007:67) se refere a essas novas imagens como "expandidas". São imagens em que a fotografia se hibridiza importando técnicas e ferramentas das artes plásticas e outras artes, migrando atualmente para o digital. Essa nova fotografia de limites expandidos aparece no momento em que a indexicalidade das imagens é questionada e relativizada.

Por sua vez, Ascott (2003:249) também prevê uma fotografia hipermidíatica na combinação da complexidade na captura, construção, arquivo e acesso aos dados, em vários níveis de resolução e em uma variedade maior de modos sensoriais e semânticos como são a imagem, o texto e o som. Assim, a fotografia digital entra numa espécie de espaço virtual, no caminho da hipermídia.

É o computador aquele que potenciou a aparição desse novo tipo de imagem. Arlindo Machado ressalta que os chamados "novos meios" só puderam se impor como "novos" e ser rapidamente aceitos e incorporados socialmente pelo que tinham também de "velhos" e familiares. O computador surge como uma mídia única que inclui todas as demais sendo, ao mesmo tempo, um híbrido no que cada um dos meios pode ser tratado separadamente (MACHADO, 2007:73).

Para apontar um caminho justo na criação em rede de imagens fotográficas, Prado sugere:

A imagem partilhada é «réplica» perfeita, tão real quanto a «original», presente, portadora de tempo, carregada de saberes inacessíveis, nas quais a sensibilidade individual é acrescida pela troca (...) É, portanto, na troca de dados que conformam a imagem contemporânea que se destaca a importância de que cuidemos que essas novas possibilidades nos autorizem a partilhar e não a impor uma visão/imagem do mundo. Que o "desvio" artístico ajude a trazer a liberdade da diferença e da escolha através do despertar/evidenciar aquilo que temos em comum e o que temos de diferente (PRADO, 1997).

A ideia de uma nova imagem fotográfica, em crise ou híbrida, possibilitou a concepção de propostas artísticas no contexto das redes virtuais.

$O$ respeito que se tecia em torno à fotografia analógica teria impedido que a imagem fotográfica nos acompanhasse no novo caminho pelo qual avançamos em rede. 
Permitimos à fotografia perder aos poucos sua aura: a manipulamos nos ambientes virtuais e coletivos e nos negamos o prazer da autoria individual, de sermos criadores únicos e singulares, permitindo aos outros compartilhar suas imagens. $O$ ambiente virtual que se cria colaborativamente com base na fotografia é um ambiente em que a fotografia fechada e intocável, isto é inacessível e sagrada, não interesse mais.

É nessa nova dinâmica social da criação coletiva em que o autor se escreve em plural e a fotografia enuncia novas perguntas. É diante dessas perguntas que surgem respostas mais polifônicas do que a que pronunciava a fotografia analógica. 


\subsection{Aproximação aos usos sociais da fotografia digital}

Com a digitalização da fotografia se amplia seu uso social e se cria também um novo tipo de socialização.

Tanto tem se difundido a prática da fotografia numérica no social que seu papel é fundamental para compreender a sociedade contemporânea. No âmbito atual, o texto não é mais o portador do sentido, já que tem relegado esta função à imagem fotográfica, a qual tem surgido como a portadora simbólica hegemônica. Vilém Flusser em Filosofia da caixa Preta, 1983, (apud MACHADO, 2007:43) verifica o funcionamento de nossas sociedades "pós-históricas" em torno da fotografia e segundo Machado (2007:43), entre as mídias de nosso tempo, a fotografia ocupa um lugar estratégico porque com base na sua definição semiótica e tecnológica se constroem hoje as máquinas contemporâneas de produção simbólica audiovisual.

Com a fotografia se inicia um novo paradigma na cultura do homem, baseado na automatização da produção, distribuição e consumo da informação, com consequências enormes para os processos de percepção individual e para a organização social. Mas foi com as "imagens eletrônicas (difundidas pela televisão)" e com as "imagens digitais (difundidas agora no chamado ciberespaço)" que essas mudanças se tornaram mais perceptíveis e suficientemente marcantes para demandar respostas por parte dos teóricos (MACHADO, 2007:43).

O fotográfico como ato social passa com a digitalização pela circulação e finalmente recepção das imagens produzidas a partir destes algoritmos, engendrando uma diferença material que cria novas relações com as imagens e uma nova sociabilidade da imagem.

A técnica digital faz que mudemos não apenas de paradigma mas também de relação com a imagem, bem como de relação com o mundo (SOULAGES, 2008: 80), mais ainda se levamos em consideração que são as imagens que reproduzimos as que configuram nosso mundo.

A nova prática fotográfica cobra seu preço em função do tempo, sendo a nova fotografia digital Cronófaga, devoradora do tempo (SOULAGES, 2008:90). Esse tempo é cobrado como a neurose de documentação do cotidiano, de seleção e ajuste de imagens e envio em rede das mesmas. A prática fotográfica cobra seu tempo e devemos aceder ou corremos o risco de ficar invisíveis e desaparecer do social.

Ao mesmo tempo a dimensão sagrada da fotografia desaparece já que o homem poderá sempre refazer uma foto que nada lhe custará, já que pode repetir dez, cem, mil 
vezes em poucos minutos e sem problema algum, nem técnico nem financeiro. Como se nesse novo sistema social a fotografia fosse leve, e nada fosse sagrado (SOULAGES, 2008:91).

No sentido mais amplo do contexto contemporâneo da criação em rede, Roy Ascott (2003) descreve as mudanças radicais que sofre a imagem fotográfica graças à abertura na sua produção e distribuição. Dessa maneira, uma nova prática fotográfica redunda em noções como a autoria, o que trará "efeitos sem precedentes na legitimação percebida da fotografia, sua autenticidade e o status cultural do artista fotográfico" (ASCOTT, 2003:249).

A nova prática social fotográfica se consolida como tal graças ao uso da rede comunicacional das novas tecnologias, em atividades que não necessariamente se inscrevem no artístico, e que não necessariamente trazem liberdade e crescimento concretos ao ser humano. A fotografia não é tanto uma prática que se faz, mas uma prática que se comunica e que, assim, cria rizomaticamente tribos, comunidades, grupos interconectados entre si (SOULAGES, 2008:91).

É assim como uma procura pelo sentido da fotografia na ampla utilização que dela faz o social pode marcar novos perigos até mesmo da criação em rede, tais como aponta Soulages, (2008:91-97) se corre o risco da gregarização de grupos fechados nos que não se dá espaço ao diferente. Assim como podemos intuir como o sujeito autônomo torna-se figura do passado, ficando relegado a um sujeito com menos autonomia porque está em rede, porque essa imagem irá articular-se com outras práticas.

Esse sujeito não-autônomo vive assim dentro da virtualidade do ciberespaço e através da socialização que faz da fotografia as diversas ilusões: a produzida pela rede, a da comunicação, ilusão de imediaticidade, assim como do tempo real, ilusão da ausência do espaço, e da ausência de tempo; enfim, ilusão da potência-total do corpo individual graças à sua inserção no corpo coletivo.

Com o numérico a fotografia não é apenas uma aventura íntima, privada e individual; ela é também uma prática exteriorizada, pública e política. É isso o que se joga nos usos da fotografia (contemporânea) não-artística e na fotografia de arte (contemporânea), em suas produções/criações, midializações/doações, comunicações/exposições e consumo/recepção (SOULAGES, 2008:97). 
É assim que a dimensão abrangente da nova socialização da imagem fotográfica facilita a participação em criações coletivas por parte de um amplo tipo de público.

Ela pertence já ao imaginário da sociedade contemporânea (FLUSSER apud MACHADO, 2007) e deste modo, sua linguagem é um lugar comum e também ponto de encontro. 


\subsection{Criação colaborativa da imagem fotográfica: alguns casos brasileiros}

Alguns trabalhos que têm servido como referência para a criação de propostas dentro do work in progress desenvolvido no mestrado e que utilizam a fotografia como base, são:

\subsubsection{Fernando Tacca, Big Brother (2001)}

<http://www.studium.iar.unicamp.br/bigbrother/index.html>
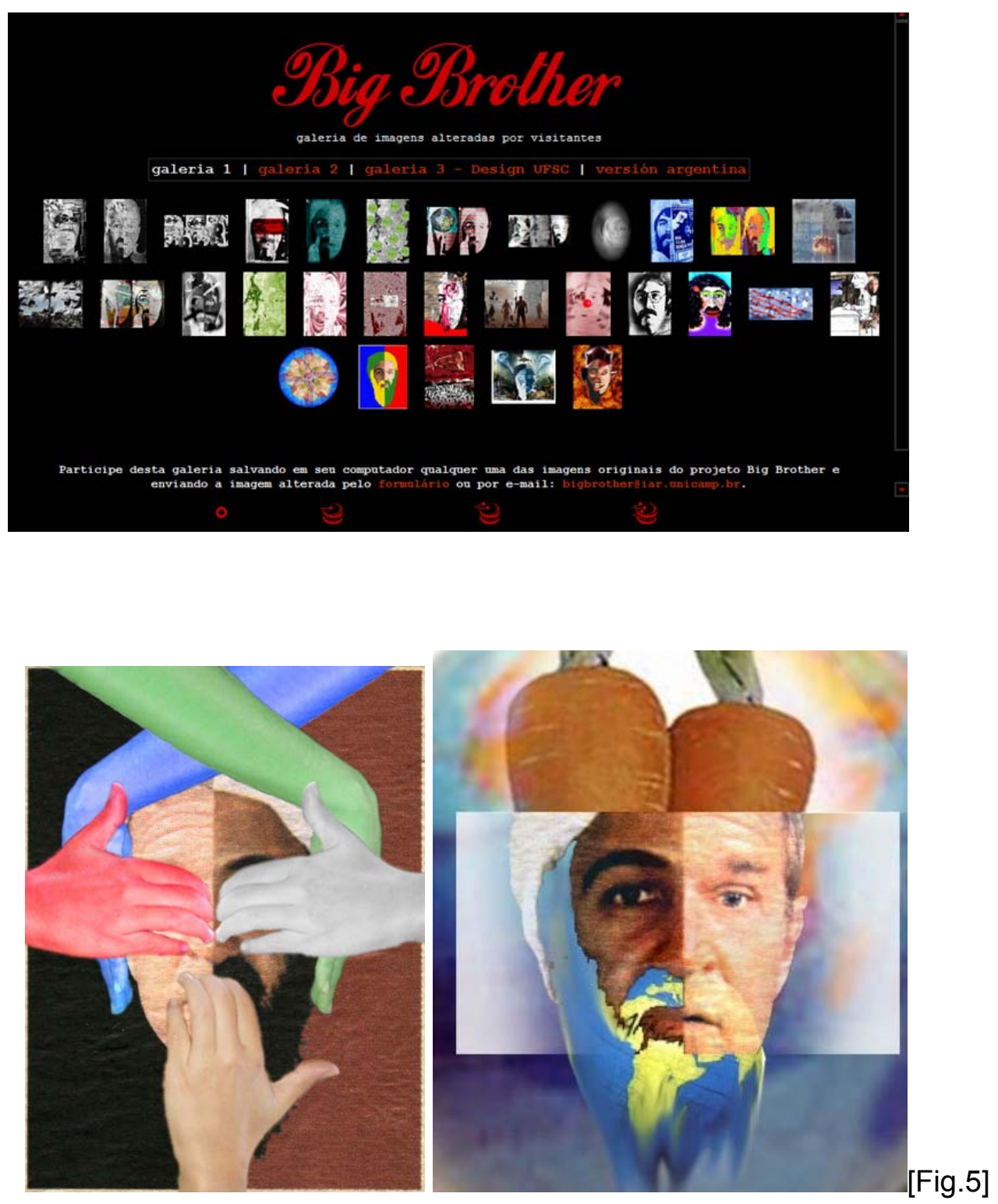
Dentro do perfil de obras brasileiras politizadas com ênfase na criação colaborativa de imagens fotográficas através da rede, vemos o caso Big Brother de Fernando Tacca (2001).

Após intervenções na cidade e uma instalação multimídia, em um terceiro momento do trabalho se desenvolveu a interface cibernética. Aqui é sugerido ao sujeito que capture uma das imagens em seu computador, interfira como queira e a retorne para uma galeria que será disponibilizada com essas interferências. Assim, o interator poderá também retrabalhar uma imagem já interferida e disponibilizada na galeria, criando uma comunicação similar à conhecida brincadeira do "telefone sem fio". No caso virtual, ao clicar no ícone do pequeno tambor disponibilizado na tela do computador, o sistema trará uma imagem aleatória para a tela. O mesmo irá acontecer quando o sujeito interferente clicar no tambor com duas baquetas ou no tambor com três baquetas, simulando o gesto presencial. O sujeito interferente poderá interagir capturando uma imagem, transformando-a com os recursos que tenha em seu computador e retornando-as para uma galeria (TACCA, 2001).

A ação individual valoriza o sujeito interferente colocando-o numa situação de dominação dos personagens e propondo, assim, uma reflexão a partir do ato lúdico interativo; uma busca de compressão através de seu próprio ato interferente no contexto contemporâneo bélico e terrorista personificado nos cartazes deteriorados, uma metáfora aberta para leitura do sujeito interferente (TACCA, 2001).

Cabe-nos perguntar se o imbricado da proposta, tanto nas várias etapas de apresentação como nas metáforas reproduzidas em relação às imagens, não obedece a aquilo que Arlindo Machado define como uma época neobarroca, ou segundo barroco. Talvez isso confirme o trânsito que vivemos na época atual, aceitando deliberadamente a pluridimensionalidade, a instabilidade e a mutabilidade como categorias produtivas no universo da cultura hoje (MACHADO, 2007:75).

Talvez tal 'barroquicie' do projeto de Tacca se refira ao que Severino Sarduy (apud MACHADO, 2007:75) em seu livro sobre o barroco afirma como um movimento sempre associado a momentos de crises, quando valores em que se baseavam os sistemas políticos, as crenças e as religiões são abalados por novas descobertas.

Em Big Brother o fator tempo parece sofrer um colapso. A velocidade imperiosa do mundo virtual quase nos força a considerar o ano 2001 como se pertencesse a préhistória. A obra perderia então vigência ao tratar, de um assunto já velho e 
ultrapassado? Ou pelo contrário resgataria a relação da fotografia com a memória, obrigando-nos a não esquecer o terrível ataque às torres gêmeas e, assim, o conflito?

Terá o Brasil necessariamente que assumir uma posição ante o ataque aos Estados Unidos para que isto esteja traduzido numa obra brasileira? Parece que as distâncias têm se encurtado e se faz pertinente tratar do assunto, ainda mais, como pretende Tacca, em se sentir com o poder para agir dentro dele.

Por outro lado a fotografia é aqui utilizada quase com cinismo: pegue-a, destruaa, use-a para mentir e finalmente faça a burla da guerra. Qualquer interator pode se aproximar do projeto com ânimo infantil e crítico. Ainda que deva saber usar as ferramentas de edição de imagens, o nível de autonomia do trabalho está aberto a qualquer tipo de colaboração, da mesma maneira que as novas tecnologias são usadas aqui como um suporte graças ao qual a crítica se socializa. 


\subsubsection{Nardo Germano, Doe seu Rosto (2001-2006) e Andromaquia (2004-2006)}

$<$ http://www.nardogermano.com/>

A proposta de Nardo Germano é reunida na tese de Mestrado apresentada para a Escola de Comunicação e Artes da Universidade de São Paulo, Auto-retrato Coletivo Poéticas de Abertura ao Espectador na Desconstrução de uma Identidade Coletiva (2007). Consiste na série Auto-Retrato Coletivo, organizada artisticamente como repositório crítico de uma "identidade coletiva", que é seu tema central. A série constituise de auto-retratos híbridos entre o Indivíduo e o Coletivo, questionando a construção identitária marcada por estigmas sociais.

Com o objetivo de, nesta fase, estabelecer novos contrapontos ao discurso mono lógico identitário oficial, bem como ao conceito de uma autoridade do artista como autor que controla os sentidos da obra, a criação partiu da hipótese de que o investimento nos graus de abertura à recepção podem promover o dialogismo e polifonia almejados, com a inclusão da alteridade, das expressões e dos pontos de vista dos espectadores na noção de identidade coletiva veiculada nas obras, considerando os conceitos de "obra aberta" de Umberto Eco bem como de "dialogismo e polifonia" de Mikhail Bakhtin (GERMANO, 2007:5).

Auto-Retrato Coletivo promove um movimento contínuo de construção e desconstrução identitária possibilitado pela abertura poética aos espectadores que, convertidos em participantes e/ou interatores, cumulativamente renovam, expandem e problematizam a identidade coletiva, inscrevendo-a na dimensão utópica de "Identidades Abertas".

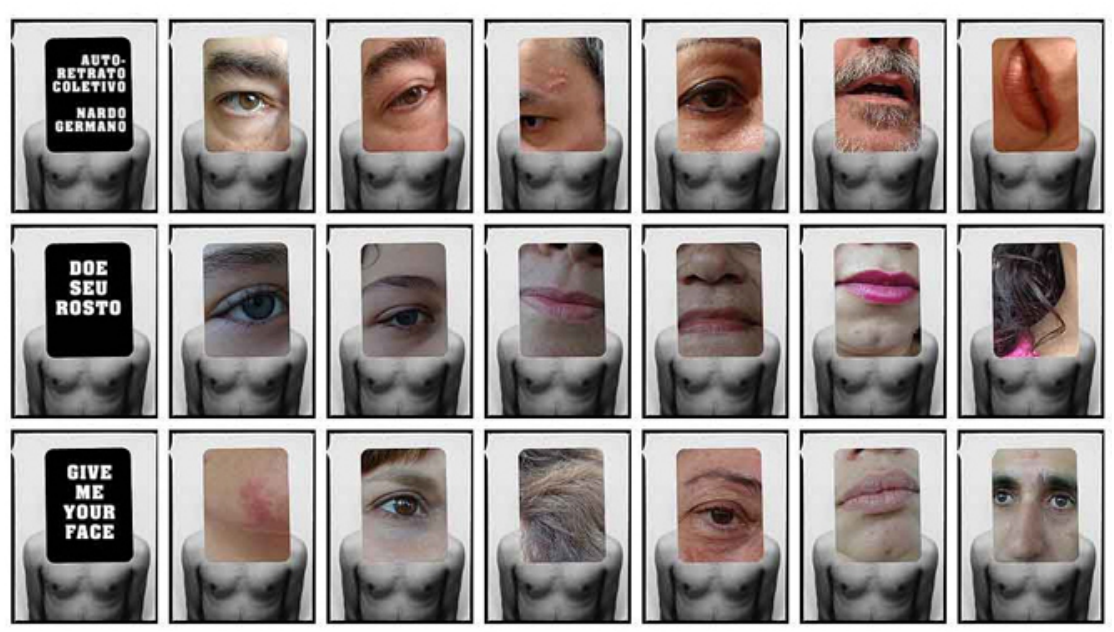

[Fig.6] 
Em Doe seu Rosto (2001-2006) os temas principais são participação e interatividade, convidando o público a doar a parte do rosto que prefere, num autoretrato mútuo com o artista, ao vivo, por webcam ou através de um e-mail fornecido por Germano (<autoretratocoletivo@nardogermano.com>). A pergunta aqui consiste em evidenciar o papel do artista como gerador de propostas que conseguem dar voz aos participantes. O retrato construído representa o coletivo invadindo a identidade do autor. Esse trabalho ressalta a pergunta fundamental no trabalho do artista sobre o eu e a identidade, discurso herdado dos anos 90 , que é atualizando nas dinâmicas da arte na Internet.
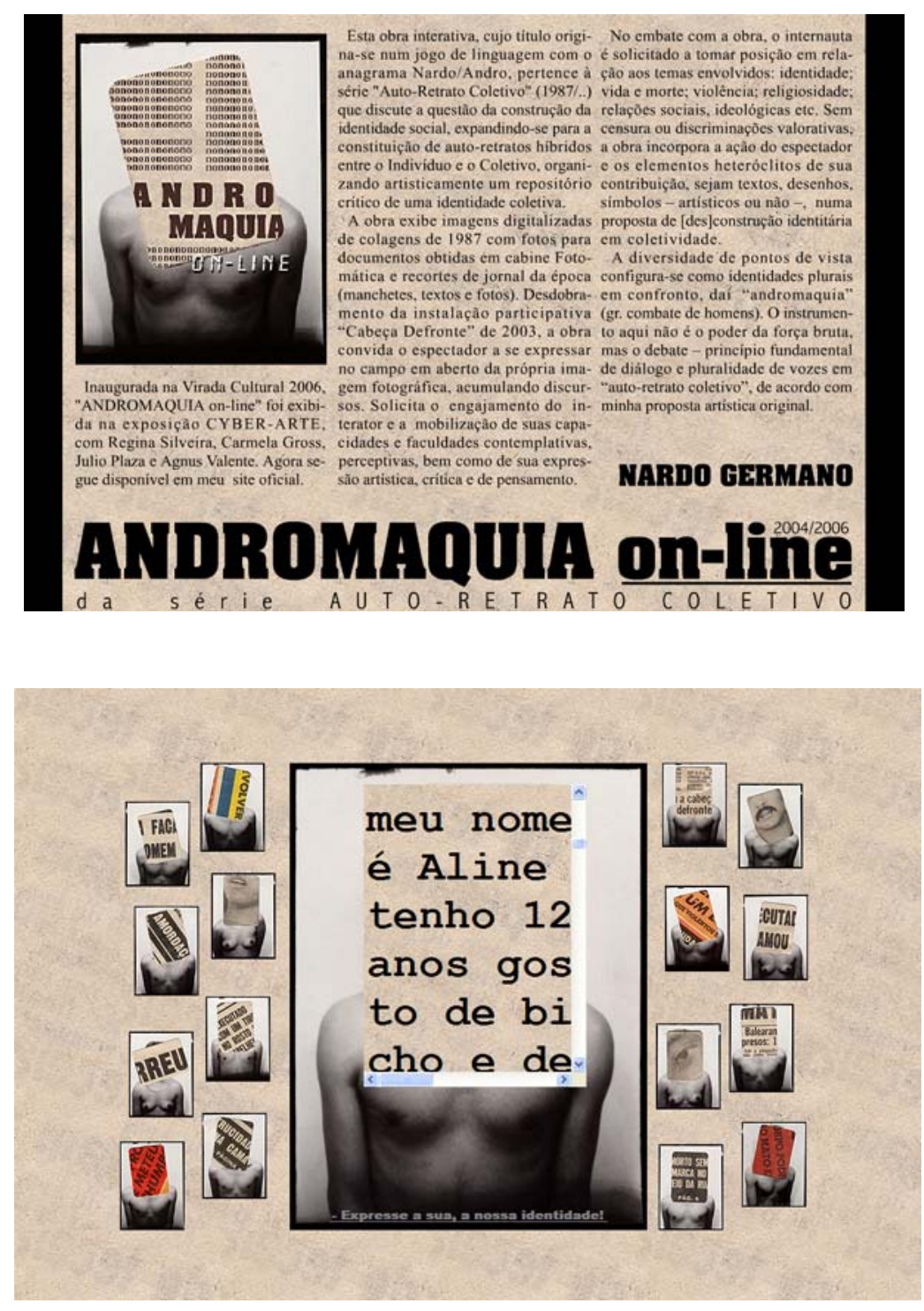

[Fig.7] 
Andromaquia, (2004-2006) é uma obra interativa online, propõe-se uma pluralidade de discursos sobre identidade coletiva enviados pelo interator a um banco de dados. Neste ponto Germano evidencia o caráter de imagem "mestiça" ou "entreimagem" da fotografia, fazendo com que, desta vez, seja o discurso escrito o que invada a imagem fotográfica criando um conjunto de sentido. Nas palavras do autor:

Num dado momento, submeto meu rosto: objeto fotográfico.

Outros seres, através de mim, encontram expressão.

Sua redundância multiplica-me.

E me transforma em todos: Identidade Coletiva.

Auto-Retrato Coletivo (GERMANO, 2006).

Nos dois trabalhos a fotografia exclama sua transmutação. Não é mais fotografia como documento ou memória, mas a imagem híbrida que permite a construção de novas metáforas, de novas maneiras de viver a identidade que se faz coletiva através da web.

Onde fica a ideia que tínhamos de identidade, agora que entramos nas dinâmicas sociais em que o ser se constrói em coletivo? Estamos nos perdendo na rede ou pelo contrário, esta nos nutre, fortalece e nos faz indivíduos potencializados? Sem ser nem apologético nem crítico, Germano mostra essas perguntas sem chegar a respostas conclusivas.

Ainda teríamos que ressaltar o fato de que se tratando da autoria dispersa oferecida pelos trabalhos colaborativos, o trabalho de Germano gira em torno de uma procura própria à qual os participantes se oferecem. É aqui onde o autor se nutre da rede e da participação online: construindo sua própria identidade e exibindo, a partir da arte, a complexidade deste conceito no momento contemporâneo. 


\subsubsection{Fernando Velásquez, O Colecionador de Espíritos (2003)}

$<$ www.blogart.com/colecionador>
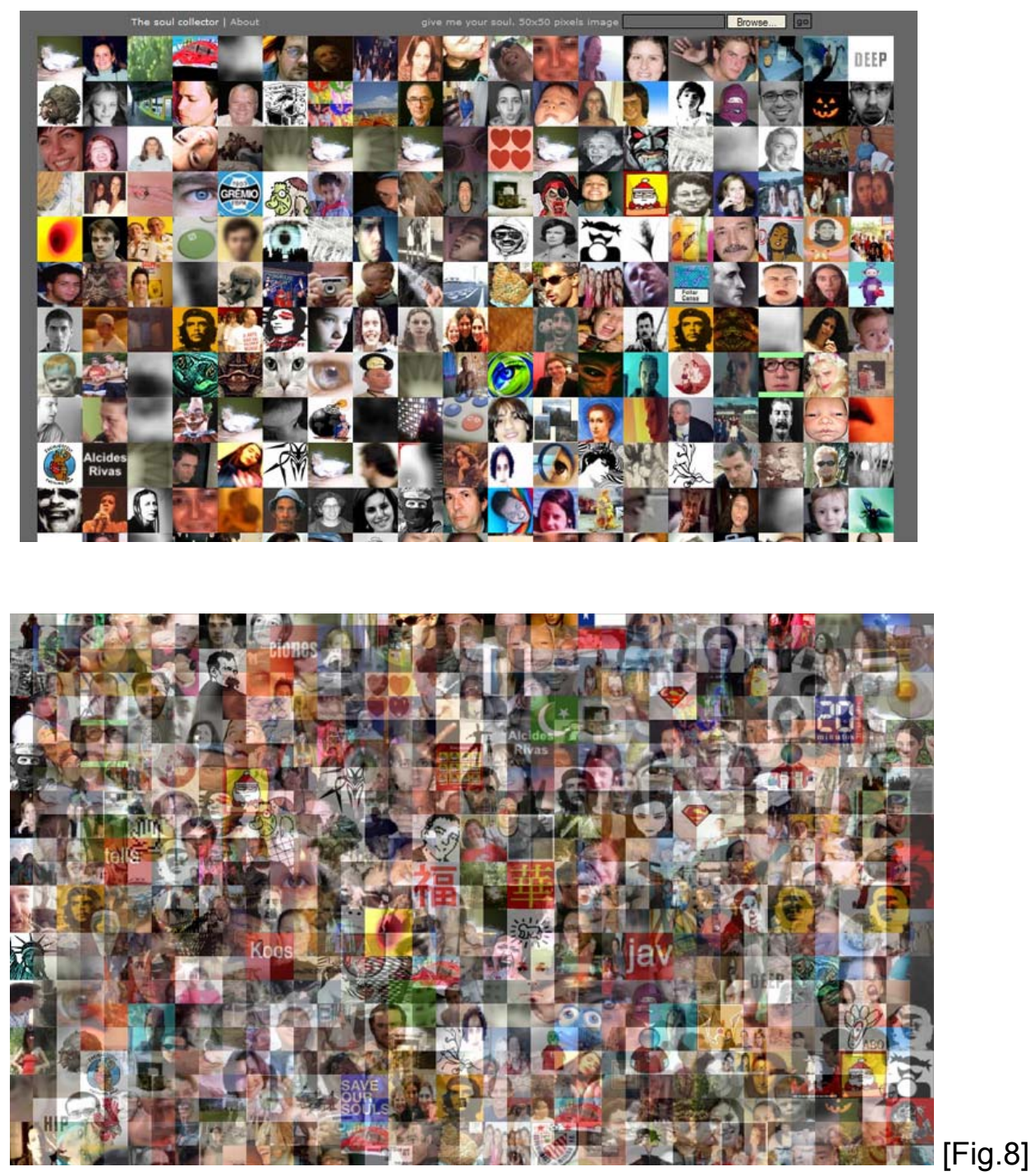

Em Colecionador de Espíritos, o artista persegue a utopia de colecionar as almas do mundo inteiro convidando os internautas a enviarem uma imagem de si próprios para uma base de dados on-line. Velásquez retoma a antiga lenda indígena que consistia em ver, no ato fotográfico, o roubo da alma do retratado por parte da máquina.

As imagens dos participantes se superpõem de maneira simples numa colagem final que faz alusão explícita ao termo de cibercollages de que fala Gilberto Prado. 
"Me dê sua alma" é a frase que aparece como convite à participação na tela do blog. Auto-denominado "soul collector" - colecionador de espíritos - Velásquez pede a alma representada numa imagem de 50x50 pixels. O resultado é uma camada um tanto transparente de fotografias, sobre outra mais definida, que lembra o passo do tempo e das vidas.

Aqui Velásquez faz alusão à função de memória e auto-representação da imagem fotográfica. Na proposta o artista fica invisível dando predominância às ações dos participantes, o que, junto com seu apelido de colecionador de espíritos, não faz outra coisa do que aumentar a sensação de ritual como proposta artística.

O Colecionador de Espíritos se apropria da fotografia que tem sido feita sem propósitos artísticos, isto é, das imagens que foram produzidas massivamente pela sociedade contemporânea. A partir do uso da collage fotográfica, Velásquez leva ao status artístico da fotografia digital feita sem pretensões nobres, quase exaltando a perda da aura, isto é, do sagrado da imagem fotográfica.

Assim como nos trabalhos de Germano, nessa proposta estamos todos desaparecendo na superposição das imagens que nos representam? É àquilo ao que as novas tecnologias estão nos condenando ou se trata, pelo contrário, de uma liberação de nós mesmos a partir da eliminação do individual? 
2.3.4. Kiko Goifman e Jurandir Muller, Cronofagia (2002)
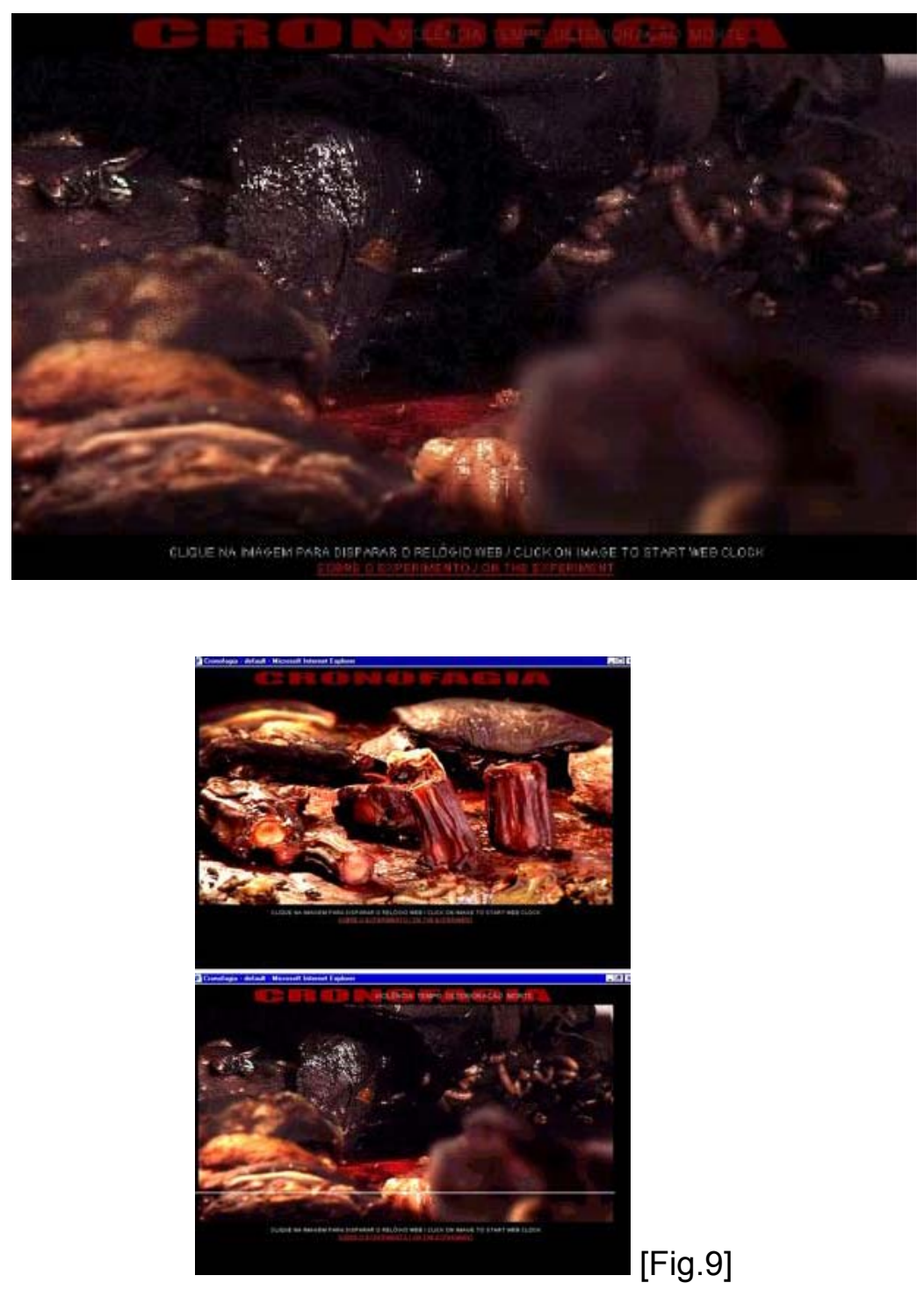

Cronofagia foi desenvolvida durante a $25^{\mathrm{a}}$ Bienal de São Paulo. O acesso ao trabalho podia se dar diretamente no endereço do site ou indiretamente através da página da Bienal. Ao clicar no nome do trabalho, o interator abre uma nova janela do navegador apenas com a barra padrão do sistema e seus respectivos botões de minimizar, maximizar e fechar. Na janela, encontra-se logo acima, o nome do trabalho com as palavras-chave "violência, tempo, deterioração, morte" que se mantêm em ritmo contínuo de esvaecer/aparecer. Logo abaixo, apresenta-se uma imagem de carne em decomposição, que ocupa uma grande parte da janela. Mais abaixo ainda, há 
instruções que incentivam a participação do usuário através da frase "clique na imagem para disparar o relógio web", e um link para outra página com um texto de algumas linhas sobre as ideias contidas no trabalho e também os créditos.

Quando a ação de ativação do relógio web é feita, a expectativa de que algo de significativo aconteça, se desfaz: somente uma linha horizontal atravessa verticalmente a imagem - referenciando uma varredura - mas a imagem continua intacta (NUNEZ, 2002).

Os autores utilizaram no site um mecanismo que contabilizava cada clique efetuado sobre a imagem, somando os cliques de todos os visitantes. Ao chegar a um determinado número de cliques - que não é informado em nenhum momento -, substituía-se a imagem até então disponível, por outra que estava a mercê do mesmo mecanismo. A título de curiosidade, podemos intuir que o número necessário de cliques para a substituição-morte da imagem seja elevado. O site foi acompanhado no período do dia 08 de maio de 2002 a 20 de junho de 2002 e, durante este período, apenas uma imagem foi substituída. Vale lembrar que parte deste período compreendeu a Bienal, o que teoricamente significa que muitas pessoas acessaram o site no espaço expositivo e através da divulgação do evento na mídia (NUNEZ, 2002a).

Em Cronofagia, o visitante é o agente - coletivo - do tempo. É ele que determina a existência da imagem exibida, sua duração e seu fim. $O$ trabalho existe em função da participação do visitante, num processo contínuo.

Cronofagia restringe toda participação a um clique sobre uma imagem e o resultado desta participação é certamente previsível: a morte da imagem. No trabalho da dupla Goifman e Müller, o processo da coletividade é oculto, invisível aos olhos de cada elemento coletivo.

Na proposta, a fotografia é usada como registro da ficção de uma cidade que apodrece, o que é igual a dizer que é usada no seu sentido tradicional em relação à memória, ainda que não seja usada de maneira típica. A metáfora parece girar aqui em torno de um conjunto de espectadores que faz com que os registros fotográficos apareçam, como se os cliques na tela obedecessem a uma releitura do ato fotográfico, da pressão do obturador.

De outro lado, que tempo é esse dos cliques que se executam sem que nada aconteça? Isto é, quase uma heresia para a dinâmica da web na qual não existe o tempo morto. O tempo no virtual resulta similar à metáfora de Borges na qual se postula 
construir um mapa em tamanho real, mas o tempo na Internet é hiper-realista. Não poderíamos, numa única vida, determos para seguir cada um dos caminhos (links) de que dispomos. Temos certeza de que lidamos com esse impossível. É a mesma que causa-nos neurose, agora online, da super-informação tanto dos eventos oficialmente atualizados pelos sites comerciais, como das múltiplas vidas pessoais que temos e poderíamos ainda ter contato na rede. Não conseguiríamos numa única vida analisar como é documentado um só segundo a partir dos milhões de olhares existentes na Internet.

Em Cronofagia o ato participativo da criação coletiva é quase impossível dada a limitação do previsível nas consequências que trará tal ação em relação à imagem. Mas da mesma maneira, sem esta colaboração dos participantes a obra não teria lugar. A única opção de participação se restringe a fazer um clique, como se tratasse de um voto. 


\section{Capítulo III: Work in progress}

No decorrer do mestrado tem se pontuado conclusões alusivas à postura local dos criadores de arte na América Latina, a posição do autor como responsável de uma comunidade virtual e a fotografia como ferramenta expressiva na Internet. Essas conclusões têm sido a base para o desenvolvimento de uma série de trabalhos que passaremos a expor neste capítulo.

3.1. Propostas colaborativas desenvolvidas com base na fotografia: Cicatrizando (2006-2009), Living Cemetery (2008-2009) e Desaparecidos (2009) 
$<\underline{\text { www.claudiasandoval.com.br/scarring.html }>}$
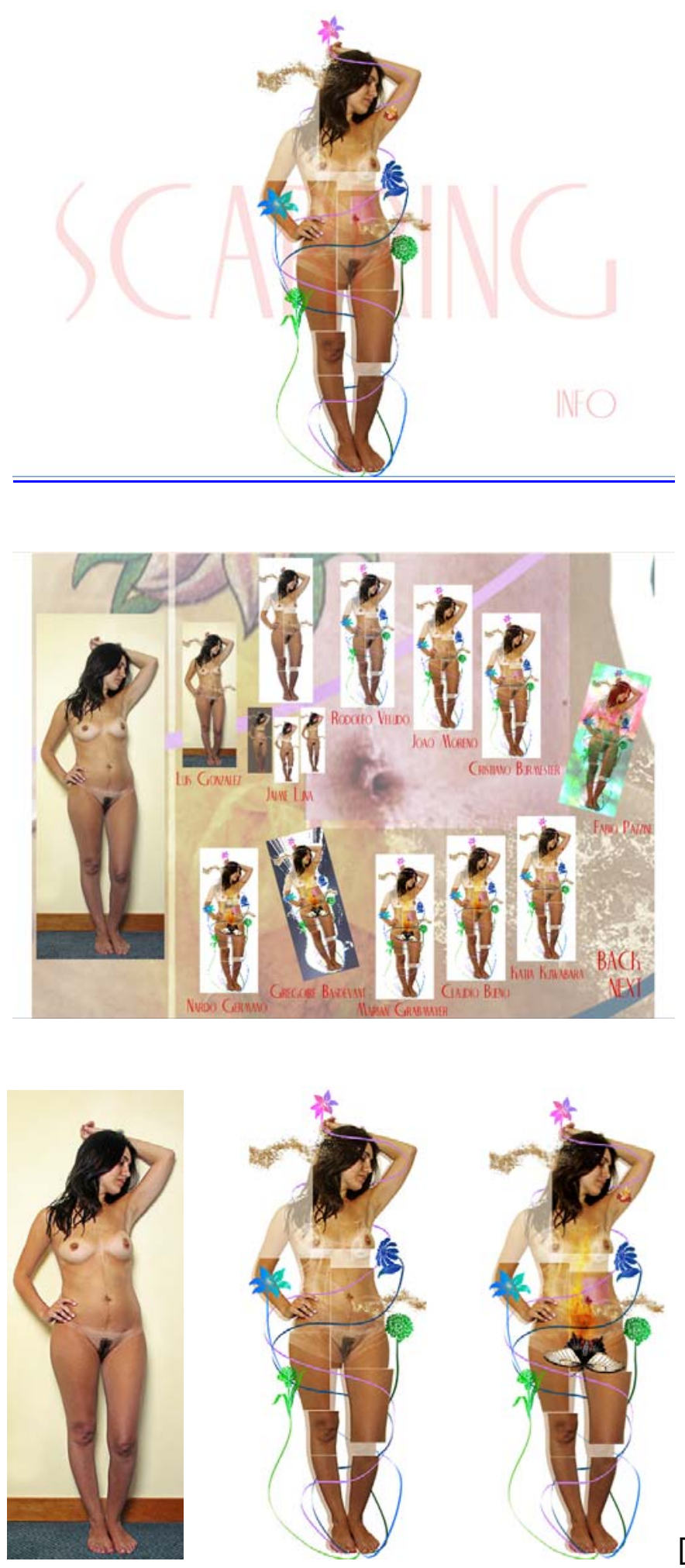

[Fig.10] 
O projeto Cicatrizando começou em 2006 e consiste em passar uma imagem via e-mail para que ser mudada pelos participantes com seus discursos pessoais. No contexto da arte colaborativa Cicatrizando é a metáfora de intervir a web com uma cicatriz já sarada. A proposta aqui consiste em esquecer o autor em contraste com todas as ações desenvolvidas quando os direitos autorais são infringidos, mais ainda ao se tratar do uso livre do nu feminino, tendo em mente o quanto a rede tem radicalizado a luta pelos direitos criativos. O trabalho suporta a ideia de um uso livre da Internet nos mesmos termos usados por autores como Pierre Lévy e Roy Ascott ao sugerir o florescimento de uma inteligência coletiva como o resultado da produção colaborativa através da rede, estendendo a consciência humana. Ao mesmo tempo Cicatrizando consiste em evidenciar a consciente perda do controle por parte da artista (SANDOVAL, 2008).

Nessa proposta se ressalta o fato de que as novas tecnologias não promoveram um avanço democratizando o acesso, universalizando as riquezas produzidas, gerando o crescimento material e cultural de todo o planeta atingindo pela sua influência (MACHADO, 2007:33). Mas elas avançaram fortemente através de figuras políticas e jurídicas como "a propriedade privada, a patente e o copyright, a hegemonia do capital global, a divisão do planeta em estratos sociais, classes, raças, etnias e gêneros diferenciados, desigualmente beneficiados com o acesso aos bens produzidos" (MACHADO, 2007:33).

Ainda que o convite a intervir na imagem esteja aberto para que os interatores a mudem como melhor quiserem, cuidando apenas para conservar a cicatriz da mulher, as propostas oferecidas até o momento têm consistido em 'cobrir' a nudez da mulher, enchendo sua pele com elementos que parecem provir das inquietudes pessoais dos participantes.

Será que esse 'respeito' pela imagem fotográfica oferecida se deve ao fato que, a maioria dos participantes são fotógrafos que ainda abraçam uma posição de sublimidade frente à fotografia, negando-se a realizar intervenções radicais que dariam por terminado este respeito?

Por outro lado, um fator participativo se lê na estrutura colaborativa que possibilita a experiência, mas esta ênfase no outro fica ainda mais marcada no website que recolhe a proposta final, já que nele se reproduzem não só os diálogos surgidos ao redor do convite e posterior intervenção dos participantes, como também se disponibilizam as páginas pessoais dos interatores através de links.

Após ter passado via e-mail a imagem para que seja transformada (no segundo momento da forma final), o do site online, pode-se falar da construção de um hipertexto surgido ao redor da ação de intervir numa fotografia, o que faz referência à construção de uma imagem híbrida, composta aqui por texto e imagem. 
A discussão sobre o corpo nu em relação ao social já tinha sido desenvolvida em ensaios fotográficos anteriores tais como A Latin American in Italy, proposta apresentada em 2007 em Fabrica, centro de pesquisa da Benetton, assim como em 2008, Intervening Bogotá. Nessas obras, as imagens de pessoas nuas invadiam pontos específicos da cidade, como se tratasse de um chamado ao pedestre desprevenido. Ambas as propostas se encontram disponíveis em $<$ http://www.claudiasandovalromero.blogspot.com/> 
$<$ www.claudiasandoval.com.br/livingcemetery.html $>$
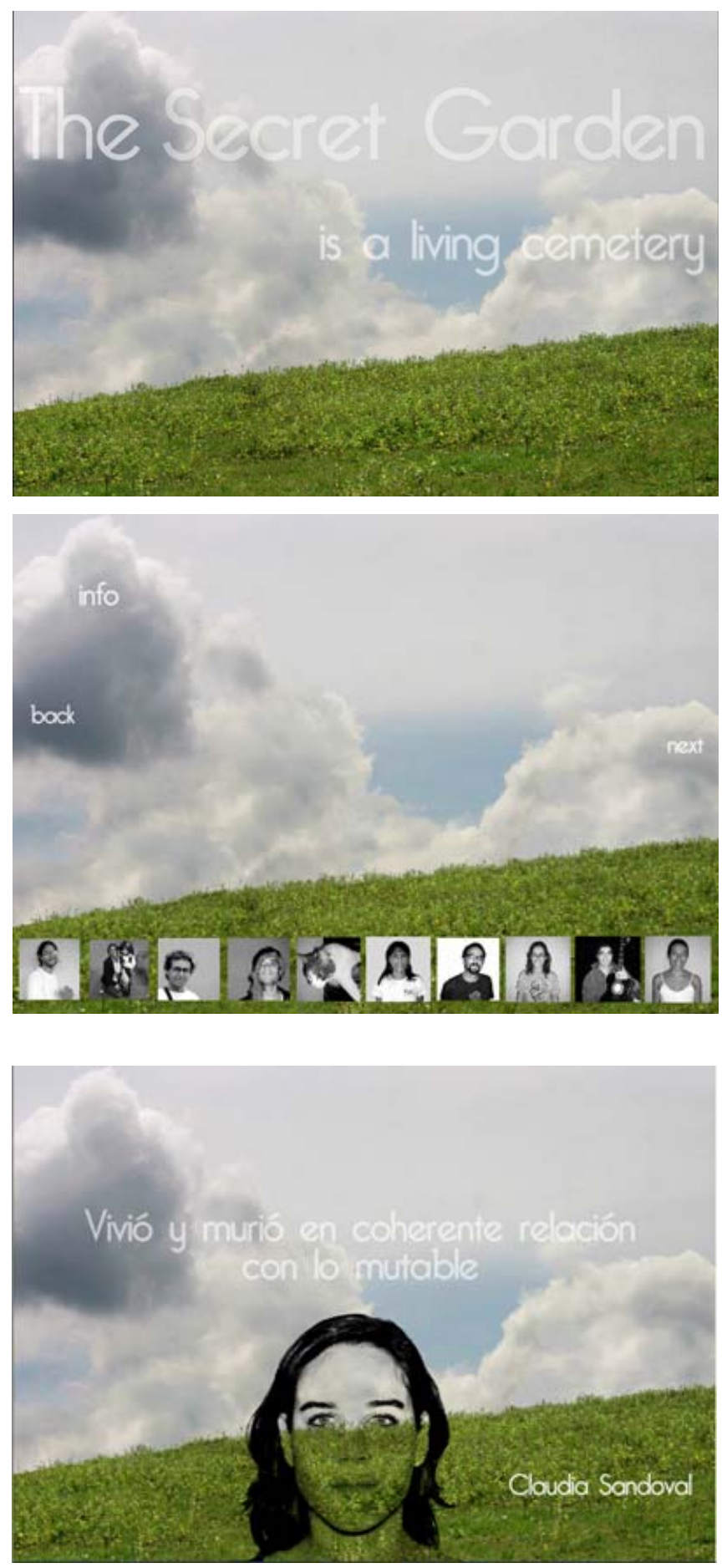

[Fig.11] 
Living Cemetery parte do pressuposto da criação coletiva de um cemitério de pessoas vivas que são convidadas a aportar uma fotografia e um epitáfio, os quais se atualizam anualmente.

Como se tratasse dos créditos de um filme da vida pessoal, os epitáfios são incorporados dentro do site na língua materna do participante, e decorrem de baixo para cima, entre o 'jardim' e o céu.

Os participantes também contam com seu próprio espaço no qual é exibida sua "última vontade". Living Cemetery funciona como um documento virtual que mesmo sem ser oficial, demonstra os últimos desejos do participante e a fotografia é usada no seu sentido tradicional: como memória, mas, neste caso, aquela memória da ficção de nossa própria ausência. Através de uma proposta de criação colaborativa, é nossa intenção refletir sobre o fato inelutável de nossa própria morte, assunto que não estamos acostumados a tratar na cultura ocidental. Talvez de alguma maneira o projeto de comunidade virtual Living Cemetery possa nos fazer assumir, de um jeito até belo, nossa gradativa desaparição no tempo, e que acontece ao lado daqueles que tivemos a sorte de compartilhar nosso tempo de vida.

Os participantes são convidados para que, de maneira sutil, façam uma denúncia das mortes injustificadas, chamando a atenção sobre o local em que está sendo construído o cemitério. Este local tem sido de Caloto, Colômbia, lugar marcado pelo conflito interno do país e pela violência (SANDOVAL, 2008a).

A proposta quer estabelecer novas relações sobre conceitos tais como a morte $\mathrm{e}$ sua estética dentro do marco da produção que se vale das novas tecnologias comunicacionais, e funciona como uma metáfora da crença de que ao morrer estaremos todos juntos de novo.

Este é um sistema social em rede, trabalhando com um grupo de amigos que se auto-suporta. Um projeto de net.arte colaborativo, pensado a partir da perspectiva da criação de uma rede de conhecimento que, de maneira poética e íntima, discute a própria morte sem a intenção de ser conclusiva. Na atualidade a ideia da morte na esfera virtual tem sido desenvolvida por sites comerciais de cemitérios ao redor do mundo, os quais oferecem um espaço virtual em memória das pessoas amadas. Algumas destas propostas são: Campoeterno.com na Colômbia, Schoedinger Funeral and Cremation nos EUA, El árbol de la Vida na Espanha, In memory of, The Virtual Memorial Garden ambas no Reino Unido, O'paradise na França, Paz Eterna, La paz e El Edén na Argentina. 
Diferentemente de Cicatrizando, onde o tempo não é um fator a ser discutido, em Living Cemetery parece ser um assunto importante, junto com a discussão sobre a morte e a releitura da fotografia, trazida para conformar novas possibilidades de comunidades virtuais.

Sermos pacotes de tempo. Deixarmos de existir no tempo e em conjunto. Adiantar-nos ao momento no qual infalivelmente teremos de dizer adeus. A dualidade aqui se constrói em torno da Internet como aquela que minimiza e faz com que quem não está dentro dela, desapareça; tanto quanto imortaliza e difunde a quem tenha a ela se aderido.

Por último, esse tipo de propostas surge como uma ferramenta para efetivamente nos aproximarmos aos outros ou, pelo contrário, não fazem mais do que nos lembrar da ausência material dos que estão longe? As novas tecnologias não estão promovendo o surgimento de um novo ser humano satisfeito com os contatos à distância, o que poderia fazer do ser humano um novo ser que se incomoda com a proximidade dos outros? 
< http://claudiasandoval.com.br/desaparecidos.html>
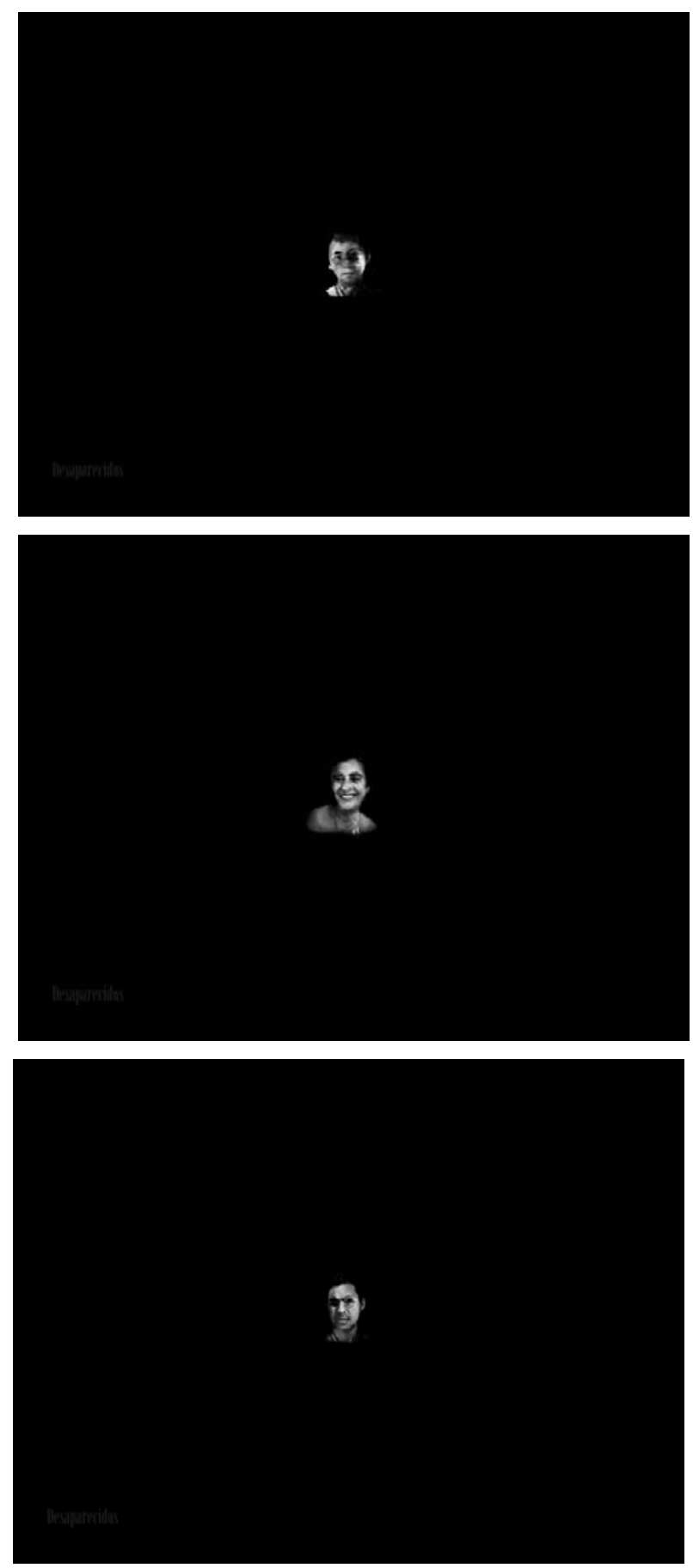

[Fig.12] 
Desaparecidos surge como resposta à violência e conflitos que têm devastado a América-Latina, gerando vítimas que, com o passar do tempo, e na medida em que as cifras aumentam, viram rostos anônimos e amorfos.

O trabalho é composto por rostos que são sempre colagens, nunca um rosto único, em constante mutação e apresentados em loop. Sobre uma tela preta, a dimensão do trabalho é pequena, sugerindo ao espectador uma aproximação intimista às imagens.

Essas imagens têm sido aportadas por sites como <desaparecidos.org> em que se procura por pessoas através de suas fotografias. Assim, o trabalho dá continuidade à pesquisa teórico-prática desenvolvida como parte do Mestrado sobre a fotografia e seus usos sociais nas esferas virtuais. Desaparecidos consiste na releitura das imagens de pessoas desaparecidas que têm sido disponibilizadas publicamente na Internet e convida à participação dos espectadores, enviando uma imagem via e-mail para nutrir a colagem.

A experimentação se encontra próxima do trabalho das morfologias de Nancy Burson, mas aqui a técnica é low-tech, enfatizando as apropriações estéticas pertencentes a contextos periféricos como o latino-americano. A ilustração grosseira ressalta o desgosto diante do assunto, vivenciado tanto historicamente por todos $\mathrm{e}$ todas, como pelo grupo de pessoas afetadas pelas ausências às que aqui fazemos referência. A partir da aproximação poética, "o feio" faz parte da representação do grotesco do assunto, não se separando do "como é feito", do que efetivamente está sendo falado.

Como se um tema pessoal se valesse da arte para se manifestar, faz-se referência ao país de origem da artista, a Colômbia, lugar onde a violência e a morte são notícias diárias e tão cotidianas que se tornam invisíveis. A violência no país gera perdas irreparáveis uma geração após outra, num processo que parece não ter fim. As imagens aqui incluídas convivem no imaginário coletivo da Colômbia e são aqui tratadas de maneira subversiva para pontuar a guerra e as perdas sem explicação que acontecem continuamente, como no loop ininterrupto de Desaparecidos.

A obra quer 'desneutralizar' a Internet sujando-a com imagens de uma realidade que não encontra muita exposição, na procura por respostas do que significa fazer arte crítica se valendo das tecnologias comunicacionais. 


\subsection{Propostas ao redor da fotografia. Passport (2008) Ovo (2009)}

São estes projetos desenvolvidos durante a experimentação prática nos quais a fotografia é problematizada sem que o peso comunicativo recaia na criação colaborativa de imagens. Neles a fotografia é o produto final da performance virtual (OVO), ou a imagem é usada como iniciativa de um debate na rede (Passport). 
<http://claudiasandoval.com.br/passport.html>
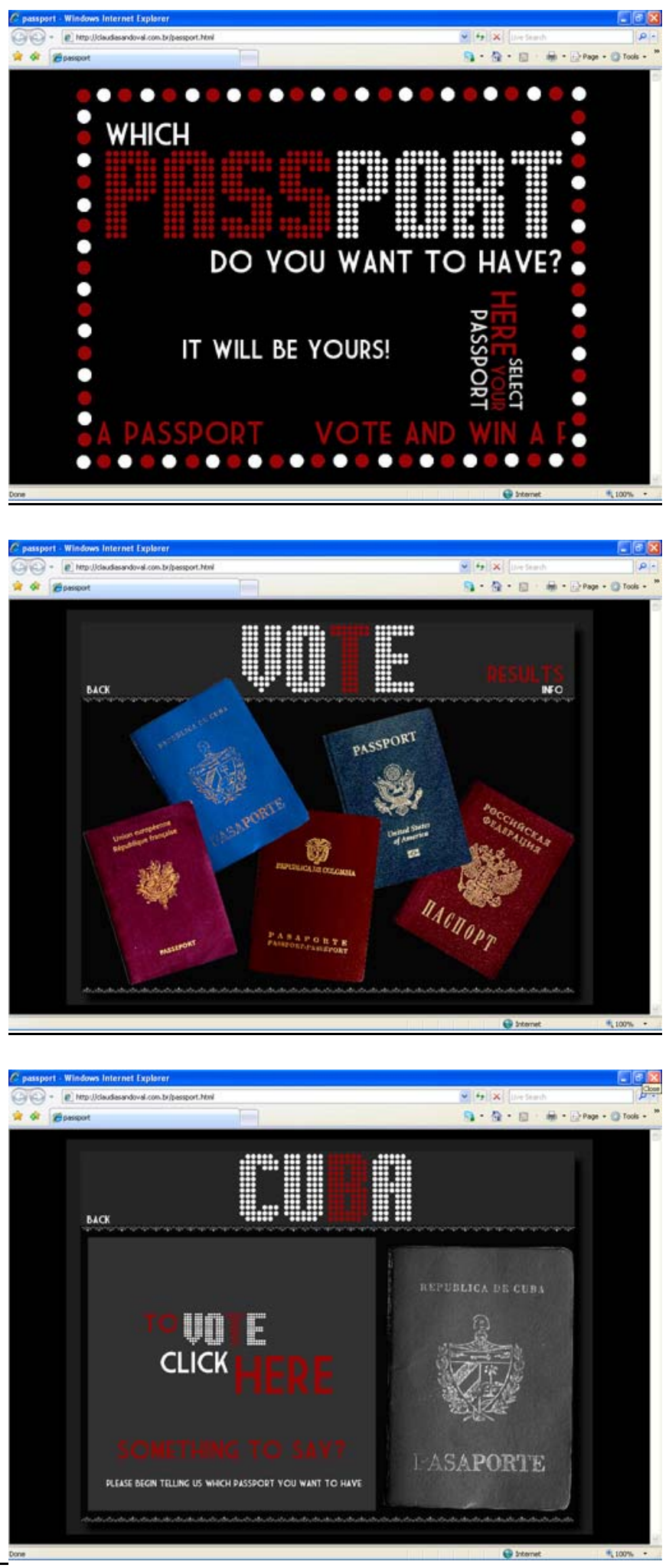

[Fig.13] 
Passport é uma proposta que consiste em um jogo falso na Internet do tipo concurso. Nele, os participantes são convidados a escolher uma entre cinco imagens fotográficas das capas dos passaportes de países de diversos continentes como França, Colômbia, Rússia, Cuba e EUA. A equipe ganhadora será aquela que pertença ao passaporte mais votado sendo que o prêmio um passaporte falsificado, de tal nacionalidade, para cada membro da equipe ganhadora.

O assunto do trabalho consiste na criação de um texto de maneira coletiva na Internet que discuta a situação atual dos trânsitos pelas fronteiras em relação ao passaporte que se tem. As indagações que trazemos incluem a escrita colaborativa na Internet.

No primeiro momento só uma referência sutil à fotografia aparece na seleção das imagens fotográficas das capas dos passaportes. Esta seleção é aquela que inicia o diálogo entre os interatores.

Nosso pressuposto em Passport é a crise da figura do autor que já foi evidenciada por Barthes,1968, e Foucault, 1969, e a proposta sugere uma estrutura de escrita colaborativa a partir da discussão ética e política sobre a mobilidade pelas fronteiras no nosso contexto contemporâneo. O projeto consiste na diluição desse autor-cabeça-única num trabalho prático para a web, ratificando a pouca importância deste autor-rei no contexto da criação contemporânea de propostas artísticas. Mais ainda, no projeto se faz evidente que a função do autor consiste mais em juntar e fazer os outros se expressarem, isto é, o autor como um aparelho comunicativo. Lembramos aqui de Beckett argumentando "'Tanto faz quem fala' alguém disse, 'tanto faz quem fala"' (apud FOUCAULT, 1969:93).

Como parte de propostas comprometidas com um marco sociopolítico que determina fortemente as condições de trabalho dos artistas da América Latina, e como parte de um trabalho que pretende fazer uma declaração crítica e radical dos problemas artísticos do contexto aplicado à produção periférica do desenvolvimento tecnológico, a proposta de Passport é dirigir a atenção à necessidade de fazer referência ao país de origem da artista, a Colômbia. Um país economicamente em colapso e cuja história tem sido marcada pela violência e a guerra, o que define sua posição em relação ao resto do mundo, permeando assim a movimentação de seus habitantes fora do território nacional.

De outra parte, a proposta quer enfatizar nas ideias do geógrafo Milton Santos (2000) sobre as novas permissões de transitar em territórios virtuais que tal parecem 
conectar os centros hegemônicos deixando de lado, isto é, isolando e fazendo cada vez mais invisíveis as periferias. Cabe aqui nos perguntar pelo paradoxo de um mundo interconectado cada vez mais pelas novas tecnologias comunicacionais em contraposição à crescente rigidez das normas para que pessoas, dos países economicamente subdesenvolvidos, não consigam ultrapassar as barreiras físicas nacionais, impedindo-as de circular pelos países economicamente fortes.

Passport polemiza a partir de uma estética low-tech as questões anteriormente mencionadas por se valer de um blog como forma final.

Este é um trabalho que se localiza ao lado de Looking for a Husband With a EU Passport, (<http://artefact.mi2.hr/ a01/lang en/art ostojic en.htm>) , proposto pela artista da Yugoslávia Tanja Ostojic e a proposta homônima Passport, (<http://artefact.mi2.hr/ a01/lang en/art kuluncic pass en.htm>) , de Andreja Kulunčić.

Essas propostas apontam para o fato de que o passaporte tem se convertido no fetiche do século $X X$, e constitui a base da segregação nas fronteiras territoriais. "Sobre Marx, Jesus e Buda. Se eles estivessem vivos hoje, só Marx teria um passaporte desejável e seria capaz de caminhar pelo mundo sem restrições" (KULUNCIC apud KALCIC, 2009).

A proposta também considera o desenvolvimento de um segundo momento no que possibilita às pessoas vivenciarem a experiência de ter o passaporte escolhido. Através do upload de uma fotografia e dos dados pessoais dos participantes, um programa geraria uma imagem virtual final do passaporte falso selecionado. 
<http://claudiasandoval.com.br/ovo.html>
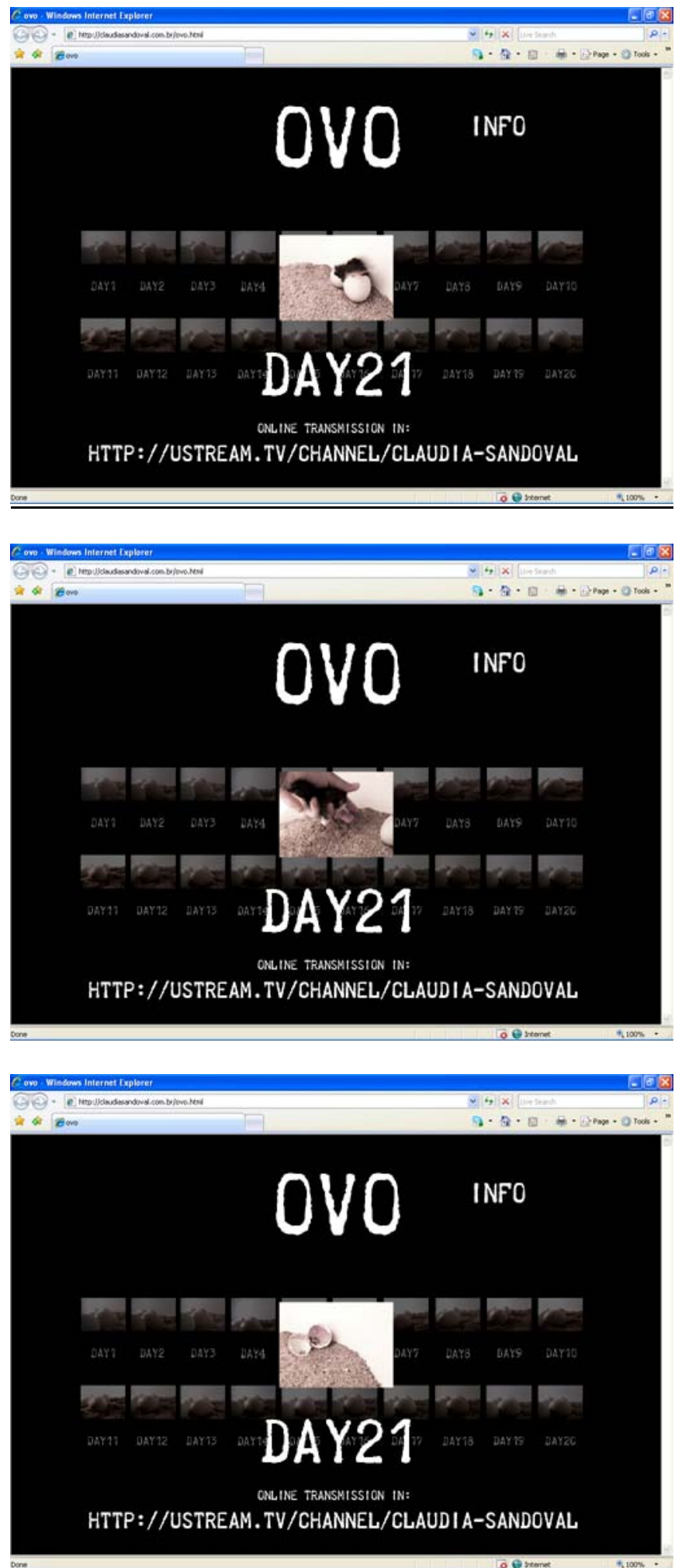

1. O reane

[Fig.14] 
OVO consistiu na transmissão online e em tempo real dos 21 dias que demoram para que dentro de um ovo se origine a vida.

Nos anos 1980 Bill Viola gravou em vídeo o nascimento de um pinto questionando as possibilidades expressivas da nova mídia. Aqui é oferecida uma releitura sobre a ação de Viola levando a discussão ao fator temporal, comparando-o com o 'sempre-acelerado' tempo vivido dentro da Internet. Isto em contraposição aos tempos que demoram alguns processos, neste caso a gestação da vida.

A realidade virtual pede por resultados imediatos, obrigando-nos a viver de maneira mais rápida. Os novos marginalizados das tecnologias, como a Internet está criando são aqueles incapazes de acompanhar o requerimento de rapidez, como nota Eugênio Trivinho (2007). A nova matéria que nos divide, e contra a qual devemos lutar é o tempo.

No projeto também se explicita a premissa Nietzschiana acerca do "torna-te o que tu és" como um processo oculto do olhar humano, como um período de tempo incontrolável e impossível de ser forçado ou acelerado. Esse argumento serve de bandeira para marcar a Internet como o lugar que, devido a suas dinâmicas internas, parece desprender o ser humano do orgânico.

Em OVO, o paradoxo do tempo lento e necessário que alguns processos requerem, tem sido jogado a viver junto com a nova dimensão temporal desenvolvida a partir das novas tecnologias. Como afirma Giselle Beiguelman (2008) sobre aqueles usuários da web que censuram as novas práticas sociais na Internet

Será que eles ainda não se deram conta que o ano de 365 dias é gregoriano, que o dia de 24 horas é oitocentista, que não existe este prazo de validade on line? (BEIGUELMAN, 2008).

OVO quer também questionar as tecnologias como a Internet, ferramentas que fogem da procura pelas respostas às perguntas que têm inquietado desde sempre o ser humano. 
3.3. Propostas ao limite da fotografia. Coyote (2009), Caloto (2009) e Sammlung (2010)

Outras propostas nas que a fotografia não é direitamente analisada, mas que trazem conclusões do processo de pesquisa, são Coyote, Caloto e Sammlung. 
<http://www.claudiasandoval.com.br/coyote.html>
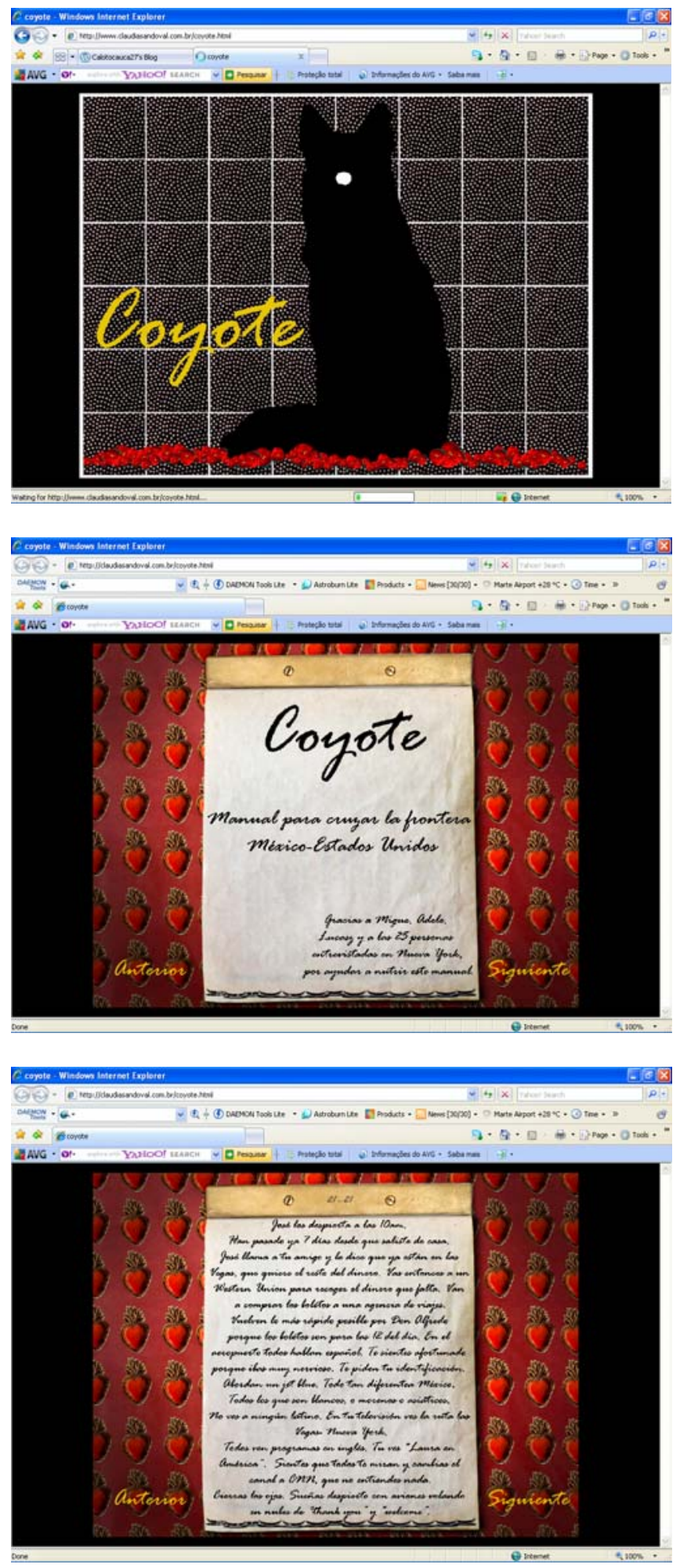

[Fig.15] 
A partir de 25 entrevistas desenvolvidas nos Estados Unidos, criou-se este manual online para cruzar a fronteira. Coyote questiona os limites da arte em relação à legalidade, sendo este um conceito inconsistente da sociedade contemporânea.

Para alguns, o coiote simboliza perfídia, para outros significa imaginação, independência e uma poderosa vontade de sobrevivência. $\mathrm{Na}$ área da fronteira entre os Estados Unidos e o México o termo coiote também se refere a um tipo muito especial de ser humano: os traficantes de imigrantes que, por uma taxa, oferecem seu conhecimento sobre como cruzar a fronteira sem estar com a papelada exigida (SCHNEIDER, 2000).

Coyote aparece como um manual para evadir o horror, oferecendo maneiras paralelas de cruzar a fronteira e ter sucesso no processo. $O$ trabalho questiona a ilegalidade no contexto cultural contemporâneo, conceito que aparece como representação do repudio pelos imigrantes, mas que inclui certa tolerância deles dependendo da ocasião. 
<http://www.calotocauca27.wordpress.com/>
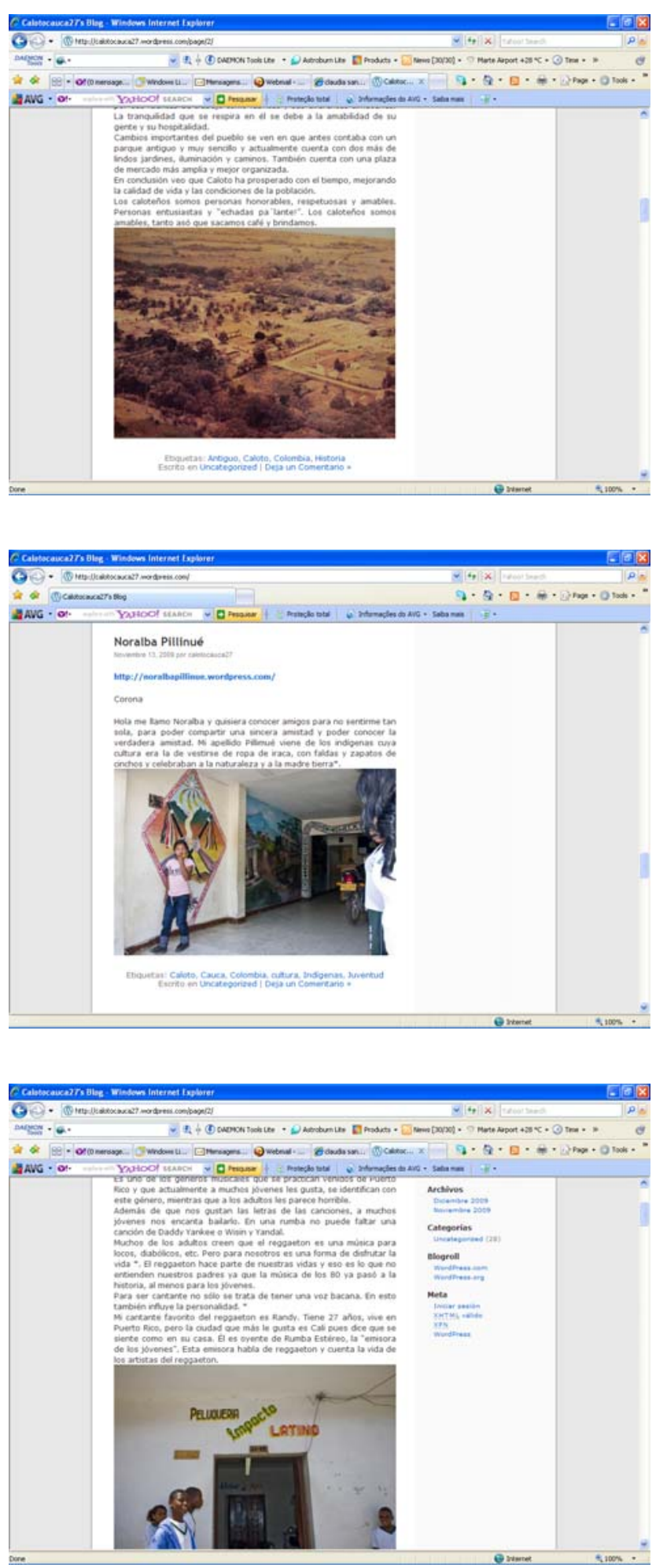

[Fig.16] 
O Projeto Caloto consiste na elaboração de blogs por parte de uma comunidade de adolescentes de Caloto, município rural da Colômbia. Aqui a criação de uma série de blogs gera novas aproximações a uma zona fustigada pela violência. Aqui as ferramentas para a criação de propostas de arte coletiva são deixadas nas mãos da comunidade convidada a participar, sem maiores intervenções.

Caloto leva à prática a posição mais radical de compromisso do autor que trabalha com comunidades virtuais. A proposta tira a arte do institucional e a aproxima de sua manifestação social mais evidente. O projeto leva a arte até o limite da não-arte.

Caloto consistiu em um workshop de fotografia, escrita e blogs, desenvolvido com os adolescentes da comunidade, a partir da crença de que as propostas artísticas mexem diretamente com o social até o ponto de conseguir, mesmo a partir do metafórico, transformá-lo. Arriscou-se aqui a levar o ensino como ferramenta expressiva da arte na Internet para a posterior criação coletiva de um texto em que os sonhos, a violência, a juventude e as oportunidades (ou não), se tecem à vontade nos posts dos participantes. 
<http://kah-bonn.co.de/>
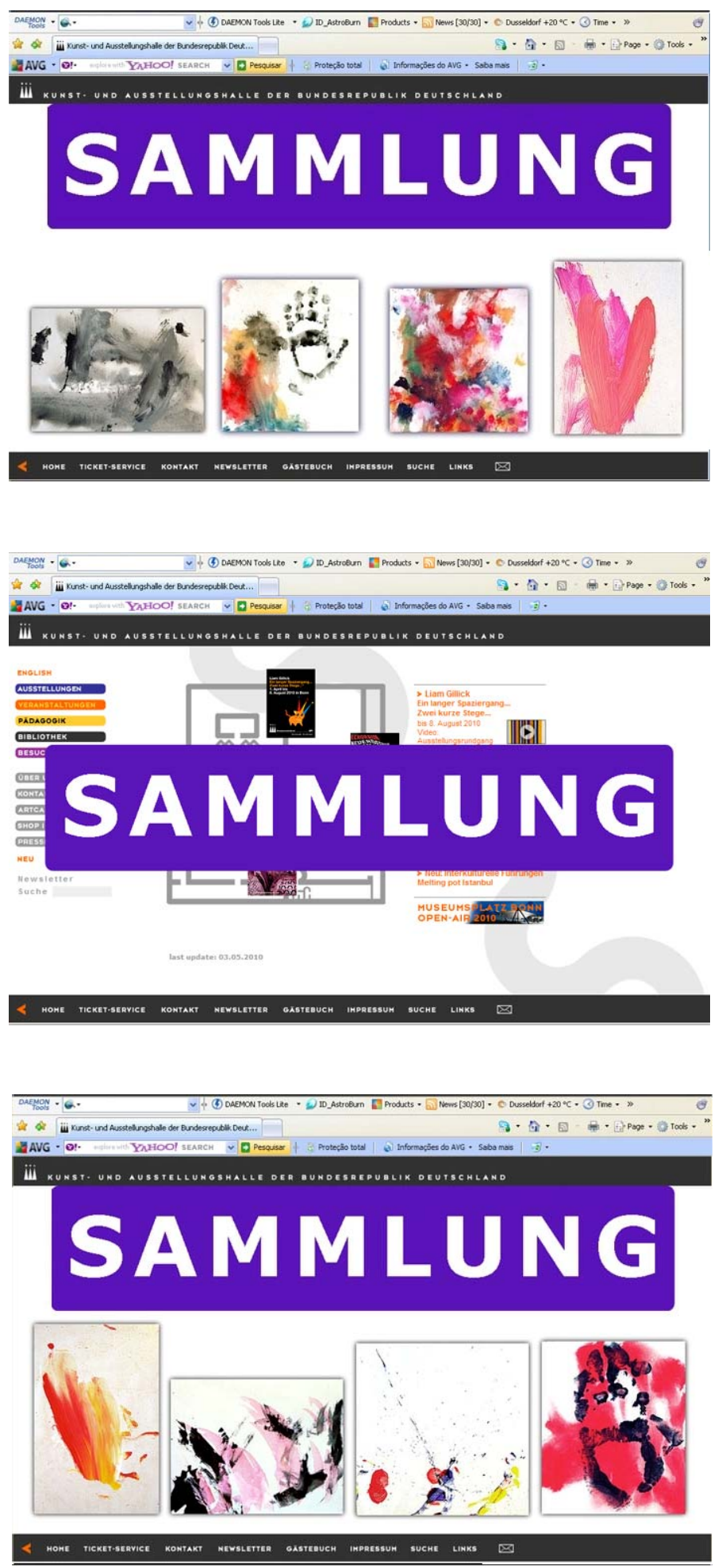

[Fig.17] 
Sammlung - que em alemão significa coleção - consiste na criação de uma imagem espelho do website do museu KAH da cidade de Bonn, Alemanha. O website consiste numa série de peças produzidas por animais que fazem parte do acervo do museu. A performance acontece como uma ação virtual de guerrilha usando a ideia dinâmica do museu como instituição da arte, criando uma nova realidade do mesmo na esfera virtual. Assim, uma invasão sutil na Internet de um site falso do museu, isto é, a publicação de uma imagem que é recriação irônica, acontece fazendo com que seja o próprio museu a peça artística. 
3.4. Propostas locais em ambientes internacionais. Lost Memories (2010) e Holograms of Deportation (2010)

Estes trabalhos foram desenvolvidos durante o intercâmbio com KHM Kunshochschule für Medien Köln, durante os meses de abril, maio, junho e julho de 2010. O objetivo do intercâmbio consistia na produção de propostas em arte das novas tecnologias, mas matizando-as com as particularidades de conflitos que atingem menos o global e mais as periferias econômicas. Foi assim que se deu ênfase na problemática das deportações. 
<http://www.claudiasandoval.com.br/lostmemories.html>
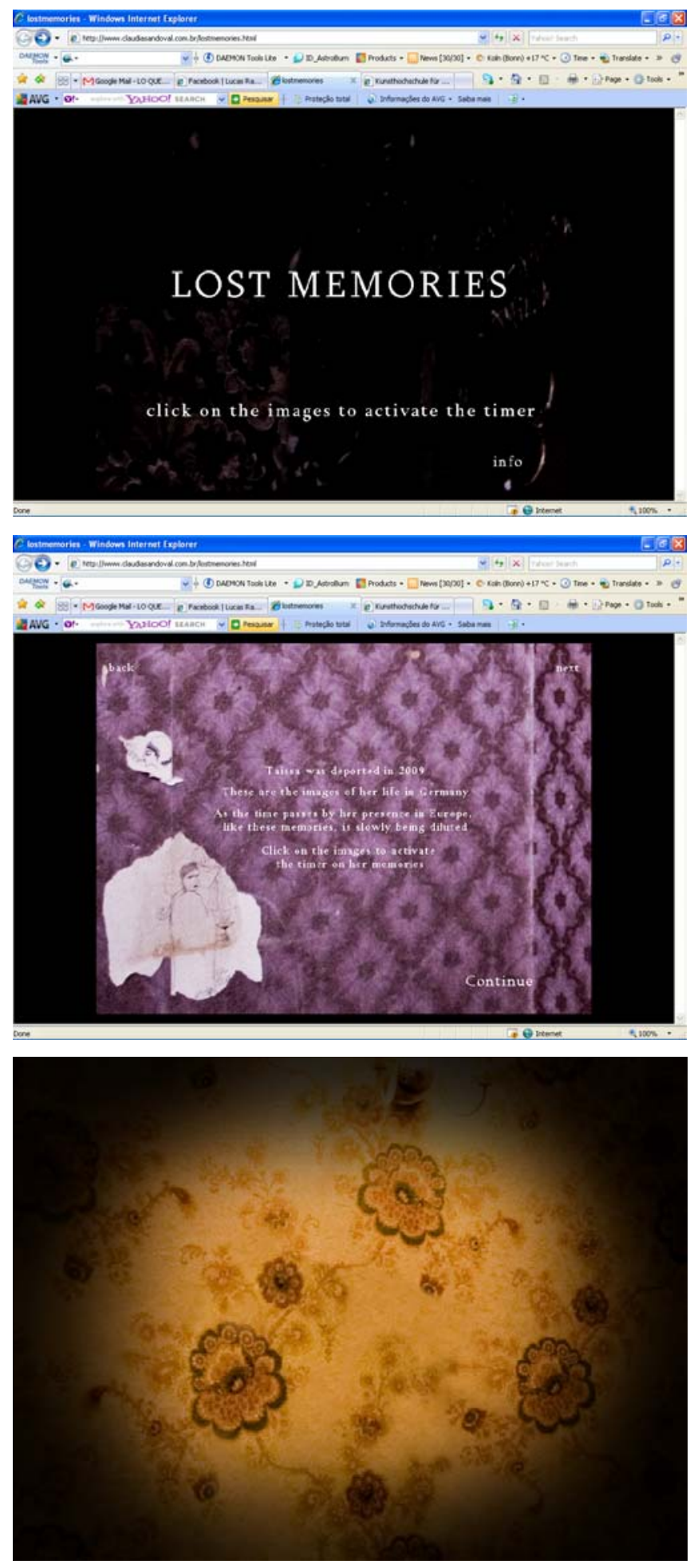

[Fig.18] 

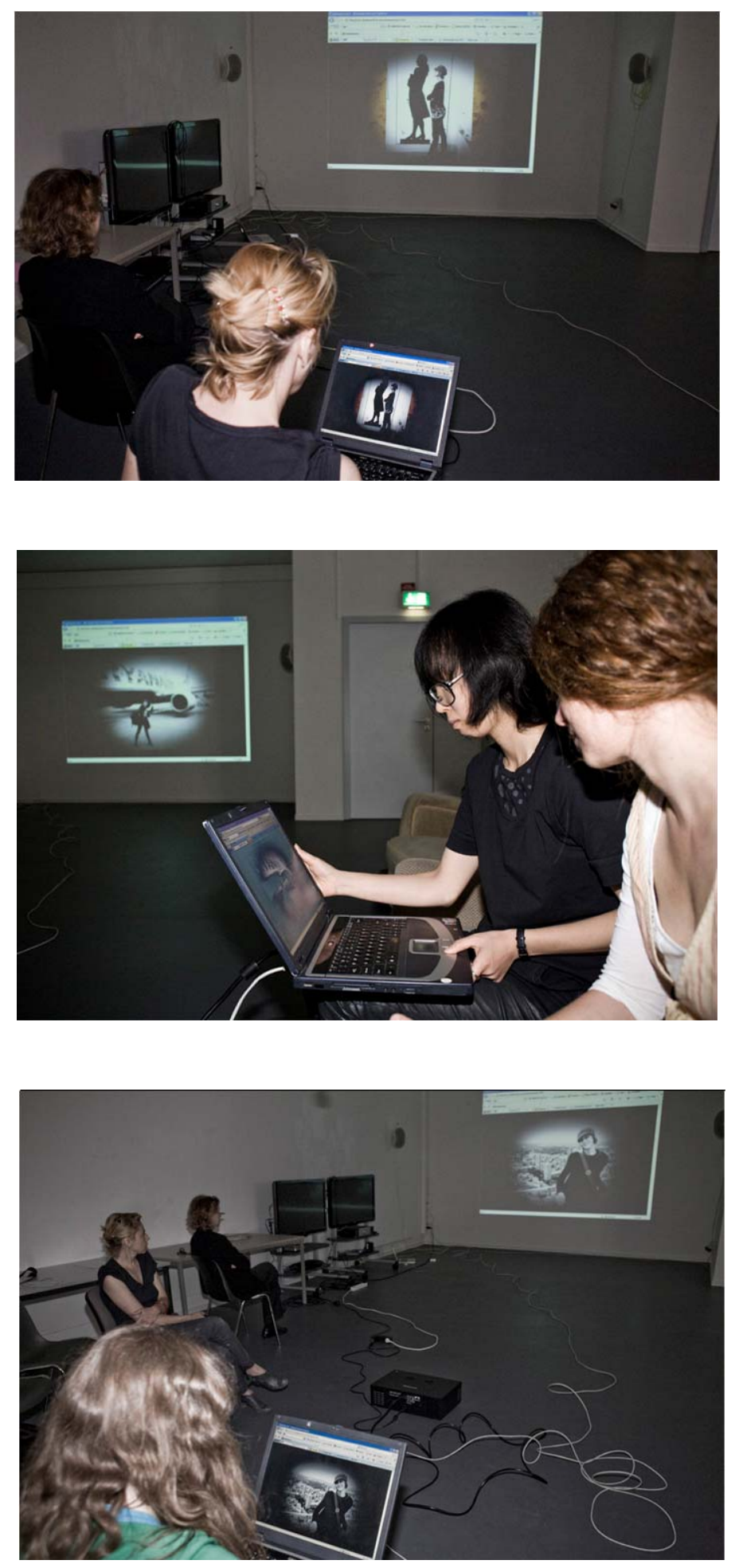

[Fig.19] 
As lembranças da vida de Taíssa, uma jovem brasileira, formam um filme na Internet. A peça foi criada para que nela se intervenha na Alemanha, local de onde Taíssa foi deportada em 2010. Assim, pedeu-se aos interatores que ativassem o tempo das lembranças de Taíssa.

Um por um (numa performance ocorrida no dia 22 de junho na KHM, em Colônia, Alemanha), os interatores clicaram sobre o filme da vida da Taíssa sem que nenhuma mudança acontecesse. Desapontados, desapontadas, queixaram-se de não ver resultado imediato no projeto. Poucos minutos depois, as imagens sobre as quais clicaram desapareceram do filme na Internet.

Mesmo disponível na Internet, só os interatores na Alemanha conheciam e tinham acesso ao projeto. Os participantes faziam com que o fator tempo atuasse nas imagens, desvanecendo-as. Através de um script desenvolvido para flash, as imagens desapareceram do FTP em que se encontravam alojadas. Os interatores participavam ativamente da desaparição das lembranças da Taíssa, da mesma forma que ao se tratarem de simples espectadores passivos, sua ação parecia cooperar com a situação das deportações.

O projeto questiona a obrigação do tempo real para os trabalhos na web. Questiona também a expectativa de que alguma coisa deslumbrante aconteça para satisfazer o desejo de comprovar as habilidades do webdesigner. Aqui nada acontece diferente da tradução para um ambiente virtual, da vida de uma deportada que está se perdendo com o tempo e em silêncio. Aqui nada acontece diferente à não-construção, mas sim a desaparição de uma peça de arte para a Internet.

Por último, a ação colaborativa consiste na apropriação das imagens da vida da Taíssa, do mesmo modo que, sem a ação colaborativa dos interatores na Alemanha, o trabalho não acontece. É graças à colaboração deles que a poética ocorre. 
<http://www.claudiasandoval.com.br/hologramsofdeportation.html>

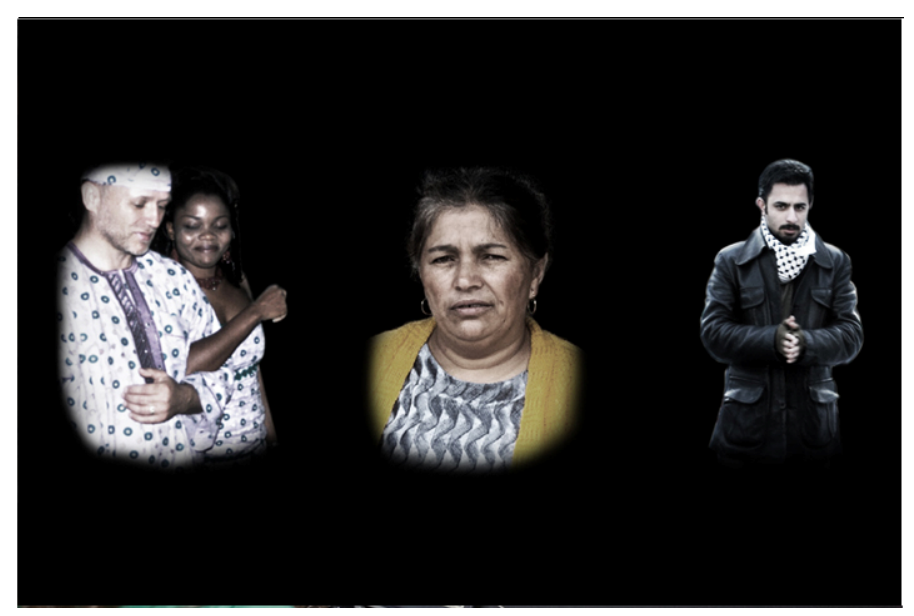

[Fig.20] 

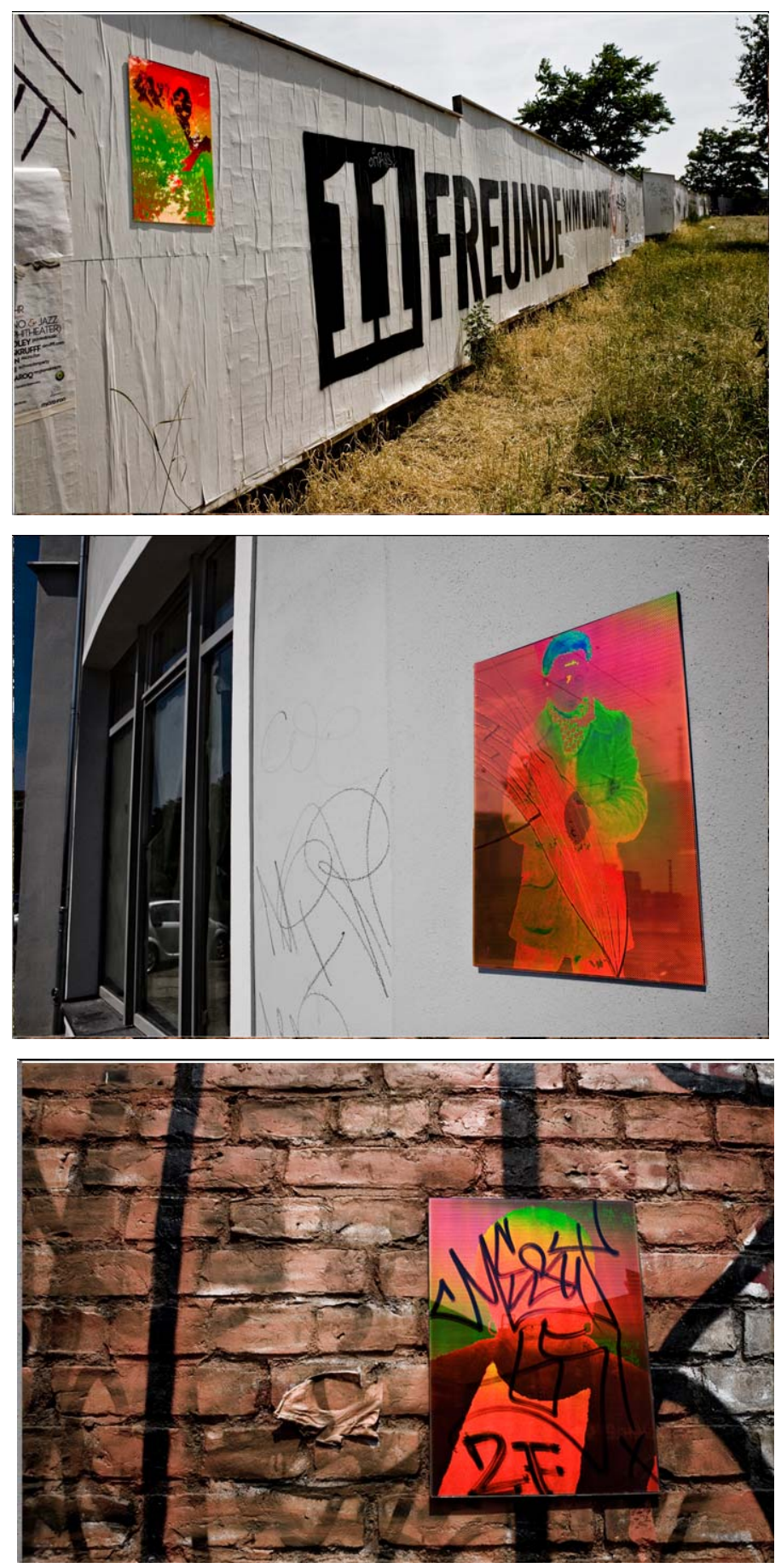

[Fig.21] 
Holograms of Deportation foi produzido após a entrevista com Ernst-Joachim Odrowski, diretor do Departamento de Deportações de Colônia, Alemanha. Na entrevista, foram destacados os locais de maior imigração na região de Colônia, como o norte da África e a Turquia.

Assim, três retratos de deportados são tomados da Internet e com eles se criam hologramas Dot Matrix.

As pessoas dos retratos são Rose Ekhator (Nigéria) e Jörg Mückler de Wünschendorf. Eles dizem na Internet: Estamos juntos desde 2002. Minha mulher foi deportada em Fevereiro de 2005. No seu país ela perdeu nosso filho em Maio. Nós casamos em Junho e começamos a convencer a embaixada alemã que nós somos um casal 'real' (MÜCKLER, 2005).

Da mesma maneira aparece na Internet o caso de Engin Celik. Consiste em: Durante uma viagem em trem desde Frankfurt até Düsseldorf em Janeiro 7, 2007, ele foi levado preso por um oficial da polícia, próximo de Gießen e foi levado à cadeia JVA Gießen. Foi avisado então para ele que seu procedimento de asilo foi decidido negativamente e que ele seria deportado. Em Janeiro 15 Ergin Celik entrou em greve de fome para protestar contra à privação de sua liberdade e contra a intenção das autoridades alemãs de enviar ele de volta na Turquia. Ele foi finalmente deportado (KARAWANE, 2007).

E finalmente, no website do Council of Europe, o caso de Krasnici Kadira, cigana nascida em 15 de julho de 1958 que foi deportada da Alemanha com seu marido após 16 anos morando naquele país (COUNCIL OF EUROPE, 2009).

Desta maneira, os hologramas são levados para a capital da Alemanha, Berlim, trazendo de volta a presença destes três casos de deportações que servem de exemplo para ilustrar a problemática inteira (toda a problemática).

Como um chamado gritante os hologramas repousam sutilmente sobre os muros de Berlim até que a luz solar os toca direitamente em ângulo de 90 graus. Neste momento o que repousava tranquilo fica com cor vibrante, e se transforma em rostos que podem ser vistos somente através de certa distância.

O abandono desses retratos na rua é transmitido numa performance pela Internet, num movimento que vai da Internet à realidade e volta novamente a seu origem.

O trabalho foi apresentado durante a exposição da KHM Jahresausstellung Rundgang 2010 e nela o registro fotográfico da performance em Berlim é deixado sobre 
as grades de uma igreja próxima à instituição como se o próprio trabalho fosse um chamado de atenção, em busca dos deportados. Da mesma maneira, o trabalho participa de uma exposição em Wuppertal, Alemanha, em agosto de 2010, deixando nas portas da galeria os últimos registros dos Dot Matrix Holograms, que, pichados e destruídos, 'olham' através das janelas para a rua. 


\section{Considerações Finais}

\section{Desconstrução da autoria e desautorização do(a) autor(a)}

Nesta consideração sobre a autoria e a arte da Internet ressaltamos a importância de assumir de outro jeito a desaparição do autor, mais como um chamado para que este autor se abra conscientemente à participação dos outros em suas propostas colaborativas.

Como tratamos no texto, não é possível a geração espontânea de peças de arte na Internet nas que desaparece o autor.

A quantidade de autores que fazem as propostas não é equivalente ao número de participantes da peça. Assim sendo, isto seria criação coletiva de iguais e não é isso o que se espera das propostas para a Internet nas que o contato com 'mais diferentes' se potencializa. Por outro lado, sempre há um autor entre os autores, isto é, uma figura que define, mesmo que seja sutilmente, a proposta.

Desse modo, a figura do autor é ainda necessária para que a proposta seja acolhida na instituição artística na qual ainda vale a definição de arte como aquilo que é feito pelos artistas. Mas o "como fazer arte" mudou nas esferas virtuais como a Internet e se pede que o autor desapareça e permita aos participantes se expressarem. É nesee processo de desaparição que o autor deve se apropriar do compromisso com a sociedade à qual representa, sendo crítico com seus pontos de vista individuais e com as metodologias, se aproximando das problemáticas sobre as quais fala. Assim, como num paradoxo, na desaparição do autor este não desaparece, muito pelo contrário, pede-se que ele assuma sua desautorização e procure os benefícios da comunidade.

A sensibilidade individual do artista é ainda fundamental para a criação de peças artísticas no contexto tecnológico da produção para a Internet. Nossa sugestão consiste em propor que o autor que usa a Internet construa uma postura crítica e reflexiva de si, mas do que nunca antes. Que reflita por fora dele contrastando seus pressupostos sensíveis com os da comunidade que responde pela elaboração da peça artística porque sua técnica o põe em contato com outras realidades diferentes à sua.

Por outra parte, no contexto da criação em mídias como a Internet, não é suficiente que o artista seja somente o medidor da sensibilidade coletiva e que, a partir da própria sensibilidade do artista como individuo, se produza seu trabalho. Após analisar os processos de criação da arte contemporânea que trabalham com a Nova Tecnologia Comunicacional da Internet, entendemos que propostas nas que o autor fica efetivamente mais invisível -leia-se o artista- ou que são interessantes como fenômenos 
sociais que representariam o contexto contemporâneo, sem que se tratassem da maneira acostumada de ler e entender a arte não teriam como continuar sendo excluídas hoje daquilo que definimos como a arte mesma. Assim também, e como retroalimentação deste fenômeno, a maneira de fazer arte mesma pode ver-se afetada pelo contexto contemporâneo não só desde a apropriação das técnicas que este novo contexto lhe oferece, mas seria interessante ver mais peças dentro da instituição da arte em que metodologias de outras áreas sejam implementadas, contanto que o autor submeta seu ponto de vista ao aval da comunidade com a qual cria conjuntamente. Isto como uma conseqüência de ter o artista agora como nunca antes, em contato com um público mais amplo e variado, aquele que tem acesso às peças na Internet.

Propomos então abrir o leque da criação extravasando os limites impostos pelas instituições artísticas, como uma consideração às particularidades da criação colaborativa em esferas virtuais. É assim que pensamos na inclusão nestas novas possibilidades de criação as propostas onde os métodos de construção de um discurso sejam relevantes para e pela sociedade representada.

Por último, cabe ressaltar o cuidado ao tratar da desaparição da autoria em prol de uma comunicação na que mais autores podem hoje se expressar, como demonstrada a produção livre e massiva de blogs (LEMOS, 2002). Na liberação da autoria em prol de uma comunicação mais abrangente em que todo mundo pode ser ouvido corremos o risco de confundir o "todo mundo" com o "ninguém" e isto leva a pensar em que se "todos" estamos falando, não tem "ninguém" efetivamente nos ouvindo. No desaparecimento da dupla autor-leitor como explica Wolley (apud LEMOS, 2002), enfrentamos o perigo de sermos todos autores para leitor nenhum, ou melhor, de sermos um tipo de sociedade preocupada com a emissão de informação em detrimento das capacidades de leitura e assim, da comunicação efetiva. E isto caberia como uma questão mais geral sobre a apreciação de peças de arte para a Internet. 


\section{Autoria e rede}

Nesta consideração sobre a Autoria e Rede ressaltamos o fato de que a criação dentro da Internet não reúne a diversidade que potencialmente se esperaria que reunisse.

A criação em rede na qual se juntam saberes e visões realmente diferentes acontece ainda majoritariamente na teoria e não na prática já que as 'enormes minorias' ficam por fora pois não conseguem atingir a web. Assim, é só uma parte muito reduzida que o trabalho coletivo na web considera e esta porção de pessoas compartilha o jeito particular de experimentar o mundo (GARCIA DOS SANTOS, 2003, TRIVINHO, 2007, MACHADO, 2007). Desta maneira, ainda é possível potenciar a junção de saberes realmente variados nas criações coletivas para a Internet se quisermos realmente falar de criações coletivas e de junção de diferenças.

É por isso que chamamos a atenção para uma criação em rede que se aproprie realmente das vantagens oferecidas pela ferramenta comunicacional Internet. Para que as problemáticas e debates próprios das regiões periféricas que têm ficado por fora neste processo de acessos também tenham seu espaço. Para conseguir chamar à criação coletiva efetivamente de diversa, insistindo na inclusão de sensibilidades que vão até em contra da Internet ou que são constantemente deixadas por fora.

Por outra parte, reunir diferenças, isto é, pôr-se em contato com o 'outro' sempre gera tensões e conflito. Assim, as dinâmicas sociais no interior da Internet têm desenvolvido mecanismos de anulação do diferente e de separação dos 'inimigos' ${ }^{6}$. Cabe nos perguntar se a reunião verdadeira dos opostos no virtual não teria gerado um colapso da máquina intercomunicante da Internet, isto é, uma guerra a mais, como conseqüência das diferenças irreconciliáveis que são jogadas para morar uma do lado da outra.

Por que não temos uma guerra virtual se, como nos têm convencido, na Internet existem todas as condições para que se aconteça? Se a Internet ainda não colapsou talvez se deva a que temos criado efetivamente barreiras de encontro das diferenças,, ou a razão mais forte ainda seja que nem todos estamos sendo representados no

1 Em uma palestra sobre fotografia, Giselle Beiguelman falava do "capitalismo fofinho" com o qual convivemos cotidianamente nas redes sociais como o Facebook e o Orkut (Semana da Fotografia Fnac, São Paulo, 2008). Cabe ressaltar que o uso deste "capitalismo fofinho" implica deixar por fora os inimigos. Eles não pertencem a nossa rede e criamos uma fortaleza virtual que nos isola não somente deles, como também do diferente. 
interior da rede. Ou talvez possamos mudar de perspectiva e começar a chamar de nova guerra aos vírus e às ações dos hackers?

Assim, retomando a criação em rede, para que a produção de conhecimento seja criada em coletivos mais potencializados onde se juntem as competências, há necessidade de que a partilha não implique no fortalecimento de estratégias de domínio econômico. O trabalho em rede pode estar fortalecendo as estratégias de domínio econômico, reforçando-o sem que isso seja claro. É por isso que se faz necessária uma aproximação crítica à noção de trabalho em rede, sendo esta aproximação um item importante a ser considerado pela arte como contribuinte parte do contexto social. 


\section{Algumas problemáticas da arte da web}

Descrevemos nesta consideração algumas problemáticas a serem consideradas pela arte da web quando as novas tecnologias são apropriadas por artistas que produzem desde as periferias econômicas.

A partir do uso das NTC as mudanças na percepção estética estão sendo potencializadas pela arte como nunca antes. É por este motivo que é relevante uma aproximação crítica no trabalho de arte feita em redes como a Internet. Assim, faz-se importante que os artistas da América Latina que trabalham com a rede Internet reconheçam que se estamos inscritos no novo universo comunicacional, nossa aproximação se faz a partir da periferia.

$\mathrm{Na}$ sociedade atual, a norma ideológica trata de reificar e neutralizar as pessoas ao invés de humanizar as coisas. Uma sociedade em que as estratégias fiduciárias e de manipulação ganham a luta da ação política. Na qual a manipulação das pessoas é colocada acima das ações e se manipulam as coisas como se elas fossem pessoas. Enfim, é esta uma sociedade onde as estratégias operacionais ou de manobra se fazem em função de manobrar as pessoas como se fossem coisas (PARRET, 1997). Num contexto de políticas econômicas cruéis nas quais as novas mídias comunicacionais oferecem ferramentas para que isto se fortaleça cabe nos perguntar o lugar da arte em relação a meios como a Internet para se deter a determinar nos perigos de que a arte mesma fortaleça a nova economia excludente.

Por outra parte, a arte das NTC se enfrenta também ao fato de que a sobrevivência passa hoje obrigatoriamente pela capacidade que os indivíduos e populações têm de se inserir no mundo das máquinas e de acompanhar as mudanças da evolução tecnológica (GARCIA DOS SANTOS, 2003:10). A comunidade científica latino-americana na qual incluímos a arte ainda não despertou para a particular gravidade "da situação histórica fundada na informatização e virtualização generalizadas dos processos e relações sociais" (TRIVINHO, 2007:135). Como ressalta Eugênio Trivinho (2007), precisa-se da desconstrução da cultura midiática avançada. Está ela órfã de qualquer sinal social e político de solução a curto, médio e longo prazo, permitindo que o neoliberalismo estatal e empresarial, a globalização de trocas econômicas e financeiras, e o advento de uma hierarquia invisível baseada na lógica dos acessos e as formas intensifiquem a segregação social (TRIVINHO, 2007:135). É nesse contexto em que se produz a arte das tecnologias comunicacionais hoje, na qual é imprescindível discutir também o papel da arte no contexto institucional e na 
sociedade. Essa discussão é pertinente para não cair no trabalho ingênuo que se colabora com manipulações mais abrangentes, o que poderia deslegitimar a função mesma da arte.

Faz-se necessário que a arte das NTC considere seu contexto hoje mais do que nunca, por estar ela mais em contato do que nunca antes com um amplo grupo de participantes. Assim, ela deve encontrar seu próprio caminho para se apropriar da nova tecnologia sem desconsiderar fatos tais como de que "todos estamos cada vez mais perto", como se verifica com a desaparição do último pombos- correio na Índia em 2001 e na comunicação via Internet que os indígenas de diversas localidades sustentam na atualidade. Tal é o caso dos índios Xingu que usam a Internet para construir um sistema alternativo de comunicações entre as nações indígenas do Pará, assim como os camponeses de Chiapas que usam a web na procura de adeptos à causa zapatista contra o governo mexicano, ou os índios norte-americanos que trocaram a skywriting, ou linguagem dos sinais, de fumaça pela netwriting. É inegável após ter sido fechado o último pombos- correio em Orissa, na Índia, em 2001, que os processos de globalização penetraram e invadiram todos os espaços do planeta (MACHADO, 2007:32-33).

Assim, a utilização das novas tecnologias por parte da arte faz crescer a importância de que os artistas sejam críticos a respeito do discurso global e reproduzam também as estéticas que perifericamente ainda existem. 


\section{Algumas referências críticas sobre a arte das NTC e as fronteiras}

Explicaremos aqui algumas considerações sobre as referências incluídas no corpo do texto e como elas estão conectadas com as propostas próprias desenvolvidas durante o tempo do mestrado.

A respeito dos trabalhos de Ostojic, podemos comparar as peças da artista com a experimentação feita em Cicatrizando (ver proposta 3.1 do capítulo III).

Tanto que em Cicatrizando a ação se baseia na exposição da imagem de uma mulher nua às intervenções feitas pelos participantes através da Internet, em Looking for a Husband with a EU Passport desprendeu-se uma ação similar em que o corpo nu da artista é modificado pelas intervenções espontâneas dos internautas.

Essa intervenção não calculada em Ostojic surge como se tratasse de uma ação de vandalismo, expandindo a proposta de procura de um marido pela exibição da imagem da artista na Internet (ver anexo 1).

Nos dois trabalhos é o discurso pessoal dos participantes que intervem nas imagens da mulher nua. São as referências pessoais frente ao corpo nu feminino que se misturam numa imagem só e que se aproveitam da iniciativa das artistas para, a partir delas, conseguirem se manifestar.

Em segundo lugar, no momento da elaboração do meu trabalho próprio e homônimo Passport (ver a proposta 3.2 do Capítulo III) a referência de Kulunčić era desconhecida.

O meu próprio trabalho percebia ser pertinente trazer a discussão do cruzamento de fronteiras ao contexto latino-americano. Isso permitiu expor a desigualdade existente dentro da América Latina, deixando como seus representantes países como a Colômbia e Cuba, e a relação que os mesmos têm em comparação com a posse de passaportes de outras regiões do planeta.

O trabalho de Kulunčić aponta para uma perspectiva mais geral em que a discussão latino-americana se perde, sendo que isto no meu trabalho é o eixo.

O trabalho da artista da Servia aponta apara a obtenção de dados estatísticos, ricos para interpretações quantitativas. O nosso, quer abrir a discussão em termos qualitativos. Nossa proposta pretende ser impactante ao oferecer um passaporte falsificado como produto de uma votação na Internet. É após esse estímulo que se abre o espaço para que os participantes comentem livremente sobre a problemática.

Por último em BorderXing as fronteiras da Europa são amplamente exploradas, contrapondo ao trabalho Coyote (ver item 3.3 do capítulo III), que traz novamente a 
discussão ao âmbito latino-americano, indagando sobre o atravessamento da fronteira México-Estados Unidos.

Em BorderXing o casal Bunting-Brandon se oferece como os primeiros exploradores para cruzar diversas fronteiras, já em Coyote são os imigrantes ilegais que constroem o manual para cruzar a fronteira México-Estados Unidos. Percebe-se que o risco tem sido assumido e superado pelo saber popular que se compila nas 25 entrevistas feitas com imigrantes em Nova lorque.

Em BorderXing os artistas europeus se oferecem como guias "legais" de futuros imigrantes ilegais.

Coyote é um manual que está mais perto do romance, mas que contém informações pertinentes e está publicamente exposto na Internet. BorderXing é uma proposta em que os artistas devem decidir anteriormente se a informação deve ser proporcionada ao participante. 


\section{A imagem fotográfica}

Nesta última consideração refletiremos brevemente sobre o uso feito das diversas aproximações à imagem fotográfica durante os trabalhos práticos desenvolvidos.

A perda da aura da imagem fotográfica que a acompanha desde sua aparição, se radicalizou com a mídia digital (SOULAGES, 2008). A perda de seu caráter sagrado a levou a participar de experimentações como a criação em rede das dimensões virtuais, nas que perdeu seus limites, se fusionando com outras manifestações e linguagens. Esta imagem fotográfica tornou-se uma "entre-imagem" (BELLOUR, 1997), uma "imagem mestiça" (MACHADO, 2007) ou "imagem expandida" (FERNÁNDEZ apud MACHADO, 2007). Enfim uma imagem "hipermediática" (ASCOTT, 2003).

No work in progress desenvolvido durante o Mestrado, a imagem fotográfica foi a primeira justificativa usada para favorecer a aproximação dos participantes às obras. Através do uso da fotografia prevíamos leituras no social, como foi o caso de Cicatrizando (item 3.1), em que o hipertexto criado em cadeia deixava transparecer os discursos pessoais. Assim, a proposta de Living Cemetery (item 3.1) radicalizou ainda mais o uso da fotografia como uma metáfora do estado pessoal dos participantes.

Paulatinamente, dirigimos a atenção a propostas de releitura do uso da imagem fotográfica no contexto virtual, como, por exemplo, em Desaparecidos (item 3.1). Nele também se abre a possibilidade à participação do espectador, mas nele é mais importante a apropriação e nova contextualização das imagens fotográficas trazidas no uso comum da Internet direcionado à arte.

Usamos também a imagem fotográfica como uma ação paralela em performances virtuais como OVO e Passport (item 3.2). Neles se evidenciava, como na perda da imagem fotográfica em ambientes virtuais, a emergência da pronunciação de discursos que usavam a fotografia sem que ela fosse necessariamente o eixo principal. Fundia-se assim nossa apropriação da fotografia com outras mídias, como o texto (Passport) ou o vídeo (OVO).

Finalmente, todo esse processo de criação crítico até mesmo com a mídia, permitiu-nos fugir da referência próxima à imagem fotográfica, elaborando, assim, experiências como Coyote e Caloto (item 3.3). Nessas experimentações, mesmo tendo a fotografia como recurso principal, se incorpora outras questões que chamam atenção tais como a autoria, o papel crítico e a função social da arte. 
Posteriormente, durante a proposta Sammlung, desenvolvida em KHM, Colônia, Alemanha, usamos a discussão sobre a web e arte, nos valendo agora de imagens fotográficas obtidas da web. As fotos da tela permitiram criar outras realidades como se essas fotos fossem uma nova maneira de retratar a realidade virtual.

Igualmente, em Lost Memories, também desenvolvida em KHM, a criação colaborativa é feita graças as imagens da vida da Taíssa na Alemanha, mas também a ação colaborativa é levada a um segundo momento, quando a intervenção dos interatores no website faz que a peça aconteça. $O$ trabalho se baseia no uso cotidiano da fotografia como memória e neste caso são as memórias da Taíssa em imagens as que compõem toda a poética.

Finalmente, em Holograms of Deportation são extraídas da Internet imagens de pessoas que tem sido deportadas que são posteriormente impressas em dot matrix holograms que são deixados de volta em Berlim durante uma performance.

Assim, é a linguagem fotográfica que tem sido discutida durante as experimentações desenvolvidas. Foram as mudanças sofridas pela imagem fotográfica que nos levaram a considerar novas aproximações aos participantes e assim, experimentou-se, então, com os diversos limites da linguagem fotográfica em criações colaborativas. A imagem fotográfica nos ambientes virtuais como a Internet facilitou o fortalecimento de uma proposta pessoal a respeito da arte multimídia.

A fotografia foi assim a companheira deste percurso, junto com a constante procura por incluir o interator nas diversas propostas desenvolvidas durante o Mestrado. 


\section{Relação de Figuras}

Figura 1. OSTOJIC, Tanja. Looking for a Husband with an EU Passport. Disponível em: <http://damp.nsk.hr/arhiva/vol1/1126/7327/artefact.mi2.hr/ a01/lang en/art ostojic en.h tm>. Acesso em: 21 nov. 2009.

Figura 2. OSTOJIC, Tanja. Crossing. Disponível em: <http://transitland.eu/video/\&videolD=66>. Acesso em: 21 nov. 2009.

Figura 3. KULUNCIC, Andreja. Passport. Disponível em: <http://embryo.inet.hr/passport>. Acesso em: 21 nov. 2009.

Figura 4. BRANDON, Kyle e BUNTING, Heath. BorderXing. Disponível em: <http://www.irational.org/borderxing>. Acesso em: 21 nov. 2009.

Figura 5. TACCA, Fernando. (2001). Big Brother. Disponível em: < http://www.studium.iar.unicamp.br/bigbrother/index.html>. Acesso em: 30 jul. 2008.

Figura 6. GERMANO, Nardo (2001-2006). Doe seu Rosto (2003-2004). Disponível em: <http://www.nardogermano.com/>. Acesso em: 30 jul. 2008.

Figura 7. GERMANO, Nardo (2006) Andromaquia (2004-2006). Disponível em: <http://www.nardogermano.com/>. Acesso em: 30 jul. 2008.

Figura 8. VELÁSQUEZ, Fernando. (2003) O Colecionador de Espíritos. Disponível em: <www.blogart.com/colecionador>. Acesso em: 30 jul. 2008.

Figura 9. GOIFMAN, Kiko, MULLER, Jurandir (2002) Cronofagia., In: NUNEZ, Fábio Oliveira (2002). Cronofagia. Disponível em: $<$ http://www.fabiofon.com/webartenobrasil/site cronofagia.html>. Acesso em: 30 jul. 2008.

Figura 10. SANDOVAL, Claudia (2008). Cicatrizando. Disponível em:, <http://www.claudiasandoval.com.br/scarring.html>. Acesso em: 24 mar. 2009. 
Figura 11. SANDOVAL, Claudia (2008). Living Cemetery. Disponível em: <http:// www.claudiasandoval.com.br/livingcemetery.html>. Acesso em: 10 out. 2008.

Figura 12. SANDOVAL, Claudia (2008). Imagens do trabalho Desaparecidos. Disponível em: <http://claudiasandoval.com.br/desaparecidos.html/>. Acesso em 18 ago. 2009.

Figura 13. SANDOVAL, Claudia (2008). Imagens do site Passport. Disponível em: <http://claudiasandoval.com.br/passport.html/>. Acesso em: 03 abr. 2009.

Figura 14. SANDOVAL, Claudia (2009). Imagens do site OVO. Disponível em: <http://claudiasandoval.com.br/ovo.html/>. Acesso em: 03 abr. 2009.

Figura 15. SANDOVAL, Claudia (2009). Imagens do site Coyote. Disponível em: <http://www.claudiasandoval.com.br/coyote.html>]. Acesso em: 24 fev. 2010.

Figura 16. SANDOVAL, Claudia (2009). Imagens do site Caloto. Disponível em: <http://www.calotocauca27.wordpress.com/>. Acesso em: 24 fev. 2010.

Figura 17. SANDOVAL, Claudia (2010). Imagens do site Sammlung, Disponível em: <http://kah-bonn.co.de/>. Acesso em: 23 jul. 2010.

Figura 18. SANDOVAL, Claudia (2010). Imagens do site Lost Memories. Disponível em: <http://www.claudiasandoval.com.br/lostmemories.html>. Acesso em: 23 jul. 2010.

Figura 19. SANDOVAL, Claudia (2010). Imagens da performance no site Lost Memories em KHM, Colônia, Alemanha.

Figura 20. SANDOVAL, Claudia (2010). Retratos das pessoas deportadas usadas para a criação de Dot Matrix Holograms. Disponível em: <http://www.claudiasandoval.com.br/hologramsofdeportation.html>. Acesso em 23 jul. 2010. 
Figura 21. SANDOVAL, Claudia (2010). Documentação dos 3 Dot Matrix Holograms deixados sobre as paredes de Berlim. Disponível em: <http://www.claudiasandoval.com.br/hologramsofdeportation.html>. Acesso em 23 jul. 2010.

\section{Referências Bibliograficas}

ASCOTT, Roy. (2003). Telematic Embrance: Visionary theories of art, technology, and consciousness. Califórnia/Berkeley/Los Angeles: University of California Press. Berkeley and Los Angeles. Tradução nossa.

BEIGUELMAN, Giselle. (2008). F for Fake 2.0. Disponível em: <[http://pphp.uol.com.br/tropico/html/textos/2491,1.shl>. Acesso em: 01 abr. 2009.

BARTHES, Roland. (1968) A Morte do Autor. Disponível em: $<$ http://www.facom.ufba.br/sala de aula/sala2/barthes1.html>. Acesso em 26 nov. 2008.

.BARTHES, Roland. [(1970) (1992)]. S/Z: Uma Análise da Novela Sarrasine de Honoré de Balzac. Tradução de Léa Novaes. Rio de Janeiro: Editora Nova Fronteira. Tradução de Léa Novaes. 1992.

BELLOUR, Raymond. (1997)."Entre-Imagens". In Entre-Imagens - Foto, Cinema, Vídeo. São Paulo: Editora Papirus, p.10-19. (1 ed. francesa em 1990).

COMPAGNON, Antoine. (2001). O Demônio da Teoria: Literatura e Senso Comum. Tradução Cleonice Paes Barreto Mourão e Consuelo Fortes Santiago. Belo Horizonte: Editora UFMG.

COSTA, Mario. (1995). O Sublime Tecnológico. Tradução Dion Davi Macedo. São Paulo: Editora Experimento. Tradução Dion Davi Macedo.

COUCHOT, Edmond. (1993). "Da Representação à Simulação: Evolução das Técnicas e das Artes da Figuração" In: Imagem-Máquina. A Era das Tecnologias do Virtual. Tradução Rogério Luz. São Paulo: Editora 34, p.37-48 
ECO, Umberto. (1969). Obra Aberta: forma e indeterminação nas poéticas contemporâneas. São Paulo, Editora Perspectiva.

FOUCAULT, Michel. [(1969) (1992)] O Que é um Autor?. Rio de Janeiro: Passagens. 1992.

GARCIA DOS SANTOS, Laymert. (2003). Politizar as Novas Tecnologias: O Impacto Sócio-Técnico da Informação Digital e Genética. Rio de Janeiro: Editora 34.

GERMANO, Nardo. (2007). Autor-retrato Coletivo Poéticas de Abertura ao Espectador na Desconstrução de uma Identidade Coletiva. Dissertação de Mestrado. São Paulo: Universidade de São Paulo.SP

GERMANO, Nardo. (2006) Andromaquia (2004-2006). Disponível em: <http://www.nardogermano.com/>. Acesso em: 30 jul. 2008.

GERMANO, Nardo. (2006) Doe seu Rosto (2001-2006). Disponível em: <http://www.nardogermano.com/>. Acesso em: 30 jul. 2008.

GIANNETTI, Claudia. (2006). Estética Digital, Sintopia da arte, a ciência e a tecnologia. Tradução Maria Angélica Melendi. Belo Horizonte: Editora c/Arte. Tradução Maria Angélica Melendi.

IBGE. Disponível em: <http://www.cabecadecuia.com/noticias/29788/ibge-populacaobrasileira-e-de-1896-milhoes-.html>. Acesso em: em 07 out. 2009.

IBOPE.

Disponível

em:

<http://www.ibope.com.br/calandraWeb/servlet/CalandraRedirect?temp=6\&proj=PortallB OPE\&pub=T\&nome=impressao\&db=caldb\&docid=8411DFBF6DFF8E02832575EB004E D394>. Acesso em: 07 out. 2009.

JAUSS, Hans Robert. [(1970) (1993)]. A Literatura como Provocação. História da Literatura como Provocação Literária. Tradução Teresa Cruz. Lisboa: Editora Vega. Tradução Teresa Cruz, Vega. 1993. 
JIMENEZ, Marc. (1998). O que é Estética? Tradução Fulvia M.L. Moretto. São Leopoldo/RS: Editora Unisinos. Tradução Fulvia M.L. Moretto.

KALCIC, Silva. (2009). Passport. Disponível em: <http://artefact.mi2.hr/ a01/lang en/art kuluncic pass en.htm>. Acesso em: 14 abr. 2009.

LANDOW, George P. (1992) Hypertext. The convergence of contemporary critical theory and technology. Baltimore: The Johns Hopkins University Press. Tradução nossa.

LAURENTIZ, Silvia. (2004) Padrões Emergentes e/ou Valores Estéticos. Disponível em: <http://www.cap.eca.usp.br/silvia/hi/Padres_emergentes.pdf>. Acesso em: 30 jul. 2008.

LAURENTIZ, Silvia. (2006). A Subjetividade em Rede: Um Sistema Complexo. Disponível em: <http://www.cap.eca.usp.br/silvia/hi/subjetividade_Laurentiz.pdf>. Acesso em: 30 jul. 2008.

LEÃO, Lucia. (2001). O labirinto da Hipermídia: Arquitetura e Navegação no Ciberespaço. São Paulo: Editora lluminuras.

LEMOS, André. (2002). A Arte Da Vida. Diários Pessoais e Webcams na Internet. In Cultura da Rede. Revista Comunicação e Linguagem, Lisboa. Disponível em: $<$ http://www.andrelemos.info/artigos/arte\%20da\%20vida.htm>. Acesso em: 01 mar. 2009.

LÉVY, Pierre (1993). Cibercultura. Tradução Carlos Irineu da Costa. São Paulo: Editora 34. Tradução Carlos Irineu da Costa. (1 ed francesa 1997)

MACHADO, Arlindo. (2007). Arte e Mídia. Rio de Janeiro: Jorge Zahar Editor Ltda.

MOREIRA, Ruy. (2007). Da Região à Rede e ao Lugar: a Nova Realidade e o Novo Olhar Geográfico Sobre o Mundo. , Disponível em: <http://www.uff.br/etc/UPLOADs/etc\%202007 1 3.pdf>. Acesso em 05 maio 2009. 
MUNTADAS, Antoni. (2007). "Visiting Professor at the MIT Visual Arts Program". In: FRANK, Andrea (Org.). Visions. MIT Interviews. Organizadora: Andrea Frank, p.120123. Tradução Nossa.

MURRAY, Janet H. (2001). Hamlet no Holodeck. O futuro da narrativa no ciberespaço. Tradução Elissa Khoury Daher e Marcelo Fernandez Cuzziol. São Paulo: Fundação Editora da Unesp. (1. ed inglesa. 1997).

NUNEZ, Fábio Oliveira. (2002). Cronofagia. Disponível em: $<$ http://www.fabiofon.com/webartenobrasil/site cronofagia.html>. Acesso em: 30 jul. 2008.

NUNEZ, Fábio Oliveira. (2002a). Sobre Tempo e Morte na Rede. Disponível em: <http://www.fabiofon.com/webartenobrasil/texto tempo.html>. Acesso em: 30 jul. 2008.

OSTOJIC, Tanja. (2009). Integration Impossible? The Politics of Migration in the Artwork of Tanja Ostojic. Berlim: Argobooks. Berlin.

PARRET, Herman. (s.d). A estética da Comunicação. Além da Pragmática. Tradução Roberta Pires de Oliveira. Campinas: Editora da Universidade Estadual de Campinas. Tradução Roberta Pires de Oliveira. (1. ed inglesa. 1997).

PRADO, Gilbertto. (1997). Dispositivos Interativos: Imagens em Redes Telemáticas. Disponível em:

<http://www.cap.eca.usp.br/wawrwt/textos/gilbertto6.html>. Acesso em: 30 jul. 2008.

SAID, Edward. (1999). Cultura e Imperialismo. Rio de Janeiro: Companhia das Letras.

SANDOVAL, Claudia (2008). Cicatrizando. Disponível em: <http://www.claudiasandoval.com.br/scarring.html>. Acesso em: 24 mar. 2009.

SANDOVAL, Claudia (2008a). Living Cemetery. Disponível em: <http:// www.claudiasandoval.com.br/livingcemetery.html>. Acesso em: 10 out. 2008. 
SANTOS, Milton. (2000). Por Uma Outra Globalização. Do Pensamento Único à Consciência Universal. Rio de Janeiro. Editora. Record.

SCHNEIDER, Florian. (2002). Reverse Authentification. Disponível em: <http://www.tate.org.uk/intermediaart/entry15468.shtm>. Acesso em: 07 out. 2009. Tradução nossa.

SOULAGES, François. (2008). A Revolução Paradigmática da Fotografia Numérica. Tradução de Laurita Salles. São Paulo, Revista ARS 9. Escola de Comunicações e Artes da Universidade de São Paulo. Tradução de Laurita Salles. Revisão Técnica de Gilbertto Prado.

TACCA, Fernando. (2001). Big Brother. Disponível em: <http://www.studium.iar.unicamp.br/bigbrother/index.html>. Acesso em: 30/ jul. 2008.

TRIVINHO, Eugênio. (2007). A Dromocracia Cibercultural. Lógica da Vida Humana na Civilização Mediática Avanzada. São Paulo: Editora Paulus.

ZORAN, Eric. (2002). Personal Space - Public Body. Disponível em: <http://www.cac.org.mk/capital/ostojic>. Acesso em: 07 out. 20/10/09. Tradução nossa. 
Anexo 1
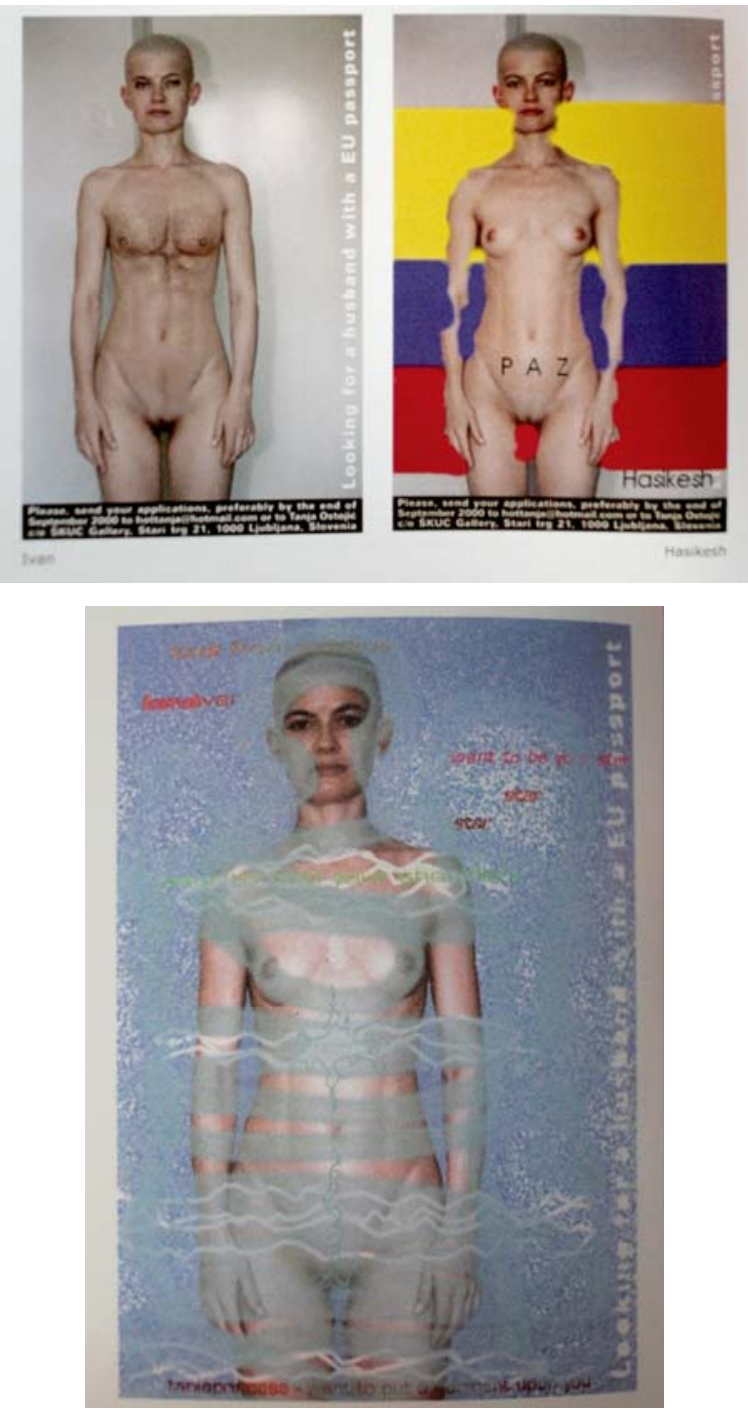
Imagens surgidas paralelamente ao trabalho Looking for a Husband with a EU Passport de Tanja Ostojic. Imagens tomadas da publicação Integration Impossible? The Politics of Migration in the Artwork of Tanja Ostojic. Argobooks. Berlim. 2009. 